\title{
Yellowstone Lake Ecosystem Restoration: A Case Study for Invasive Fish Management
}

\author{
Todd M. Koel ${ }^{1, *}{ }^{\mathbb{D}}$, Jeffery L. Arnold ${ }^{1,+}{ }^{,}$Patricia E. Bigelow ${ }^{1}$, Travis O. Brenden ${ }^{2}$,
} Jeffery D. Davis ${ }^{3}$, Colleen R. Detjens ${ }^{1}$, Philip D. Doepke ${ }^{1}$, Brian D. Ertel ${ }^{1}$, Hayley C. Glassic ${ }^{4}$ (D) Robert E. Gresswell ${ }^{5}$, Christopher S. Guy ${ }^{6}$, Drew J. MacDonald ${ }^{7}$, Michael E. Ruhl ${ }^{7, \ddagger}$, Todd J. Stuth ${ }^{8}$, David P. Sweet ${ }^{9}$, John M. Syslo ${ }^{4, \$}$, Nathan A. Thomas ${ }^{1}$, Lusha M. Tronstad ${ }^{10}$ (1), Patrick J. White ${ }^{1}$ and Alexander V. Zale ${ }^{6}$

1 U.S. National Park Service, Yellowstone Center for Resources, Native Fish Conservation Program, P.O. Box 168, Yellowstone National Park, WY 82190, USA; jeff_arnold@nps.gov (J.L.A.); pat_bigelow@nps.gov (P.E.B.); colleen_detjens@nps.gov (C.R.D.); philip_doepke@nps.gov (P.D.D.); brian_ertel@nps.gov (B.D.E.); nathan_thomas@nps.gov (N.A.T.); pj_white@nps.gov (P.J.W.)

2 Quantitative Fisheries Center, Michigan State University, 375 Wilson Road, East Lansing, MI 48824, USA; brenden@anr.msu.edu

3 Yellowstone Forever, P.O. Box 117, Yellowstone National Park, WY 82190, USA; jddavis@yellowstone.org

4 Montana Cooperative Fishery Research Unit, Department of Ecology, Montana State University, P.O. Box 173460, Bozeman, MT 59717, USA; hcg0509@gmail.com (H.C.G.); john.syslo@noaa.gov (J.M.S.)

5 U.S. Geological Survey, Northern Rocky Mountain Science Center, 2327 University Way, Bozeman, MT 59715, USA; bgresswell@usgs.gov

6 U.S. Geological Survey, Montana Cooperative Fishery Research Unit, Department of Ecology, Montana State University, MSU-P.O. Box 173460, Bozeman, MT 59717-3460, USA; cguy@montana.edu (C.S.G.); zale@montana.edu (A.V.Z.)

7 Montana Institute on Ecosystems, Montana State University, MSU-P.O. Box 173490, Bozeman, MT 59717-3490, USA; drew_macdonald@nps.gov (D.J.M.); michael.ruhl@state.nm.us (M.E.R.)

8 Hickey Brothers Research, LLC, 4083 Glidden Drive, Sturgeon Bay, WI 54235, USA; stuthfishing@charter.net

9 Wyoming Council of Trout Unlimited, P.O. Box 3008, Cody, WY 82414, USA; davidps992@gmail.com

10 Wyoming Natural Diversity Database, University of Wyoming, 1000 East University Avenue, Department 3381, Laramie, WY 82071, USA; tronstad@uwyo.edu

* Correspondence: todd_koel@nps.gov; Tel.: +1-307-344-2281

+ Current affiliation: U.S. National Park Service, Science and Resource Management, Glen Canyon National Recreation Area \& Rainbow Bridge National Monument, P.O. Box 1507, Page, AZ 86040, USA.

$\ddagger$ Current affiliation: New Mexico Department of Game \& Fish, Fisheries Management Division, 1 Wildlife Way, Santa Fe, NM 87507, USA.

$\S$ Current affiliation: NOAA Fisheries, Pacific Islands Fisheries Science Center, 1845 Wasp Blvd., Bldg. 176, Honolulu, HI 96818, USA.

Received: 17 May 2020; Accepted: 9 June 2020; Published: 12 June 2020

Abstract: Invasive predatory lake trout Salvelinus namaycush were discovered in Yellowstone Lake in 1994 and caused a precipitous decrease in abundance of native Yellowstone cutthroat trout Oncorhynchus clarkii bouvieri. Suppression efforts (primarily gillnetting) initiated in 1995 did not curtail lake trout population growth or lakewide expansion. An adaptive management strategy was developed in 2010 that specified desired conditions indicative of ecosystem recovery. Population modeling was used to estimate effects of suppression efforts on the lake trout and establish effort benchmarks to achieve negative population growth $(\lambda<1)$. Partnerships enhanced funding support, and a scientific review panel provided guidance to increase suppression gillnetting effort to $>46,800100$-m net nights; this effort level was achieved in 2012 and led to a reduction in lake trout biomass. Total lake trout biomass declined from 432,017 kg in 2012 to $196,675 \mathrm{~kg}$ in 2019, primarily because of a 79\% reduction in adults. Total abundance declined from 925,208 in 2012 to 673,983 in 2019 but was highly variable because of recruitment of age-2 fish. Overall, 3.35 million 
lake trout were killed by suppression efforts from 1995 to 2019. Cutthroat trout abundance remained below target levels, but relative condition increased, large individuals ( $>400 \mathrm{~mm}$ ) became more abundant, and individual weights doubled, probably because of reduced density. Continued actions to suppress lake trout will facilitate further recovery of the cutthroat trout population and integrity of the Yellowstone Lake ecosystem.

Keywords: adaptive management; cutthroat trout; ecosystem restoration; nonnative fish suppression; national park; lake trout; native species recovery; Oncorhynchus; predatory fish invasion; Salvelinus; trophic cascade; wilderness preserve

\section{Introduction}

Apex predatory fishes introduced to freshwaters of the United States Intermountain West are invasive because they can spread within lakes or through interconnected river networks and pose a high risk to native species [1,2]. Native fish species richness in this region is naturally low and made up largely of non-predatory guilds [3]. Although introduced predatory fish often provide enhanced sport fishing opportunities [4], they prey upon vulnerable natives resulting in reductions of native species abundance or complete extirpation [5-7]. Predation losses in some areas have contributed to listing of native fishes as threatened or endangered under the Endangered Species Act (ESA) [8-10]. Introduction of a novel apex predator to a freshwater ecosystem may also result in cascading changes whereby inverse patterns in abundance, productivity, or biomass of populations or communities emerge across links in the aquatic food web [1,11]. Given that invasive predatory fishes have been introduced to all large lakes and rivers in the Western United States [12-14], mitigating negative effects from these introductions is a widespread problem faced by resource managers.

Because complete eradication or containment is generally not feasible in large aquatic systems [15,16], programs have been implemented to suppress invasive fish populations and relieve predation pressure on sympatric native species or desired, introduced sportfish populations [17-19]. Suppression programs for other waters are being contemplated [20-22]. However, proposed suppression programs are often challenged by constituents of the popular nonnative fisheries that have become established $[23,24]$ or are complicated by presence of ESA-listed species that might be harmed by the suppression actions [25]. Lack of species-selective removal methods [15] and uncertainty in outcomes of the removal programs are common obstacles. In addition, because complete, system-wide eradication of an invasive fish is probably unattainable, a long-term commitment is required to maintain suppression actions (and funding to support them) to ensure the invasive population does not rebound [26].

The natural variation in abiotic conditions and complexity of biotic interactions within large aquatic ecosystems make outcomes of conservation actions to suppress invasive fish uncertain. These uncertainties may be accounted for, however, if an active adaptive management strategy is adopted [27,28]. In taking this approach, conservation actions are treated as deliberate, large-scale experimental manipulations and the results of these actions increase knowledge about the system and decrease uncertainty in management outcomes. Alternative approaches are incorporated into the monitoring design and evaluated as experimental treatments with expectations (hypotheses) in outcomes [29-31]. Future management decisions are adjusted based on new knowledge about the resource being managed [32]. Because introduced apex predatory fish directly result in loss of prey fish and indirectly force altered, cascading interactions throughout food webs [33], their removal is predicted to allow recovery of the prey species and a return of food-web interactions and other ecosystem services to their natural state [34]. An active adaptive management approach allows for incorporation of the response uncertainties within these complex aquatic ecosystems. 
Further adding to the complexities of predicting ecological responses to invasive fish removal are anthropogenic alterations within watersheds. Agriculture, cattle grazing, mining, power generation, timber harvest, and urbanization are common disturbances in the United States Intermountain West. Multiple, interacting invaders may also occur and contribute to altered ecological interactions and the complexity of responses to management actions [35,36]. Understanding the effects of predatory fish introduction and assessing outcomes that are specifically driven by suppression actions are challenging because of these concurrent, confounding factors. The majority of these challenges are minimal within large federally-protected wildlands in the United States, including national parks and wilderness areas, where habitats are strictly preserved to support fish life history, diversity, population persistence, intact food webs, and natural ecological function. Ecological recovery of populations is more likely in areas with relatively little anthropogenic disturbance and few other invaders [36] than where confounding anthropogenic factors exist. Studies assessing the long-term benefits of invasive, predatory fish suppression in protected natural areas may therefore be more informative than those in more complex, anthropogenically confounded systems elsewhere.

\section{Study Area and Focal Species}

Yellowstone Lake is a large aquatic system on the Yellowstone Plateau (2357 $\mathrm{m}$ in elevation) with a highly protected watershed $\left(>3200 \mathrm{~km}^{2}\right)$ located within Yellowstone National Park and the Bridger-Teton Wilderness of Wyoming (Figure 1, Video S1). As such, invasive fish are the only large-scale impact sensu [37] on the lake; its waters remain physically and chemically pristine. Yellowstone Lake is the largest alpine (above $2000 \mathrm{~m}$ ) lake in North America and has a surface area of 34,000 ha, $239 \mathrm{~km}$ of shoreline, mean depth of $48 \mathrm{~m}$, maximum depth of $137 \mathrm{~m}$, and volume of $1.5 \times 10^{10} \mathrm{~m}^{3}[38,39]$. Powerboat access is limited to only two locations, at Bridge Bay and Grant marinas, and most of the shoreline lies in protected (federally proposed) wilderness. Thermal structure of the lake is typically unstable with a weak and variable thermocline at a depth of $12-15 \mathrm{~m}$ during July to September (Figure A1). Surface water temperatures rarely exceed $18^{\circ} \mathrm{C}[40,41]$. Specific conductance is typically $<100 \mu \mathrm{S} / \mathrm{cm}$ [42]. The lake freezes over by late December and can remain frozen until late May (Figure 2) or early June. In winter, ice about $1 \mathrm{~m}$ thick under deep $(>1 \mathrm{~m})$ snow covers much of the lake except where shallow water covers active hot springs. Roads are not cleared of snow, and access to the lake during winter is restricted to over-snow vehicles. These logistical constraints and safety risks preclude work during winter months.

The fish assemblage in Yellowstone Lake includes only two natives, Yellowstone cutthroat trout (see Table A1 for all scientific names) and the less abundant minnow, longnose dace. Ancestral Yellowstone cutthroat trout, hereafter cutthroat trout, are thought to have accessed the upper Yellowstone River and Yellowstone Lake from the upper Snake River via natural connections across the Continental Divide [43,44] following glacial recession about 14,000 years ago [45]. Cutthroat trout then evolved as the sole salmonid and dominant fish within the lake and its connected river network. During spring (May-July), cutthroat trout spawn in up to 68 tributaries around Yellowstone Lake, move downstream to spawn in the Yellowstone River below Fishing Bridge, or make long-distance spawning migrations upstream into the remote headwaters of the upper Yellowstone River [46]. Because of their lacustrine-adfluvial life history strategy $[40,47,48]$, they transport lake-derived nutrients into numerous tributary streams [49] where they are important prey for grizzly bears [50], black bears [51], and numerous avian predators [52,53]. Although some cutthroat trout fry may remain in the natal stream for 1-2 years, most move into Yellowstone Lake within several months of hatching. In the lake, juvenile cutthroat trout are pelagic and feed on zooplankton [54]. Adults occupy the epilimnion at depths $<20 \mathrm{~m}$ but are most frequently found in the littoral zone where they feed on benthic macroinvertebrates and zooplankton. Because cutthroat trout are commonly found in shallow waters of Yellowstone Lake, they are preferred prey of river otters [55], osprey, bald eagles, and several colonial waterbirds [41,56-58]. 


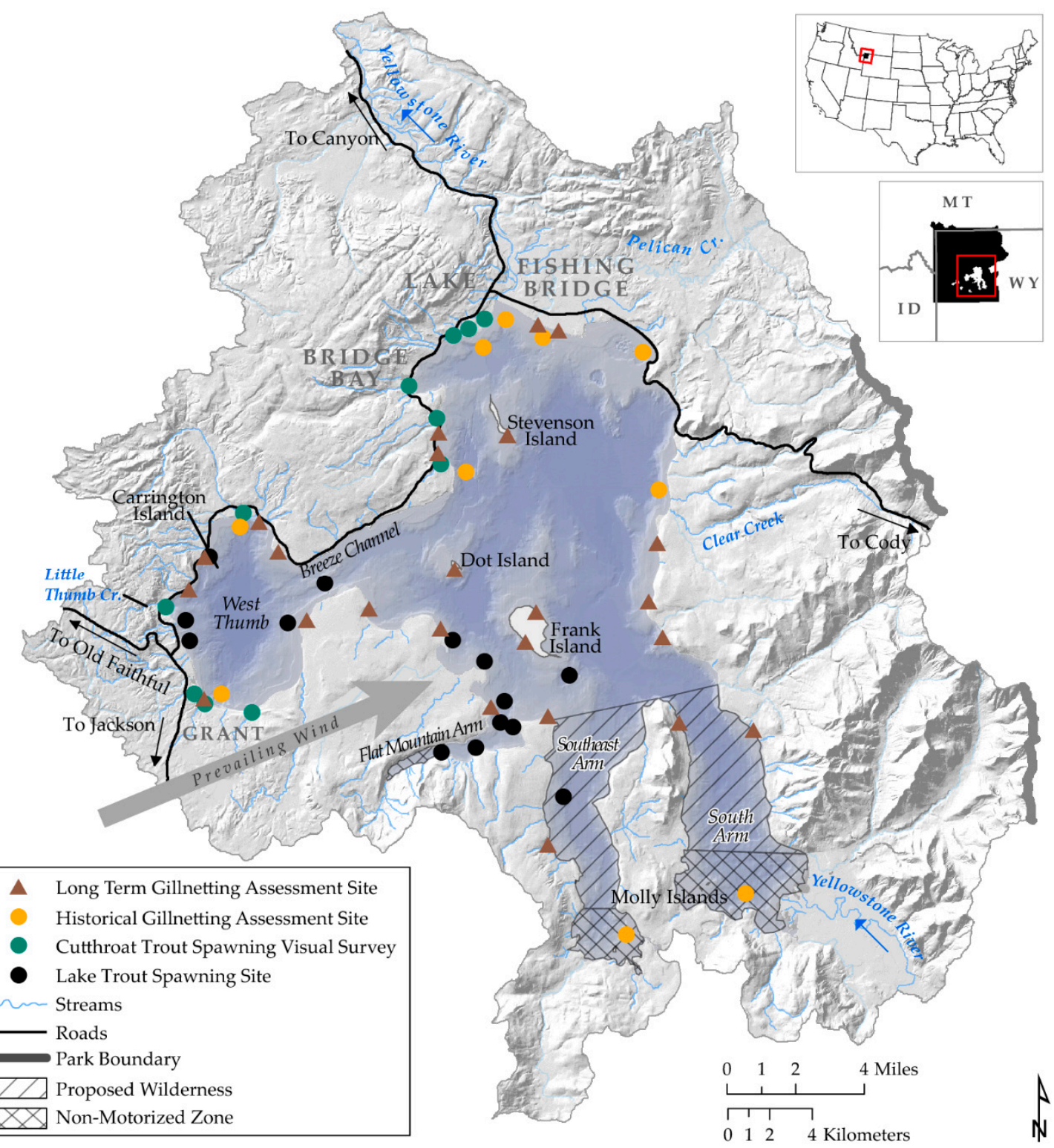

Figure 1. Yellowstone Lake within Yellowstone National Park in Northwestern Wyoming, USA, indicating locations of long-term gillnetting assessment sites for annual lake-wide monitoring of cutthroat trout and lake trout, historical gillnetting assessment sites that were sampled for cutthroat trout (prior to 2010), tributaries visually surveyed for spawning cutthroat trout each spring, and verified lake trout spawning sites [59]. Although 14 lake trout spawning sites are known in Yellowstone Lake, others probably exist [60]. Prevailing southwest $\left(247^{\circ}\right)$ winds and lake fetch during the autumn spawning period may preclude successful spawning along the eastern shore [61,62].

Along with their ecological importance, cutthroat trout are also historically significant. Early explorers of the Yellowstone Lake area noted their unique beauty and abundance. Soon after the establishment of Yellowstone National Park in 1872, cutthroat trout played an important role locally for subsistence, and nationally for recreation, as anglers were drawn from the Eastern United States for the angling experience [63,64]. Initial activities of the newly formed U.S. Commission on Fish and Fisheries focused on Yellowstone Lake. With the development of methods to propagate and move fish species, 310 million cutthroat trout eggs were shipped during 1901-1956 across the United States and elsewhere [65]. Other non-native fishes were introduced to Yellowstone Lake, presumably by anglers, including lake chub, longnose sucker, and redside shiner [65]. Although rarely 
studied, these fishes were new additions to the food web and likely altered the aquatic and terrestrial ecosystems by feeding on plankton and macroinvertebrates [54,66] and serving as prey for piscivorous birds [56,67] and mammals [55]. There was no evidence these fishes negatively affected the native cutthroat trout $[40,68,69]$. Yellowstone National Park prohibited stocking non-native fish into park waters as early as 1936 [70].

By the 1950s, following half a century of liberal angler harvest and egg collections by the U.S. Bureau of Sport Fisheries, abundance of the cutthroat trout population of Yellowstone Lake was declining and showing imminent signs of collapse [40]. Numbers of cutthroat trout migrating into tributary spawning streams were declining, and lakewide angler catch rates were low. A paradigm shift in National Park Service (NPS) management then occurred to one with an ecological basis [71] resulting in a redefinition of the role of cutthroat trout in Yellowstone Lake. Following restrictions on angler harvest and closure of the egg-collection operations, the population rebounded in the 1960 s and 1970s and became so abundant that $>70,000$ cutthroat trout were counted spawning in a single spawning tributary (Clear Creek; Figure 1) during the spring of 1979 [72]. Biologists estimated 3.5 million (95\% CI: 1.9-11.2 million) cutthroat trout (>350 mm total length) inhabited Yellowstone Lake at that time, and the consumers of these fish, such as bears, otters, ospreys, and bald eagles, were numerous near the lake. The ecosystem reflected its natural, pre-Euro-American condition [71].

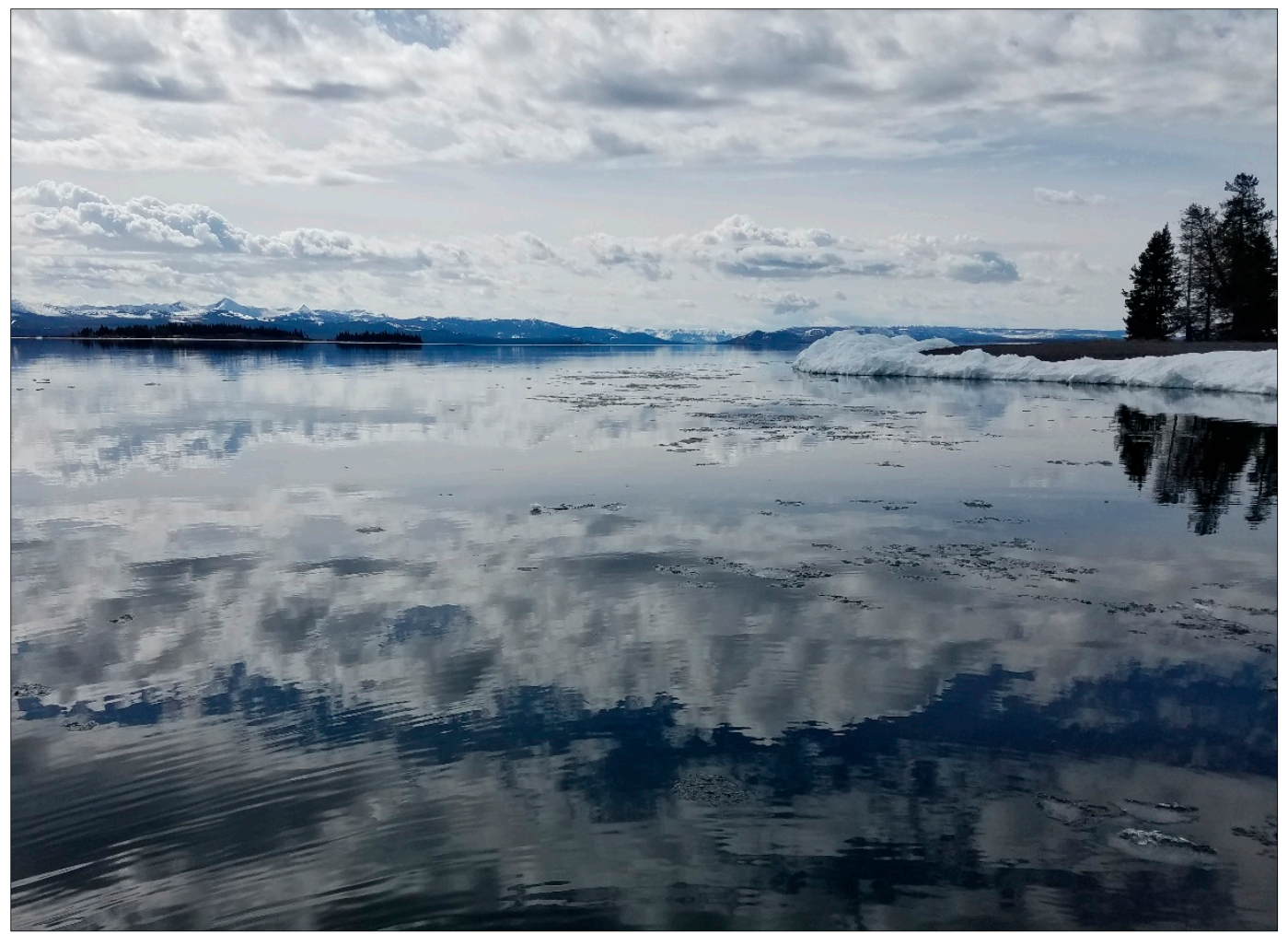

Figure 2. Yellowstone Lake in Yellowstone National Park on 26 May 2019. Yellowstone Lake is the largest alpine (above $2000 \mathrm{~m}$ ) lake in North America and has a surface area of 34,000 ha, $239 \mathrm{~km}$ of shoreline, mean depth of $48 \mathrm{~m}$, maximum depth of $137 \mathrm{~m}$, and volume of $1.5 \times 10^{10} \mathrm{~m}^{3}[38,39]$.

\section{Predatory Fish Invasion and Initial Management Response}

The perception of Yellowstone Lake as a secure refuge for cutthroat trout changed abruptly on 30 July 1994, when a nonnative lake trout was caught from the lake by an angler on a guided fishing trip [73]. Additional lake trout were caught soon afterwards causing grave concern, because their potential to negatively affect native trout had previously been well-documented in other large lakes in the Western United States (e.g., Lake Tahoe) [6,7]. An NPS press release dated 11 August 1994, described the discovery of lake trout in Yellowstone Lake, outlined ecological consequences that could 
result from establishment of this highly piscivorous, invasive fish species, and offered a US $\$ 10,000$ reward for information leading to the arrest and conviction of the person(s) responsible for illegally stocking the fish. The NPS immediately implemented a must-kill regulation to prevent angler-caught lake trout from being returned to Yellowstone Lake alive. An illegal stocking of lake trout was assumed because natural movement into Yellowstone Lake from waters of the upper Snake River (in which they had previously been established) was not thought possible [74]. Regardless of the mode of introduction, lake trout were present and were already well on their way to establishing themselves as a new apex predator in Yellowstone Lake.

The native range of lake trout in North America includes Alaska, Canada, the Great Lakes, and parts of New England [75]. In their native range, lake trout fill an important ecological niche as an apex predator in food webs of lakes [76] and support valuable fisheries [77]. Lake trout are a deep-water dwelling, cold-adapted $\left(<10^{\circ} \mathrm{C}\right)$ predatory species that do not serve as an ecological substitute for cutthroat trout in Yellowstone Lake. Lake trout spawn within the lake and do not use tributary streams, making them inaccessible to native piscivorous avian and terrestrial wildlife. Additionally, lake trout can be extremely long-lived (30+ years, if unexploited) [78], grow longer than any other charr, can weigh more than $27 \mathrm{~kg}$ [44], and are capable of capturing prey at least half their body length (Figure 3) [79]. Lake trout in Yellowstone Lake mature at an earlier age (males age 4) than other populations in the Western U.S., probably because of their fast growth rates [7]. Fecundity is high, with a 5-kg female capable of producing 6000-8000 eggs in a single spawning event $[79,80]$. In addition, the early life history (pre-recruit) survival of lake trout in Yellowstone Lake is estimated to be 4-6 times greater than in their native range (discussed below) [81].

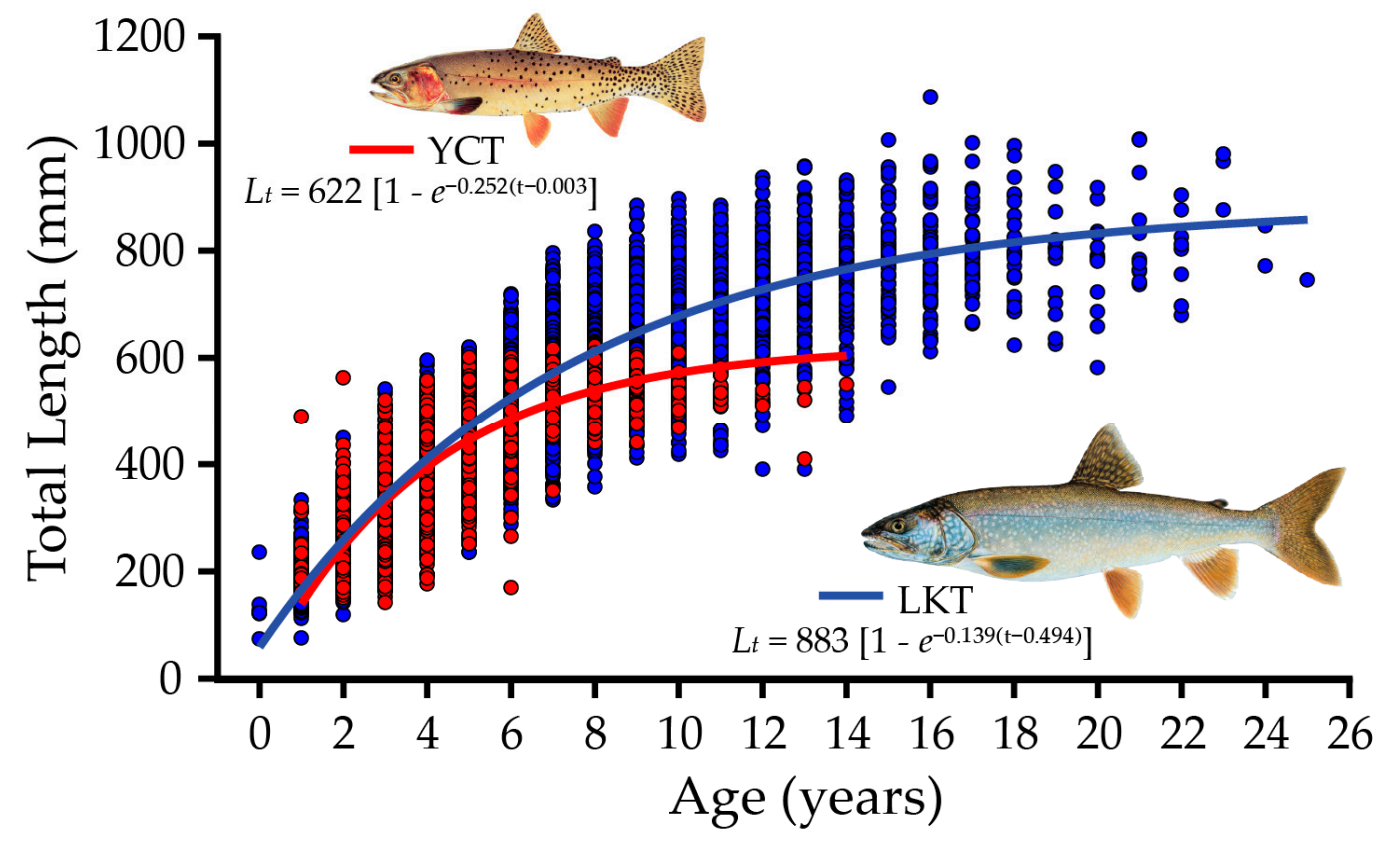

Figure 3. Total lengths-at-age $\left(L_{t}\right)$ of native cutthroat trout $(Y C T ; n=1350)$ and invasive lake trout $(\mathrm{LKT} ; \mathrm{n}=6387$ ) collected by gillnetting on Yellowstone Lake during 1998 to 2019, with von Bertalanffy growth functions. Asymptotic mean lengths of cutthroat trout and lake trout were $622 \mathrm{~mm}(95 \% \mathrm{CI}$ : 600-648) and $883 \mathrm{~mm}$ (95\% CI: 869-898), respectively. Cutthroat trout with a maximum age of 14 years had a mean predicted length of $604 \mathrm{~mm}$ and lake trout with a maximum age of 25 years had a mean predicted length of $854 \mathrm{~mm}$

The NPS convened a panel of experts from throughout the United States and Canada to assess the consequences of lake trout presence in Yellowstone Lake in 1995 [82]. At that time, in the absence of knowledge of the behavior and habits of lake trout in Yellowstone Lake, the primary recommendations of the science panel were to develop a program for limiting their expansion coupled with careful 
monitoring and application of adaptive management strategies [83]. The 1995 panel concluded that, despite a high level of uncertainty, the probability of eliminating lake trout was low and that the introduced predator would reduce the cutthroat trout population in Yellowstone Lake (Figure 4). At the same time, the group suggested that lake trout abundance could, with a high degree of probability, be limited by initiating an aggressive control program using gillnetting. Because complete eradication of lake trout was unlikely, a long-term commitment would be required to control lake trout abundance. It was agreed that the cutthroat trout population would decline even if lake trout could be suppressed, but a lake trout suppression program could reduce the expected loss of cutthroat trout by $50 \%$ or more. Most of the information needed to increase the effectiveness of initial control measures could be obtained from the control program itself, but some modification of the existing mid-September cutthroat trout gillnetting assessment program would be required to also evaluate changes in the lake trout population [83].

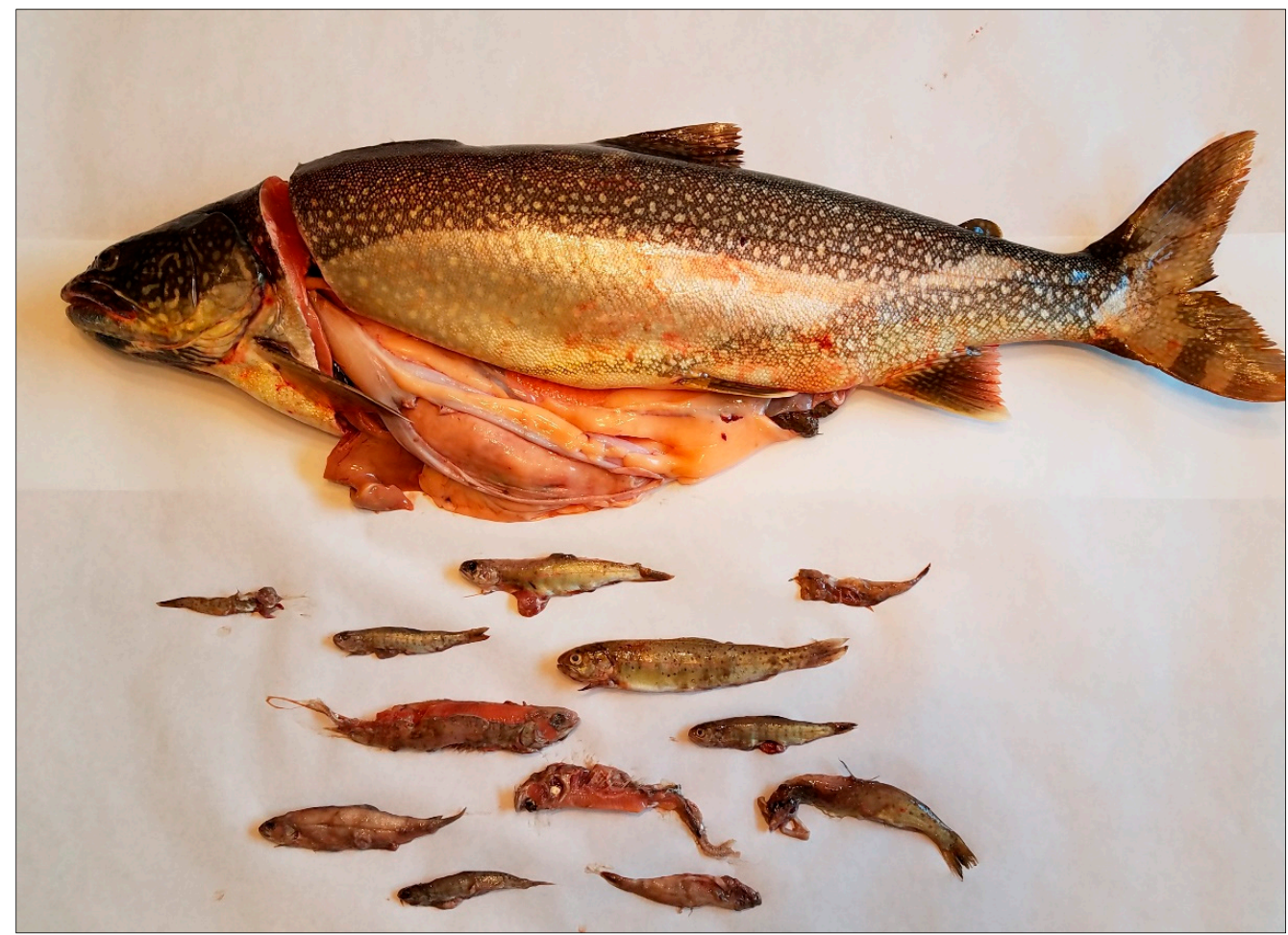

Figure 4. Twelve cutthroat trout from the stomach of a lake trout (approximately $3 \mathrm{~kg}$ ) gillnetted immediately following ice-off from Yellowstone Lake in May 2017. During 8 months of the year (mid-October through mid-June) there is no thermal cause for separation of lake trout from cutthroat trout. Predation pressure by lake trout under the ice, which has never been studied, is likely high.

Lake trout suppression began in 1995 primarily by control (targeted) gillnetting at depths $>20 \mathrm{~m}$ to avoid cutthroat trout, and secondarily by experimental (exploratory) gillnetting designed to gain information on lake trout distribution seasonally throughout the lake. By 1999, two key spawning areas in the West Thumb of Yellowstone Lake had been identified by telemetry-Carrington Island and Solution Hump-where high concentrations of lake trout occurred during autumn (Figure 1). By 1999, nearly 15,000 lake trout were killed by gillnetting, with progressively more netted each year despite limited NPS resources (Figure A3). Retrospective population modeling estimated that 10,000 or more lake trout were probably in Yellowstone Lake in 1994 when they were first discovered [79]. Several years of bioenergetics research provided estimates of lake trout predation on the cutthroat trout population $[79,84]$, and it became apparent that a dedicated program was required to curtail further lake trout population growth. However, enough funding to support such an effort had not been obtained. 
Yellowstone National Park biologists then successfully competed for and were awarded an NPS Natural Resource Management grant in 1999 specifically for the development of a lake trout suppression program in 1999-2001. The supplemental funding allowed hiring a seasonal NPS crew dedicated to suppressing lake trout. With these new resources and redirected park funds, the park developed a comprehensive program for suppression of lake trout that consisted of intensive control gillnetting, gillnetting for annual monitoring, and focused gill netting of spawning lake trout. This program resulted in the removal of more than 340,000 lake trout by 2008. However, as the enhanced suppression program continued, gillnet catch rates continued to increase, suggesting that lake trout population abundance was continuing to increase and the population was expanding spatially across Yellowstone Lake. In addition, long-term monitoring of the cutthroat trout population suggested a concurrent decline to levels lower than ever previously recorded [85]. After more than a decade of sustained lake trout gillnetting and no evidence of cutthroat trout recovery, a comprehensive scientific appraisal of the on-going program was warranted.

\section{Development of a Conservation Strategy that Embraces Uncertainty}

The lake trout-induced collapse of cutthroat trout became increasingly apparent to the public during the 2000s as angler catch rates declined severely on Yellowstone Lake and the Yellowstone River both upstream and downstream of the lake (Figure 1) [46,51]. The loss was particularly noteworthy because cutthroat trout were the only sport fish available to anglers in this ecosystem. The decline also affected backcountry outfitters and anglers seeking the migratory, spawning fish in distant reaches of the upper Yellowstone River south of Yellowstone Lake within the Bridger-Teton Wilderness of Wyoming [46]. In addition to the precipitous decline of cutthroat trout, the novel piscivore altered plankton assemblages within the lake and reduced nutrient transport to tributary streams $[49,86]$. Effects extended across the aquatic-terrestrial ecosystem boundary as grizzly bears and black bears in the area necessarily sought alternative foods $[41,87]$. Nest density and success of ospreys greatly declined, and bald eagles shifted their diet to compensate for the loss of cutthroat trout [41,52]. An urgent need for action to reverse these declining trends was recognized by resource managers, scientists, and a wide range of constituents of Yellowstone Lake fishery and wildlife resources.

\subsection{Scientific Review Panel}

Yellowstone National Park requested assistance from an independent scientific review panel in August 2008 to critically evaluate the effectiveness of the lake trout suppression program in Yellowstone Lake [88]. The panel was tasked with evaluating the effectiveness of the lake trout suppression program, reviewing emerging technological opportunities for suppressing lake trout, and providing alternatives for the future direction of the program in the context of the primary mission of the NPS, which is to preserve unimpaired the natural and cultural resources and values of the National Park System for the enjoyment, education, and inspiration of this and future generations. To that end, the panel sought to ensure the long-term persistence of native cutthroat trout and the natural function of the Yellowstone Lake ecosystem.

The panel concluded that suppression gillnetting during 1995 to 2008 had not curtailed lake trout population growth, and that the cutthroat trout population had declined severely; however, the cutthroat trout population was not completely lost and the ecosystem could be restored with immediate, aggressive action. Because overharvest had caused collapse of lake trout populations throughout their native range, the panel thought that intensified suppression gillnetting could drive the lake trout population of Yellowstone Lake into decline. Although specific gillnetting effort benchmarks that would result in lake trout decline could not be determined, the panel recommended a doubling of the 28,000 units of annual effort (unit of effort $=100$-m net nights) expended at that time. Because an immediate increase in gillnetting effort of that magnitude was beyond the capacity of NPS resources, the panel recommended incorporation of private sector (commercial, professional) gillnetters, an approach which was successful for lake trout suppression on Lake Pend Oreille in 
Northern Idaho [89]. The panel also recommended reinitiating lake trout telemetry studies to determine movement patterns, locate spawning habitats, and inform the suppression gillnetting. Additionally, development of novel suppression alternatives to gillnetting and experimentation to assess their effectiveness was also supported by the panel. Specific recommendations of the 2008 scientific review panel, 15 years after initial lake trout discovery, were to:

1. Intensify existing lake trout suppression efforts for a minimum of 6 years.

2. Maintain and enhance cutthroat trout monitoring.

3. Develop a statistically robust lake trout monitoring program.

4. Develop a lake trout suppression plan with benchmarks for control to increase program effectiveness and ensure the conservation of the Yellowstone Lake ecosystem through the coming decades.

\subsection{Planning and Environmental Compliance}

These major actions to suppress lake trout and restore the Yellowstone Lake ecosystem required increased funding, heightened support by partners and stakeholders, detailed long-term planning, and National Environmental Policy Act (NEPA) compliance. The recommendations of the scientific review panel provided a well-defined need for fund-raising to support the increased efforts. The park supported incorporation of private sector gillnetters during a limited, pilot phase during 2009 to 2010 to determine their feasibility for operations on Yellowstone Lake. Hickey Brothers Research, LLC, a company from Door County, Wisconsin, with extensive commercial fishing experience on Lake Michigan, was awarded the NPS contract to initiate the expanded gillnetting. Combined with the continued NPS operations, the enhanced gillnetting effort resulted in eradication of nearly a quarter million lake trout during 2009 to 2010. Yellowstone National Park concurrently completed an environmental compliance process evaluating potential effects on park resources by an increased suppression program. Input from the public was sought on alternative management actions that would ensure the long-term recovery of cutthroat trout and restoration of natural ecosystem function. A Native Fish Conservation Plan/Environmental Assessment (EA) was made available for review and comment on 16 December 2010 [90]. Development of the plan included scientific review of current conservation efforts, projected changes in native fish status given known threats, a review of relevant emerging science and technology, and public and stakeholder input received during a public scoping process. The plan that emerged identified the following goals:

- Reduction in the long-term extinction risk for native fishes;

- Restoration and maintenance of the important ecological role of native fishes; and

- Creation of sustainable native fish angling and viewing opportunities for the public.

The plan proposed to conserve native fish from threats of lake trout and other nonnative species, disease, and climate-induced environmental change. It provided guidance for managing fisheries and aquatic resources over the following two decades. The plan described in detail the development of an adaptive management strategy (Figure 5) for implementing large-scale removal of lake trout on Yellowstone Lake by NPS netting crews and incorporation of private sector, contract netters, and called for the development and implementation of robust monitoring and continued scientific review through collaboration with partners. Assumptions made in the selection of reasonable alternatives for the Yellowstone Lake ecosystem included:

- A direct relationship exists between lake trout gillnetting effort and the number of lake trout captured.

- Cutthroat trout will recover naturally without large-scale supplementation (stocking) once lake trout are functionally removed.

- A significant lag (in time) in the recovery of cutthroat trout will occur following lake trout suppression (cutthroat trout recovery may not be immediately perceptible).

- $\quad$ Large-scale supplementation (stocking) of cutthroat trout from existing hatchery broods would be detrimental because it would reduce the genetic integrity of the population. 
Table 1. Desired conditions, conservation actions, quantitative responses, and performance metrics for cutthroat trout (YCT) and lake trout (LKT) in the Yellowstone Lake ecosystem. Column labels A-D correspond to elements of the adaptive management strategy conceptual model (Figure 5).

\begin{tabular}{|c|c|c|c|}
\hline Desired Conditions & Conservation Actions & Quantitative Responses & Performance Metrics \\
\hline \multirow[t]{2}{*}{$\begin{array}{ll}\text { Primary } \\
\text { - } & \text { Restore YCT to } \\
& \text { pre-LKT abundances. } \\
\text { - } & \text { Free YCT of all stress by LKT. }\end{array}$} & $\begin{array}{l}\text { - } \quad \text { Gillnetting by NPS crews. } \\
\text { - } \quad \text { Incorpate sector, contract gillnetting. } \\
\text { emerging technologies. }\end{array}$ & \multirow{2}{*}{$\begin{array}{l}\text { - } \quad \text { YCT long-term gillnetting } \\
\text { - } \quad \text { assessment CPUE }>40 \text {. } \\
\text { visual surve of }>60 \text { spawning of } 11 \text { front } \\
\text { country tributaries. } \\
\text { - } \quad \text { Restored angler YCT catch to at least } \\
2.0 \text { per hour. } \\
\text { (1980s levels) }\end{array}$} & $\begin{array}{ll}\text { - } & \text { Reduce LKT population growth } \\
\text { rate }(\lambda) \text { to } 0.75 \text {. } \\
\text { - } \quad \text { LKT long-term gillnetting } \\
\text { assessment CPUE }<0.01 \text {. } \\
\text { - } \quad \text { Reduce angler LKT catch per hour } \\
\text { to }<0.05 \text {. }\end{array}$ \\
\hline & $\begin{array}{l}\text { - Reconnect spawning tributary } \\
\text { surface waters to the lake. }\end{array}$ & & $\begin{array}{l}\text { Each year } 75 \% \text { of tributaries } \\
\text { maintain a surface water } \\
\text { connection with the lake. }\end{array}$ \\
\hline \multirow{2}{*}{$\begin{array}{l}\text { Secondary } \\
\text { - } \quad \text { Restore YCT to abundance during } \\
\text { early stages of LKT invasion. } \\
\text { - Significantly reduce LKT stress } \\
\text { on YCT. }\end{array}$} & $\begin{array}{l}\text { - } \quad \text { Gillnetting by NPS crews. } \\
\text { - } \quad \text { Incorpate sector, contract gillnetting. } \\
\text { emerging technologies. }\end{array}$ & \multirow{2}{*}{$\begin{array}{l}\text { - YCT long-term gillnetting assessment } \\
\text { CPUE }>26 \text {. } \\
\text { - An average of }>40 \text { spawning YCT during } \\
\text { visual surveys of } 11 \text { front } \\
\text { country tributaries. } \\
\text { Restored angler YCT catch to at least } \\
1.5 \text { per hour. } \\
\text { (1990s levels) }\end{array}$} & $\begin{array}{l}\text { - } \quad \text { Reduce LKT population growth } \\
\text { rate }(\lambda) \text { to } 0.85 \text {. } \\
\text { - } \quad \text { LKT long-term gillnetting } \\
\text { assessment CPUE }<0.1 \text {. } \\
\text { - } \quad \text { Reduce angler LKT catch per hour } \\
\text { to }<0.05 \text {. }\end{array}$ \\
\hline & $\begin{array}{l}\text { - Reconnect spawning tributary } \\
\text { surface waters to the lake. }\end{array}$ & & $\begin{array}{l}\text { Each year } 75 \% \text { of tributaries } \\
\text { maintain a surface water } \\
\text { connection with the lake. }\end{array}$ \\
\hline \multirow{3}{*}{$\begin{array}{l}\text { Tertiary } \\
\text { - } \quad \text { Restore YCT to abundances during } \\
\text { later stages of LKT invasion. } \\
\text { - Moderately reduce LKT stress } \\
\text { on YCT. }\end{array}$} & $\begin{array}{l}\text { - } \quad \text { Gillnetting by NPS crews. } \\
\text { - } \quad \text { Private sector, contract gillnetting. } \\
\text { - } \quad \text { Incorporate new and emerging } \\
\quad \text { technologies. }\end{array}$ & \multirow{3}{*}{$\begin{array}{l}\text { - YCT long-term gillnetting assessment } \\
\text { CPUE }>12 \text {. } \\
\text { An average of }>20 \text { spawning YCT during } \\
\text { visual surveys of } 11 \text { front } \\
\text { country tributaries. } \\
\text { - Restored angler YCT catch to at least } \\
1.0 \text { per hour. } \\
\text { (2000s levels) }\end{array}$} & $\begin{array}{l}\text { - } \quad \text { Reduce LKT population growth } \\
\text { rate }(\lambda) \text { to } 0.95 \text {. } \\
\text { - } \quad \text { LKT in long-term gillnetting } \\
\text { assessment is }<0.5 \text {. }\end{array}$ \\
\hline & $\begin{array}{l}\text { - Reconnect spawning tributary } \\
\text { surface waters to the lake. }\end{array}$ & & $\begin{array}{l}\text { Each year } 75 \% \text { of tributaries } \\
\text { maintain a surface water } \\
\text { connection with the lake. }\end{array}$ \\
\hline & $\begin{array}{l}\text { - Reintroduce YCT to tributaries } \\
\text { lacking use by spawners. }\end{array}$ & & $\begin{array}{l}\text { - Establish self-sustaining YCT } \\
\text { spawning populations } \\
\text { in tributaries. }\end{array}$ \\
\hline
\end{tabular}




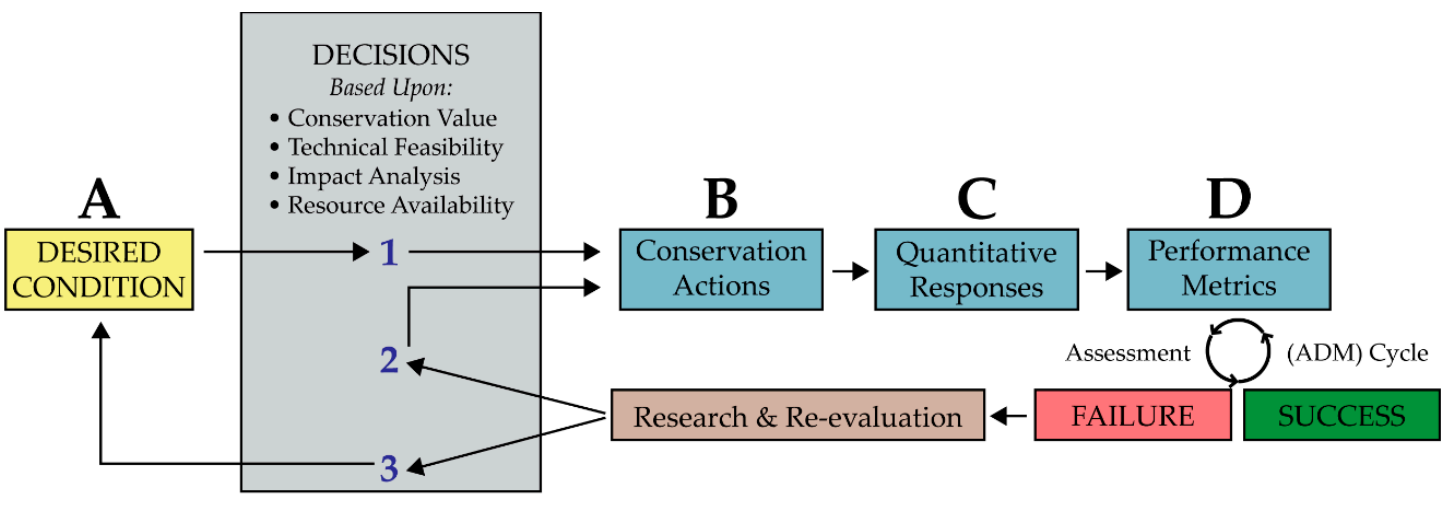

Decision Nodes: 1 . If resonable and prudent, then proceed to original conservation action(s).

2. If solution is known and prudent, then proceed to modified action(s).

3. If solution is unknown or not prudent, then consider for an alternate desired condition.

Figure 5. Adaptive management (ADM) strategy conceptual model for Yellowstone Lake ecosystem restoration. Desired condition (A), conservation actions $(\mathbf{B})$, quantitative responses $(\mathbf{C})$, and performance metrics (D) are defined in the text and listed in Table 1 [90].

Because $>100,000$ lake trout were being killed annually by 2010, the plan included an alternative analysis of the marketing and sale (or the donation) of gillnetted lake trout for human consumption. The thought was that proceeds from the sale of lake trout could be used to supplement the increased funding needed for the program. However, a large portion of the catch was not suitable for human consumption because the soak times of suppression gillnets were often 7 nights. In addition, handling time and care, including holding fish on ice and transport, would greatly reduce time available for suppression gillnetting. Gillnetting effort would decrease by about an estimated $50 \%$ if lake trout were processed for human consumption, requiring a doubling of the number of boats and crews to maintain the same gillnetting suppression effort. Markets and food banks were far from Yellowstone Lake, resulting in high shipment costs. Moreover, the enabling legislation for Yellowstone National Park does not allow for the sale of its natural resources. Sale or donation of lake trout was rejected because of these significant issues. The lake trout carcasses were to instead be deposited in deep ( $>65 \mathrm{~m})$ regions of the lake to retain their nutrients within the lake ecosystem.

\subsection{Conceptual Ecosystem Model and Hypothesized Linkages}

A conceptual model (Table A3) was developed to assist in identifying issues confronting the Yellowstone Lake ecosystem and to clarify which aspects of the ecosystem would likely respond as a result of management actions. The conceptual model illustrated the complex relations among agents of change, stressors on native fish, and ecosystem responses. Agents of change were sources of stressors on native fish when they operated outside the range of natural variability; they included natural processes and events as well as human activities. Ecosystem responses were defined as measurable and detectable changes or trends in the quality or integrity of ecosystem structure, function, or processes.

Agents of change appropriate to the Yellowstone Lake ecosystem were organized into five broad categories (Table A3):

- regional physical/chemical forces;

- biological introductions;

- angling;

- park infrastructure and operations; and

- local physical/chemical forces.

The degree to which each agent of change contributed to a problem was considered and a list of potential stressors on native fish was compiled. Each stressor was matched to general management 
issues within the 2006 NPS Management Policies [91]. The preliminary list of ecosystem responses was also grouped into five broad categories (Table A3):

- biogeochemical cycling;

- productivity/biomass change;

- fish functional role;

- fish life history strategy; and

- avian/terrestrial fish consumers.

For example, the lake trout invasion was an agent of change within the Yellowstone Lake ecosystem that resulted in stressors on native fish in the form of fewer cutthroat trout recruited to the spawning population, direct mortality, predation losses, and loss due to competition/displacement (Table A3). These stressors can also result in ecosystem responses such as changes in nutrient transport, primary and secondary production, fish functional roles and life history strategies, and impacts on avian and terrestrial fish consumers. The conceptual model was not intended to represent a comprehensive account of the entire ecosystem but rather was a framework implicating known or hypothesized agents of change that stress native fish and result in negative ecosystem responses. The goal of the model was to illustrate relationships between and among agents of change and key ecosystem processes and variables. It served to demonstrate the complexity of interactions within the Yellowstone Lake ecosystem, many of which are unknown. Multiple agents of change can lead to multiple stressors, resulting in multiple ecosystem responses.

The underlying hypotheses for the preferred alternative of the Native Fish Conservation Plan were that a gillnetting-driven reduction in lake trout would result in cutthroat trout recovery, and this recovery would, in turn, result in positive responses by piscivorous wildlife (Table A3). In addition, the cascading changes within the lake that followed the cutthroat trout decline (e.g., shifts in zooplankton, phytoplankton, and nutrient transport) would revert to pre-lake trout conditions.

\subsection{Desired Conditions}

Primary, secondary, and tertiary desired conditions for the Yellowstone Lake ecosystem were described in the Native Fish Conservation Plan (Table 1) [90]. Complete eradication of lake trout, the most significant agent of change, was the primary desired condition for Yellowstone Lake. However, the secondary condition was initially set as the management target because available lake trout suppression methods were incapable of achieving the primary desired condition. The tertiary condition would become the management target if implementation of conservation actions did not achieve the secondary desired condition. Failure to achieve at least the tertiary condition would be considered a failure to meet the objectives of the plan. Although cutthroat trout are expected to naturally recover following lake trout decline, conservation actions of all desired conditions included ensuring spawning tributary connectivity to Yellowstone Lake during drought years $[51,90,92]$ and reintroduction (stocking) of cutthroat trout to tributaries lacking use by spawners if deemed necessary to maintain the tertiary desired condition.

\subsubsection{Primary Desired Condition}

The primary desired condition was characterized by cutthroat trout restored to pre-lake trout abundances, and free from all stress by lake trout. This condition would be achieved by a $100 \%$ eradication of lake trout or a suppression of lake trout to the point where the species had no measurable impact on the ecology of Yellowstone Lake. Quantitative responses to characterize this condition would include full recovery of cutthroat trout abundance to the averages observed during the five years prior to lake trout discovery (1987-1991; 40 per 100-m net night during long-term gillnetting assessments (relative abundance monitoring, see below); 60 observed during visual spawning surveys; angler catch rate of 2.0 per hour; Table 1). Performance metrics were a lake trout population growth rate $(\lambda) \leq 0.75$; catch-per-unit-effort $(\mathrm{CPUE})=0.01$ per 100 -m net night during long-term gillnetting 
assessments; and angler catch rate $<0.05$ per hour. Lake trout abundance would be extremely low and difficult to detect in this condition.

\subsubsection{Secondary Desired Condition}

The secondary desired condition would be characterized by restoration of cutthroat trout to abundances present during the early stages of lake trout invasion, indicating significantly reduced lake trout stress on cutthroat trout. This condition would be achieved by significantly reducing lake trout abundance in Yellowstone Lake. Quantitative responses to characterize this condition would include recovery of cutthroat trout abundance to the averages observed during the five years following lake trout discovery (1995-1999; 26 per 100-m net night during long-term gillnetting assessments; 40 observed during visual spawning surveys; angler catch rate of 1.5 per hour; Table 1 ). Performance metrics were a lake trout population growth rate $(\lambda) \leq 0.85$; CPUE $=0.1$ per $100-\mathrm{m}$ net night during annual long-term gillnetting assessments; and angler catch rate $<0.1$ per hour.

\subsubsection{Tertiary Desired Condition}

The tertiary desired condition would be characterized by cutthroat trout restored to abundances during the later stages of lake trout invasion, indicating moderately reduced lake trout stress on cutthroat trout. This condition would be achieved by slightly reducing lake trout abundance in Yellowstone Lake. Quantitative responses to characterize this condition would include maintaining cutthroat trout abundance at the average observed prior to lake-wide expansion by lake trout (2001-2005; 12 per 100-m net night during long-term gillnetting assessments; 20 observed during visual spawning surveys; angler catch rate of 1.0 per hour; Table 1). Performance metrics were a lake trout population growth rate $(\lambda) \leq 0.95$; CPUE $=0.5$ per 100 -m net night during annual long-term gillnetting assessments; and angler catch rate $<0.5$ per hour.

\section{Stakeholder Involvement and Fundraising to Support Conservation Actions}

Following completion of the Native Fish Conservation Plan/EA [90], a Finding of No Significant Impact (FONSI) was signed by the NPS Intermountain Region Director in June 2011. That year, Yellowstone National Park entered into a 5-year contract with Hickey Brothers Research, LLC, to increase lake trout gillnetting suppression effort lakewide. In addition, research to improve suppression efficiency began in earnest as adult lake trout were surgically implanted with acoustic tags to determine broad scale movement patterns and locate key spawning sites. A plan with clearly articulated objectives and benchmarks for Yellowstone Lake ecosystem restoration and feedback from annual scientific panel reviews provided strength for acquiring funding to support the program. Missing however, was a process to better incorporate anglers, conservation groups, and the general public in on-the-ground actions to conserve native fish as described in the plan.

\subsection{Yellowstone Fly Fishing Volunteer Program}

The Yellowstone Fly Fishing Volunteer Program was initiated in 2002 to acquire information about fish populations throughout the park without requiring Yellowstone biologists to travel to sample the populations themselves using electrofishing or other sophisticated gear [93]. The volunteers fly-fished to gather and archive information and biological samples that park biologists would otherwise not be able to collect. In addition to providing valuable data, samples, and assistance to the fisheries program, volunteer fly fishers have played an important role with the public by interacting positively with park biologists and the public and demonstrating their passion for native fish and the importance of protecting these species. Volunteer fly fishers have promoted an understanding of the Yellowstone Lake ecosystem restoration program and generated greater awareness of the current issues facing Yellowstone's native fish. These passionate and informed supporters have been an important contribution to the success of our program. 


\subsection{Yellowstone Lake Workgroup}

A consortium of conservation groups met with NPS officials in 2011 with the intent of becoming partners in addressing the threats to the Yellowstone Lake fishery and ecosystem. From that meeting and subsequent discussions, a Memorandum of Understanding (MOU) was developed that formalized a cooperative relationship among participants to ensure the ecosystem was protected, maintained, and managed to achieve established goals. Signatories to the MOU were Trout Unlimited National, Wyoming Council, Montana Council, and Idaho Council; National Parks Conservation Association; Greater Yellowstone Coalition; Yellowstone Park Foundation (subsequently named Yellowstone Forever); and Yellowstone National Park. These stakeholders began meeting semi-annually and created a formal Yellowstone Lake Workgroup that acted as a sounding board to review lake trout suppression activities, population monitoring activities and trends, telemetry research results, new suppression technologies, and other fisheries-related science. They also initiated positive public outreach and education and authored publications directed at the general public and potential donors, including a publication with answers to frequently asked questions about the science supporting management of Yellowstone Lake [94]. The group has responded to public concerns about fish conservation actions when applicable. The Yellowstone Lake Workgroup has been actively involved in fundraising and has raised over US $\$ 1$ million to directly support cutthroat trout restoration in Yellowstone Lake. The majority of the funds have been spent on (1) telemetry studies to determine lake trout seasonal movement patterns and location of spawning areas, (2) studies assessing the reproductive potential, cycles, and timing of lake trout spawning, and (3) studies to identify and optimize alternative suppression technologies aimed at lake trout embryos. In addition, members of the Yellowstone Lake Workgroup have provided volunteer labor to support the work on Yellowstone Lake.

\subsection{Yellowstone Forever Fund-Raising Partnership}

As the need for lake trout suppression effort increased, so did the need for increased funding to support it. Funding for the Yellowstone Lake ecosystem restoration was $\leq$ US\$500,000 until 2009, when it was increased to support expanded suppression effort by contracted gillnetters. Yellowstone Forever, which was the official fund-raising partner of Yellowstone National Park, approved a grant in 2012 to initiate strong, annual support of the program. This support, funded by private donations, increased total program funding (donated and NPS) from US $\$ 1,000,000$ in 2011 to more than US $\$ 2,000,000$ by 2013 (Figure 6A). These funds allowed a rapid increase in suppression gillnetting effort by the contracted crews to meet (and surpass) annual gillnetting benchmarks, while concurrently enhancing long-term monitoring, population modeling, and applied research to improve program efficiency. 

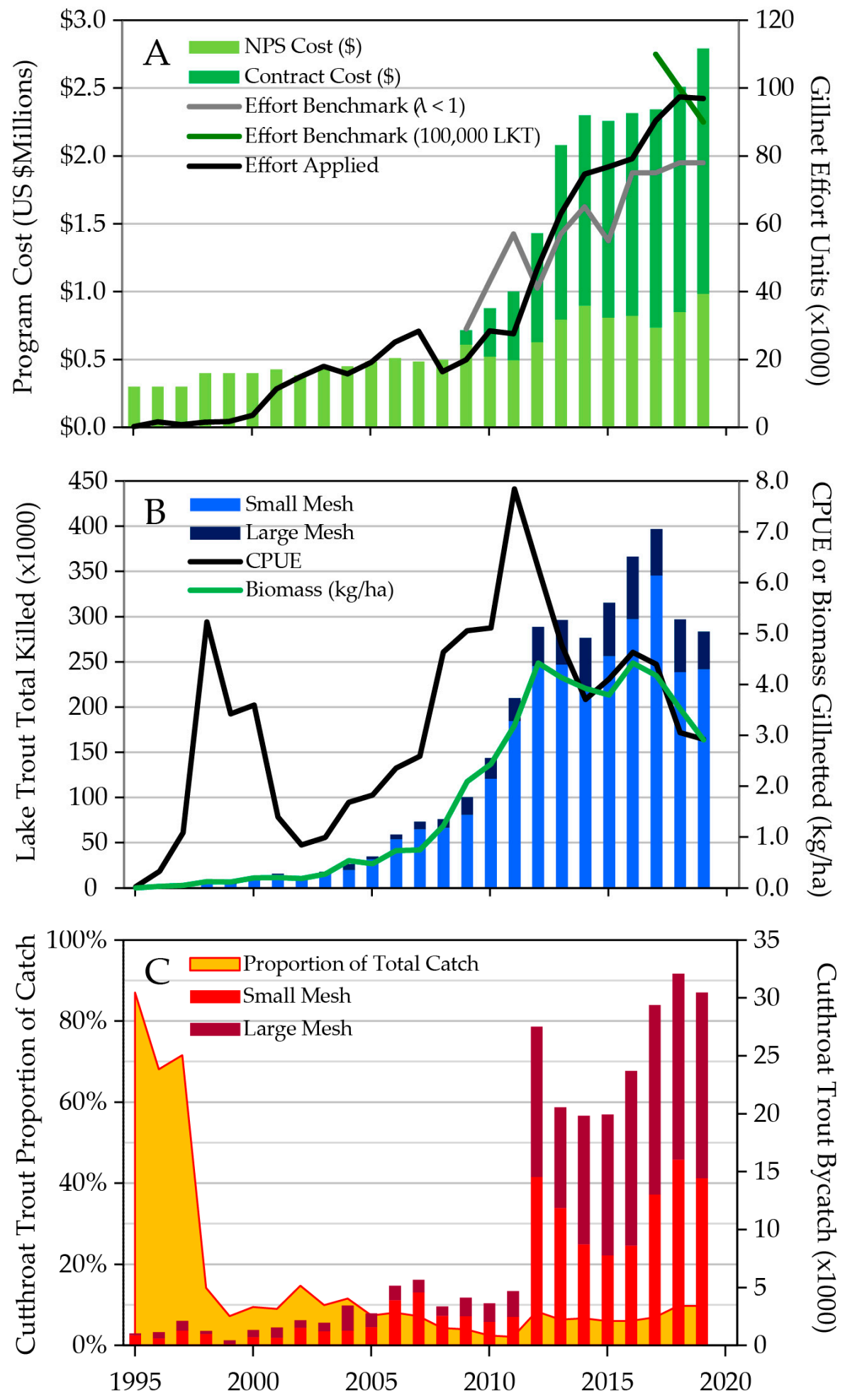

Figure 6. Costs, effort, and catch of the Yellowstone Lake ecosystem restoration program, 1995-2019, including (A) the total program cost (US \$Millions) of National Park Service (NPS) and contracted operations, gillnetting effort unit (100-m net nights) benchmarks estimated by statistical-catch-at-age modeling to achieve $\lambda<1$ (2009-2019) or to reduce lake trout (LKT) total abundance to 100,000 fish (2017-2019), and the actual total annual gillnetting effort applied, (B) total numbers of lake trout killed by small and large mesh gillnets, catch-per-unit-effort (CPUE) by all mesh sizes combined, and total biomass of lake trout gillnetted, and (C) cutthroat trout proportion (\%) of total gillnet catch and number of bycatch in small and large mesh gillnets. 


\section{Historical Development of the Gillnetting Program}

Gillnets have remained the primary lake trout suppression gear on Yellowstone Lake throughout the first 25 years of the program because they were the preferred gear in commercial fisheries and could overharvest lake trout populations in their native range [83,95]. At first (1995-1999), lake trout distribution or abundance in Yellowstone Lake was poorly understood, crews were inexperienced in population suppression gillnetting, and boats lacked specializations for lifting and processing long gillnets. Summer (June-September) gillnet sets were short $(<200 \mathrm{~m}$ length $)$ and mostly lifted by hand from relatively small $(6-8 \mathrm{~m})$ research and monitoring vessels. Despite these constraints, NPS crews annually processed an average of $1164100-\mathrm{m}$ net nights and killed an average of 2965 lake trout (14,823 total lake trout killed during 1995-1999, mean CPUE = 2.1 per 100-m net night, mean biomass caught $=0.07 \mathrm{~kg} / \mathrm{ha}$; Figure $6 \mathrm{~B}$ ) with nearly all of the effort focused in the West Thumb region, where the original discovery of lake trout occurred and catch rates were highest (Figure 7).

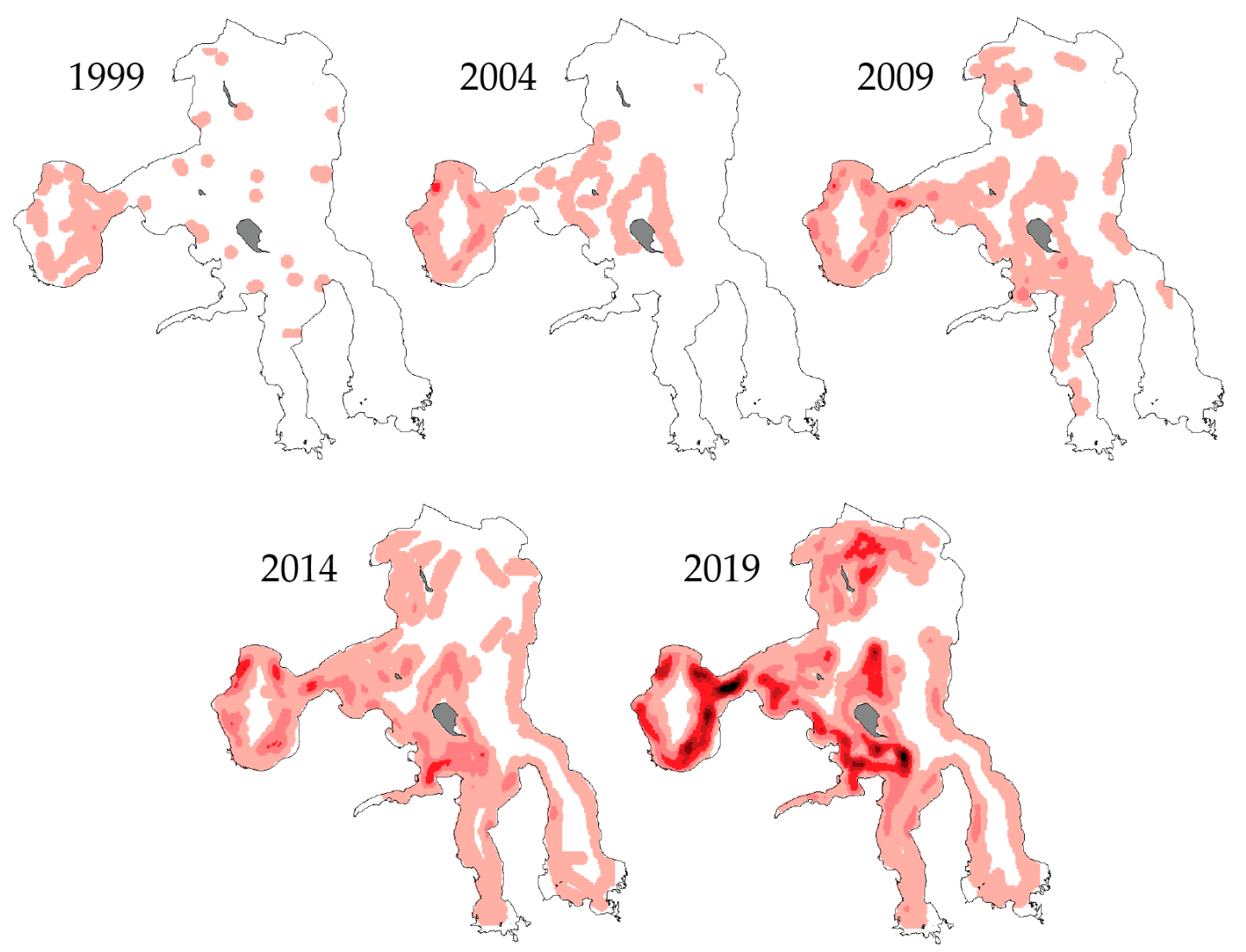

Figure 7. Spatial expansion and increase in intensity of suppression gillnetting effort on Yellowstone Lake during years of rapid lake trout population growth $(1999,2004$, and 2009) and years where distribution of gillnets and overall effort was great enough to curtail population growth (i.e., $\lambda<1$; 2014 and 2019). Darker shades of red indicate lake areas with greater intensity of gillnetting effort.

National Park Service crews increased gillnetting effort and total lake trout killed after acquisition of a large $(10 \mathrm{~m})$ enclosed gillnetting boat in 2001 . Both the new boat and an existing boat $(8 \mathrm{~m})$ were outfitted with hydraulic net lifters, thereby greatly increasing their ability to retrieve long gangs of nets (550 m). Crews used sonar and detailed lake bathymetry [96] to locate concentrations of lake trout and extended gillnetting throughout the possible field season from late-May through mid-October in 2000-2004 to increase gillnetting effort more than 10-fold throughout the Breeze Channel and into the Main Basin of Yellowstone Lake (Figure 7). An average of 12,675 100-m net nights were processed during this period resulting in the kill of 17,072 lake trout annually $(85,861$ total lake trout killed 
during 2000-2004, mean CPUE $=1.7$ lake trout per 100-m net night, mean biomass caught $=0.28 \mathrm{~kg} / \mathrm{ha}$; Figure 6B).

Gillnet effort and lake trout killed increased again during 2005-2009 as experienced NPS crews focused solely on suppression. Netting effort expanded across Yellowstone Lake (Figure 7) to follow the increasing lake trout population that, despite the 10+ years of control efforts, was experiencing exponential growth. A pilot study of contracted gillnet services initiated in 2009 brought a third specialized gillnetting vessel to the lake and increased gillnetting effort by 3 weeks in 2009. An average of 21,769 100-m net nights were processed and 68,761 lake trout were killed annually (343,807 total lake trout killed during 2005-2009, mean CPUE = 3.3 lake trout per 100-m net night; mean biomass caught $=1.05 \mathrm{~kg} / \mathrm{ha}$; Figure $6 \mathrm{~B}$ ).

The gillnetting effort was increased during 2010 to 2014 to a level that curtailed further lake trout population growth [81] as a result of (1) completion of the Native Fish Conservation Plan/EA, (2) estimation of gillnetting benchmarks by population modeling (see below), (3) growing support of stakeholders, (4) significant private donor funding support, and (5) guidance by the scientific review panel. Five large, specialized gillnetting vessels expanded effort and spatial distribution of gillnets across Yellowstone Lake (Figure 7). Contiguous gillnet lengths were increased to $>3 \mathrm{~km}$ by the contract crews and were set in a serpentine pattern along bottom contours to maximize catch of lake trout, which swam parallel to net panels. The increased effort focused on large adult lake trout, especially during the autumn spawning period, while not reducing effort targeting smaller lake trout [97] (Figure 6B). The increased focus on adult lake trout along with telemetry of acoustic-tagged fish (see below) resulted in the discovery of several additional lake trout spawning sites that were subsequently targeted $[59,98]$. During this period of rapid effort expansion, an average of 48,073 100-m net nights were processed and 249,466 lake trout were killed annually $(1,247,332$ total lake trout killed during 2010-2014, mean CPUE $=5.6$ per 100-m net night; mean biomass caught $=3.62 \mathrm{~kg} / \mathrm{ha}$; Figure 6B).

Large deepwater trap nets were set for extended periods (months) in fixed locations in 2010-2013 to complement gill netting and maximize capture of large adult lake trout (and minimize cutthroat trout bycatch) [42]. The trap nets also captured live lake trout for critical telemetry studies (see below). Although the trap nets caught nearly 33,000 additional adult lake trout during a total of 2810 net nights over four years, the fish were of the same size classes caught by large-mesh gillnets. Moreover, the trap nets, which were 9-15 $\mathrm{m}$ high, had complex leads > $300 \mathrm{~m}$ long, were held in place by heavy $(50 \mathrm{~kg})$ anchors, and required highly trained contracted crews to set and maintain. Use of the trap nets was discontinued after 4 years because the time and cost of their use were high relative to that required to achieve similar catches with gill nets.

The suppression program was expanded during 2015 to 2019 with the purchase of an additional NPS gillnetting vessel resulting in a total of six large specialized boats (Figure A4) and crews (NPS and contract) with substantial fishing experience (Video S2). Although all size classes of lake trout were targeted, effort continued to be focused on removal of large, adult lake trout. Net inventories were increased greatly to accommodate the increase in effort and included a broad range of mesh sizes to target the changing population and maximize catches throughout the suppression season. Twine (monofilament) diameters were reduced, which increased catch efficiencies. Gillnets were distributed across most of the lake that was $<60 \mathrm{~m}$ deep, the depths that had proven to be most productive (Figure 7). Proportionally, effort continued to be highly focused on the West Thumb, Breeze Channel, and Main Basin regions near Frank Island where catches remained the highest (Figure 1). Experienced, professional gillnetting crews processed an average of 88,124 100-m net nights resulting in an annual average kill of 331,783 lake trout and a reduced CPUE (1,658,917 total lake trout killed during 2015 to 2019 , mean CPUE $=3.8$ lake trout per 100-m net night; mean biomass caught $=3.77 \mathrm{~kg} / \mathrm{ha}$; Figure 6B).

Bycatch of cutthroat trout has occurred throughout the gillnetting program. Both lake trout and cutthroat trout occupy shallow-water habitats during spring and autumn despite spatial segregation 
during summer stratification (late-July through mid-September) when lake trout seek cold, deep lake areas. Targeted gillnetting of lake trout while avoiding cutthroat trout bycatch has therefore been challenging during spring and autumn. Immediately following the discovery of lake trout during $1995-1997,68 \%-87 \%$ of annual catches were cutthroat trout (Figure 6C). As lake trout abundances increased and crews developed better methods to target them, the bycatch of cutthroat trout declined to $<15 \%$. Annual bycatch increased to about 20,000-30,000 cutthroat trout beginning in 2012, concurrent with rapid expansion of gillnetting effort and cutthroat trout recovery. Bycatch makes up only about $6 \%-10 \%$ of the total catch but is an unfortunate consequence of the use of gill nets as the primary lake trout suppression tool. However, the number of cutthroat trout saved by the killing of 100,000s of lake trout annually far exceeds bycatch losses given that each lake trout consumes an estimated 41 cutthroat trout annually [79].

\section{Lake Trout Population Modeling and Gillnetting Effort Benchmarks}

The most robust approach for evaluating the success of the lake trout suppression program was a combination of long-term monitoring and population modeling [99-101]. We estimated lake trout abundances and mortality through time by integrating gillnetting effort, harvest data, and standardized monitoring data (long-term gillnetting assessments, described below) in a statistical catch-at-age (SCAA) assessment model $[80,81,102]$. The results of the SCAA model were used to forecast the amount of gillneting effort required to achieve a given level of mortality [103,104]. Our goal, established in 2010, was to reduce the abundance of lake trout to their mid-1990s levels (about 100,000 fish), when they probably had little effect on the native cutthroat trout population [90]. However, a major uncertainty in reaching that goal was the amount of gillnetting effort needed. Population modeling and analyses of lake trout suppression data collected over several years were used to address this question and to assess suppression program success. The three important metrics assessed were (1) total annual mortality, (2) population abundance, and (3) population growth rate $(\lambda)$ of lake trout.

Annual gillnetting effort benchmarks were estimated iteratively using the SCAA model beginning in 2009, when 29,000 100-m net nights were predicted to be needed to reduce $\lambda<1$ within 5 years (Figure 6A). This initial benchmark was estimated using age- 0 and age- 1 survival rates from the native range of lake trout [80]. Subsequent analyses of local data indicated that pre-recruit survival rates in Yellowstone Lake were much higher than in the native range and the model was adjusted accordingly. The benchmark increased to 57,000 units in 2011 and stabilized at 75,000 units from 2016 to 2019 . Because annual lake trout harvests remained high, we estimated the effort required to reduce lake trout abundance to the goal of 100,000 fish identified in the Native Fish Conservation Plan. This target ranged from 90,000 to 110,000 100-m net nights between 2017 and 2019, respectively, which appeared to be converging with estimates of effort required to maintain $\lambda<1$ (Figure $6 \mathrm{~A}$ ). Fortunately, the combined NPS and contracted suppression gillnetting crews were able to achieve $>90,000$ effort units in those years.

\section{Lake Trout Population Response to Suppression Gillnettting}

Annual monitoring metrics indicated that suppression gillnetting successfully reduced lake trout abundances (ages $3+$ ) and biomass. The catch rate of lake trout in annual long-term gillnetting assessments declined from 2011 to 2019 ( $p=0.032$ ), with a high of 4.9 per 100-m net night in 2014 and a low of 2.0 in 2018 (Table A4, Figure 8), but remained above established desired conditions (Table 1). Large adult lake trout (> $400 \mathrm{~mm}$ ) consistently made up $13 \%$ to $29 \%$ of the catch. Proportions of the catch $\leq 280 \mathrm{~mm}$ (primarily age-2 individuals) were $<50 \%$ in all years except 2019 when small lake trout made up $63 \%$ of the catch (Figure A5). Small, juvenile lake trout consistently represented a large proportion of the annual catch, suggesting that recruitment remained strong. 


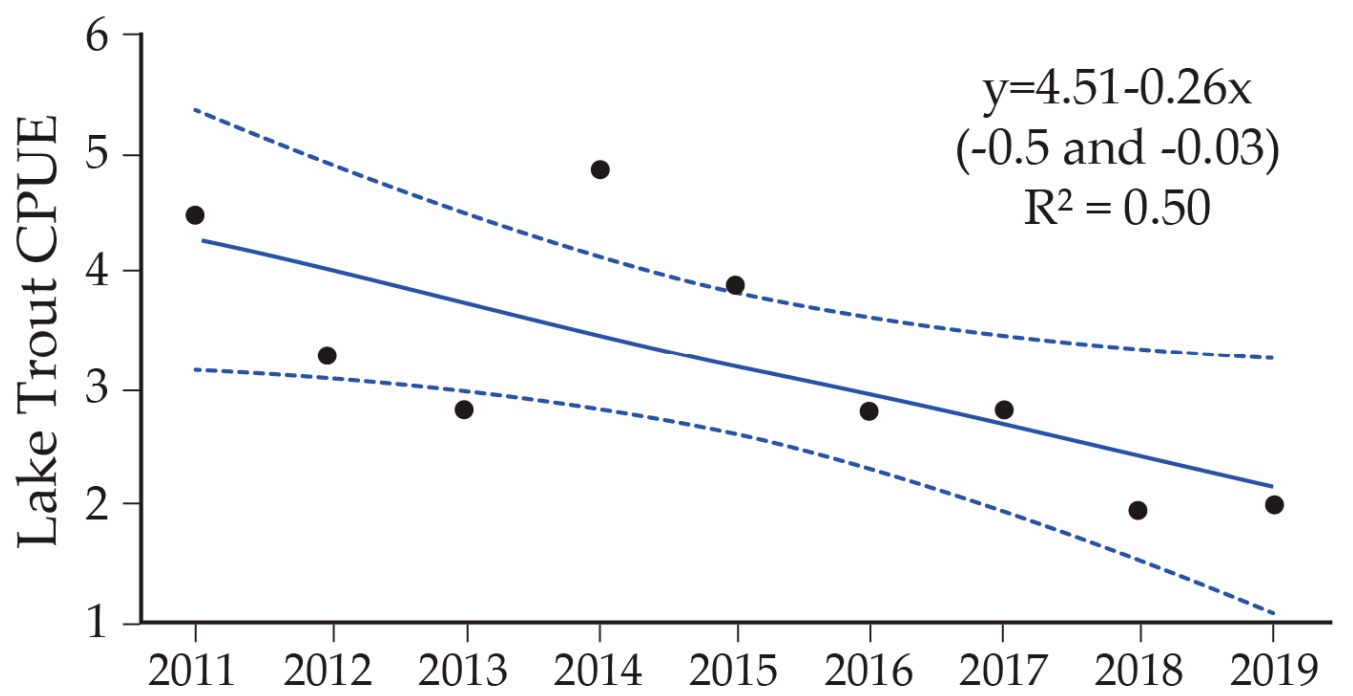

Figure 8. Catch-per-unit-effort (CPUE) of lake trout during annual long-term gillnetting assessments on Yellowstone Lake, 2011-2019. The blue line represents a simple linear regression model with $95 \%$ confidence intervals (dashed lines). Numbers within parentheses are the upper and lower $95 \%$ confidence limits of the slope parameter estimate, indicating a temporal decline in the CPUE response variable because the interval does not include zero.

Total lake trout abundance estimates (age 2 and older, at the beginning of the year, derived from the SCAA model, Table A5) declined ( $p=0.038$ ) from 925,208 in 2012 to 673,983 in 2019 (Figure 9A) after suppression gillnetting effort increased sufficiently to curtail lake trout population growth (i.e., $\lambda<1$ ). However, high among-year variation in estimated total abundance $\left(R^{2}=0.54\right)$ was apparently driven by highly variable recruitment of age- 2 fish to the population. Abundances of age-2 lake trout during 2012 to 2019 ranged from a low of 318,640 in 2013 to a high of 480,961 in 2015 and no significant relationship existed between abundance and year $(p=0.834$, Figure 10A). Abundances of age 3-5 $(p=0.011)$ and age $6+(p<0.001)$ lake trout declined from 416,814 and 57,722 in 2012 to 197,681 and 12,345 in 2019, respectively (Figure 10B,C). These declines resulted in a $54 \%$ decrease in total lake trout biomass ( $p<0.001$ ) from 432,017 kg in 2012 to 196,675 kg in 2019 (Figure 9B).

The lake trout population growth rate ( $\lambda$ ) from 2017 to 2018 was 0.75 (95\% CI: 0.65-0.85), which met our primary desired condition for this performance metric (Table 1) [81]. However, it grew to 1.18 (95\% CI: 0.95-1.40) from 2018 to 2019 because of high age-2 recruitment. Even though total abundances of older lake trout declined between 2012 and 2017, abundance of age-2 lake trout increased by 69\% between 2018 and 2019 (Figure 10A) because of the high year-class strength of the 2017 cohort, which was detected in 2019 after it recruited to the gear. This increase in recruitment, despite reductions in adult abundances, indicated a compensatory response by the lake trout population. Lake trout length at maturity did not change between 1995 and 2019; female lake trout matured at $515 \mathrm{~mm}$ (95\% CL: 503-525) and male lake trout matured at $431 \mathrm{~mm}$ (95\% CL: 423-444) (Figure A6). However, relative condition $\left(K_{n}\right)$ of large lake trout $(400+\mathrm{mm})$, increased during this period, from 102.8 during 1995-1999 to 111.8 during 2005-2019 (Table A6, Figure A7). Nevertheless, estimated total egg production declined from 51.1 million in 2010 to only 15.8 million in 2017 (Figure 11). Accordingly, age-2 recruitment was maintained despite reductions in abundances of adults and egg production. 

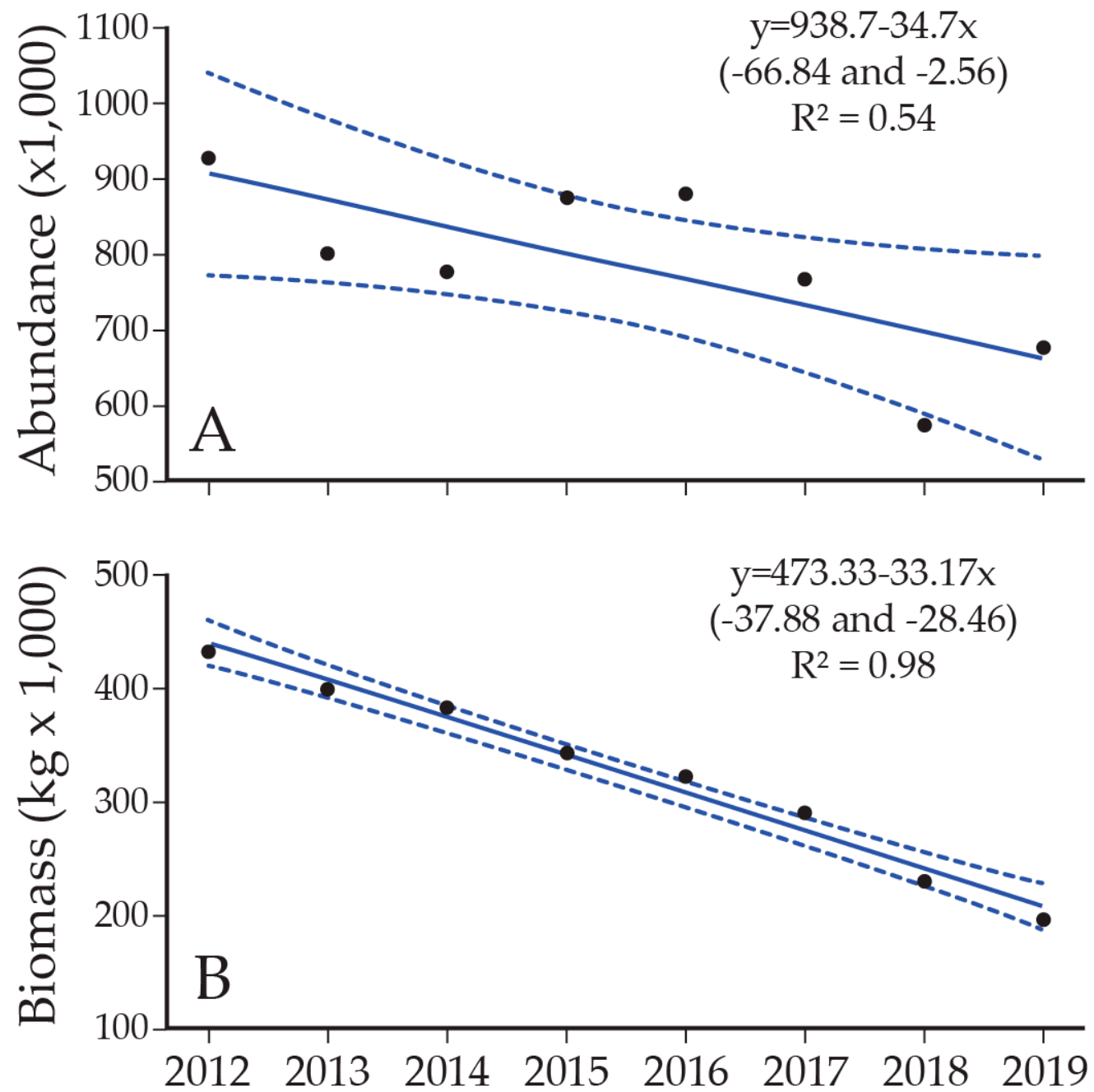

Figure 9. Total (A) abundance and (B) biomass of age-2 and older lake trout at the start of the year from 2012 through 2019 estimated using a statistical catch-at-age (SCAA) model [81]. Blue lines represent simple linear regression models with 95\% confidence intervals (dashed lines). Numbers within parentheses are the upper and lower $95 \%$ confidence limits of the slope parameter estimate, indicating temporal declines in these response variables because intervals do not include zero.

Mandatory angler-harvest of lake trout, which was implemented immediately upon lake trout discovery, is substantial at about $5 \%$ of the total killed by all methods (angling and suppression gillnetting) combined in recent years. Moreover, angler harvest is additive to total mortality and comes at no cost to the program. Annual angler harvest increased from an estimated 500 lake trout in 1995 to 2900 in 1999 and averaged about 17,000 after 2002. Angler catch rate declined from 0.5 fish per hour in 2012 to 0.2 per hour in 2019 but remained above desired conditions for this performance metric $(<0.05$ lake trout per hour; Table 1$)$. Historically, more than $50 \%$ of lake trout caught by anglers were large ( $>450 \mathrm{~mm}$ ), but only $32 \%-34 \%$ were $>450 \mathrm{~mm}$ during 2017 to 2019 , reflecting the reduced abundance caused by suppression gillnetting. Anglers have consistently caught fewer lake trout than cutthroat trout in Yellowstone Lake. 

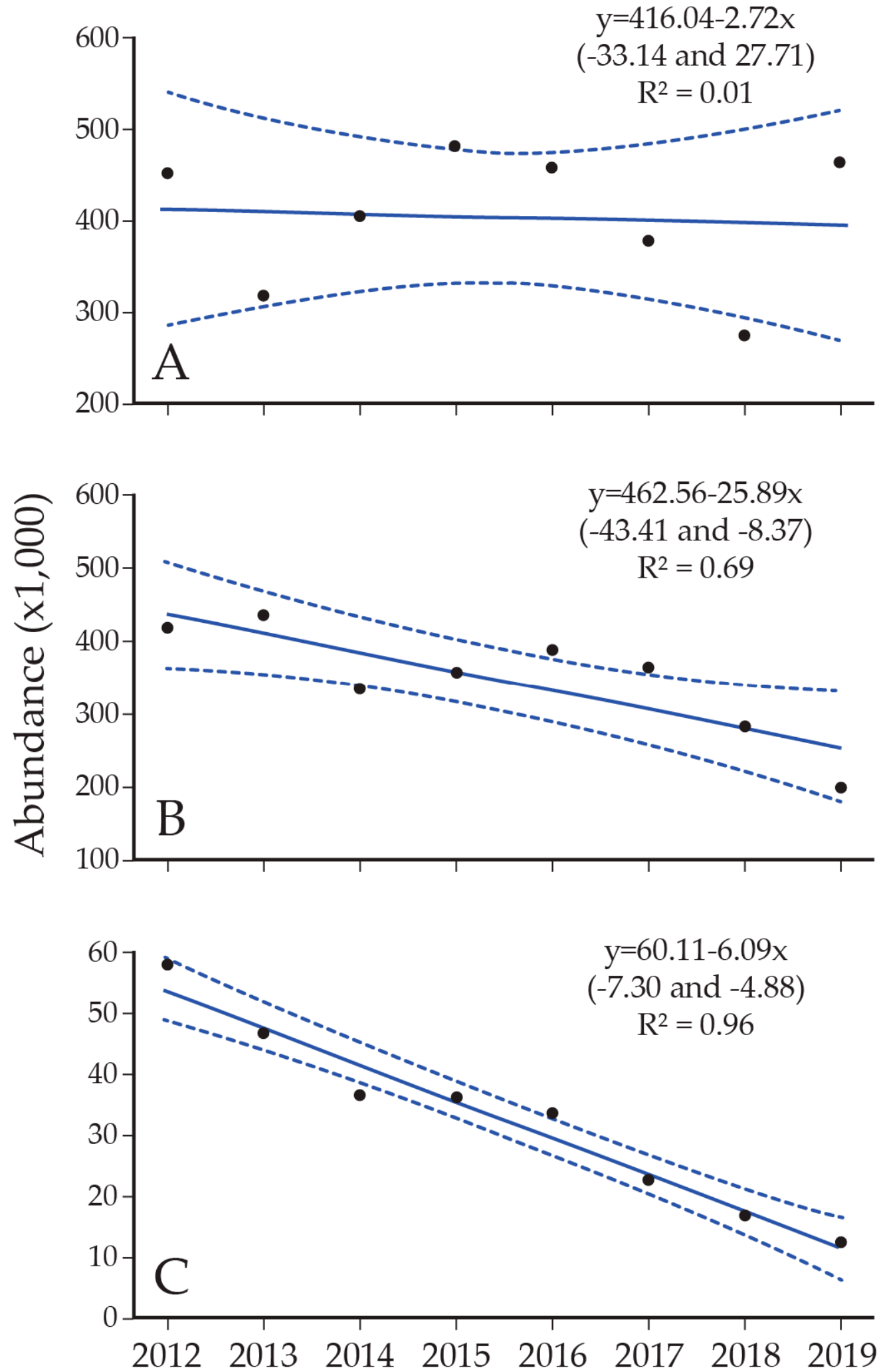

Figure 10. Abundances of (A) age-2, (B) age-3 to age-5, and (C) age-6+ lake trout at the start of the year from 2012 through 2019 estimated using a statistical catch-at-age (SCAA) model [81]. Blue lines represent simple linear regression models with $95 \%$ confidence intervals (dashed lines). Numbers within parentheses are the upper and lower $95 \%$ confidence limits of the slope parameter estimate. There was no temporal change in age- 2 abundance because the interval includes zero. Age- 3 to age- 5 abundance and age- $6+$ abundance declined significantly. 


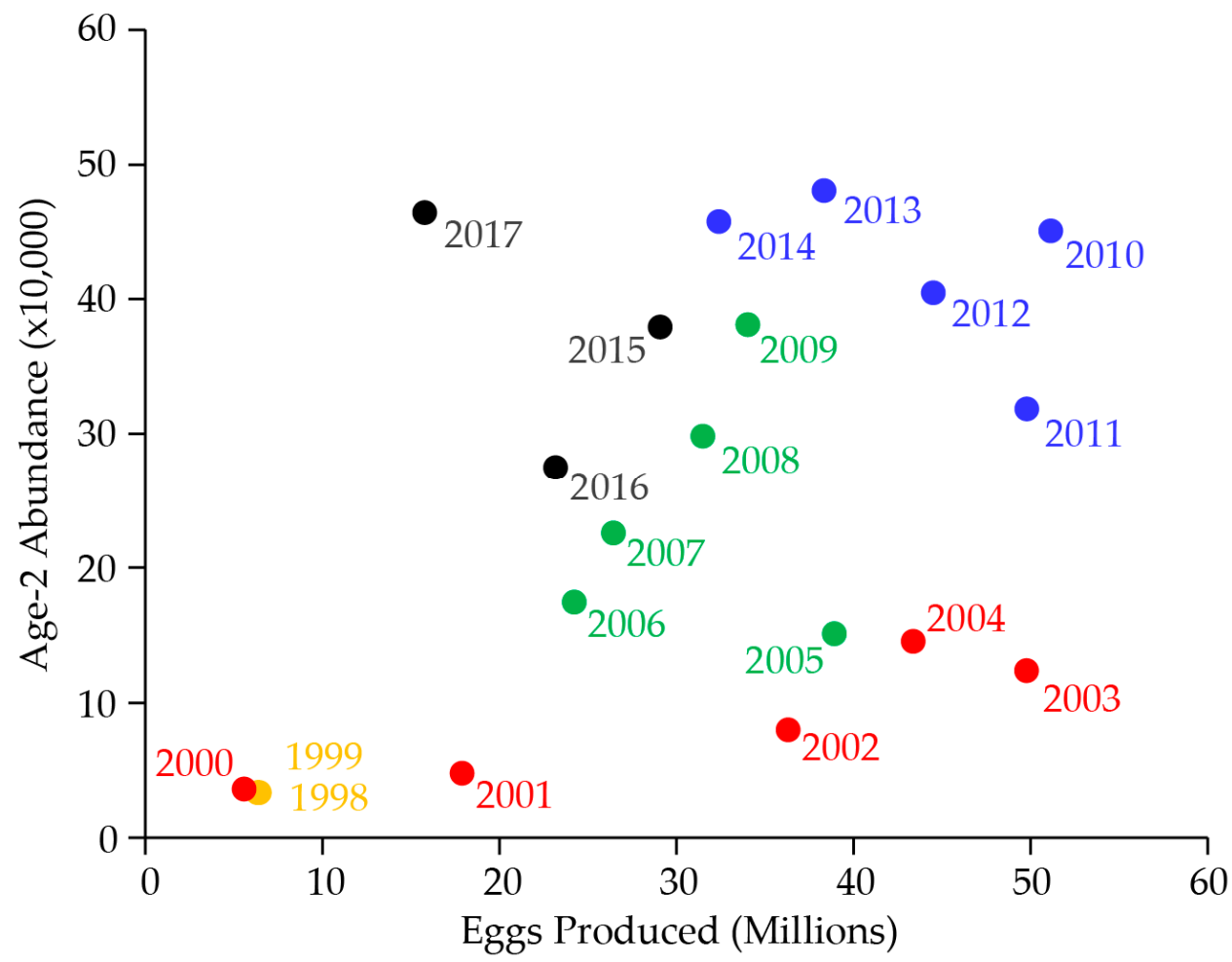

Figure 11. Age-2 lake trout abundances during 1998 to 2017 and the number of spawned eggs that produced these recruits two years previously estimated by a statistical catch-at-age (SCAA) assessment model [81]. Different colors represent 5-year periods of the lake trout suppression program described in text. Although fewer eggs were produced annually since lake trout population growth was curtailed in 2012, similar (or often greater) abundances of age-2 lake trout were recruited to the population, suggesting a compensatory response.

\section{Cutthroat Trout Population Response to Lake Trout Suppression}

The average cutthroat trout CPUE (during historical gillnetting assessments; Figure 1) was 37.8-48.7 per 100-m net night in the late-1980s and 41.9 in 1994, the year lake trout were first discovered (Figure 12A). Cutthroat trout CPUE then declined to 19.3 by 2004 (average of 8\% reduction per year) following more than a decade of predation pressure by lake trout. The lowest lake-wide cutthroat trout gillnetting CPUE was 10.9 in 2010, and other monitoring metrics (see below) also reached a minimum.

Cutthroat trout abundance declined precipitously until suppression efforts reached sufficient levels to reduce lake trout abundances in 2012 [41]. The number of cutthroat trout caught during annual long-term gillnetting assessments varied subsequently, with mean CPUE ranging from a low of 12.5 per 100-m net night in 2011 to highs of 27.3 and 26.4 in 2014 and 2018, respectively (Table A4, Figure 13). These CPUEs met established secondary desired conditions for cutthroat trout (CPUE $>26$; Table 1; Figure 12A). Size structure of the cutthroat trout population also varied during this period. The proportion of the long-term gillnetting assessment catch $\leq 280 \mathrm{~mm}$ (primarily age-2 individuals) was extremely low (16\%) in 2011 when lake trout predation pressure was high (Figure A8). Although large (> $400 \mathrm{~mm}$ ) individuals continued to dominate the cutthroat trout population during 2012 to 2019 when abundances of age $3+$ lake trout declined, cohorts of smaller cutthroat trout subsequently became a more common component of the population, indicating greater avoidance of lake trout predation. 

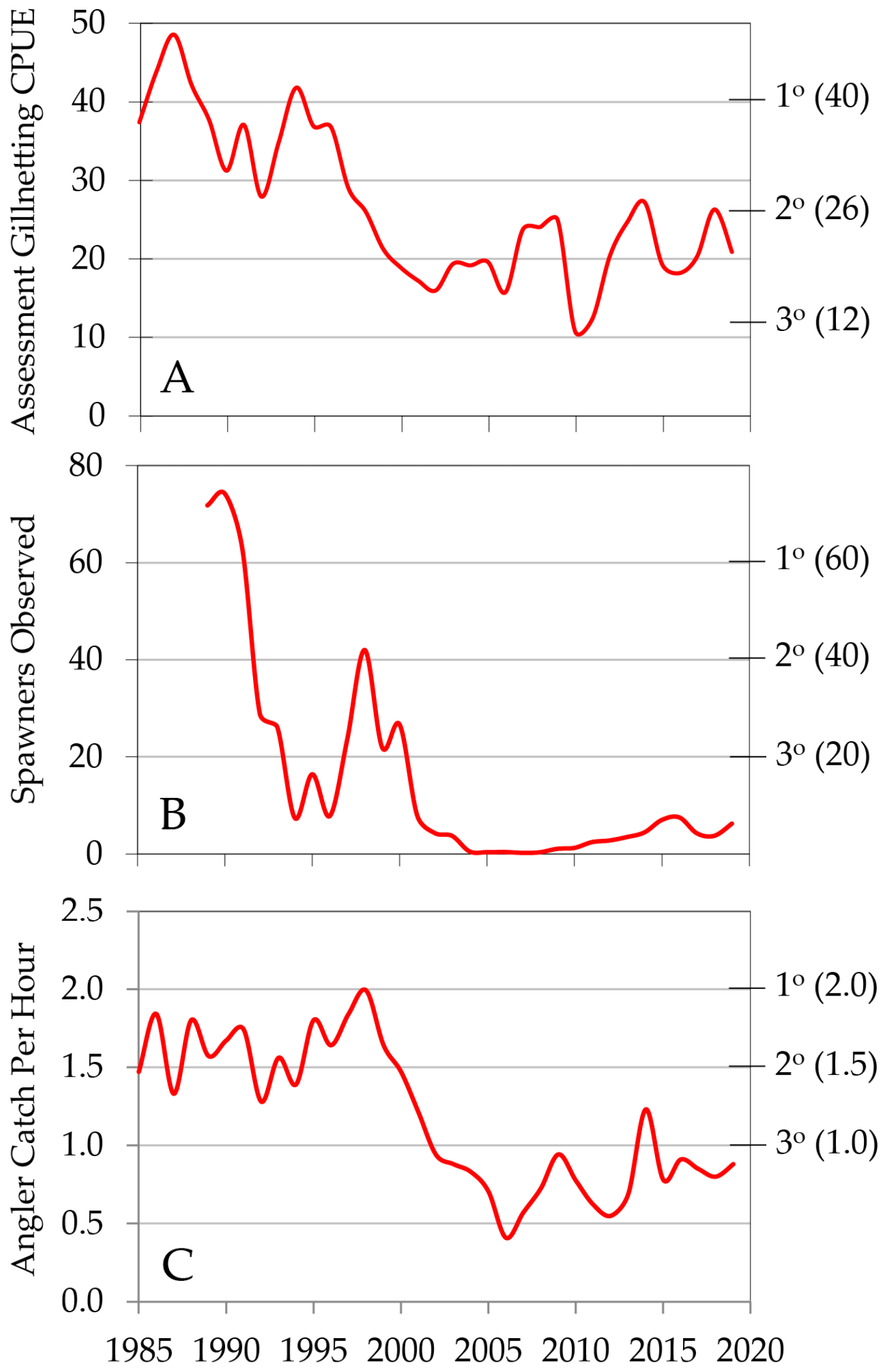

Figure 12. Cutthroat trout quantitative response variables monitored to assess the effects of conservation actions in the adaptive management strategy for Yellowstone Lake included the (A) catch-per-unit-effort (100-m net night) during within-lake gillnetting assessments, (B) observed during visual surveys of spawning streams, and (C) caught per hour by lake anglers, 1985-2019. Primary $\left(1^{\circ}\right)$, secondary $\left(2^{\circ}\right)$, and tertiary $\left(3^{\circ}\right)$ desired conditions are from the Native Fish Conservation Plan (Table 1) [90]. 


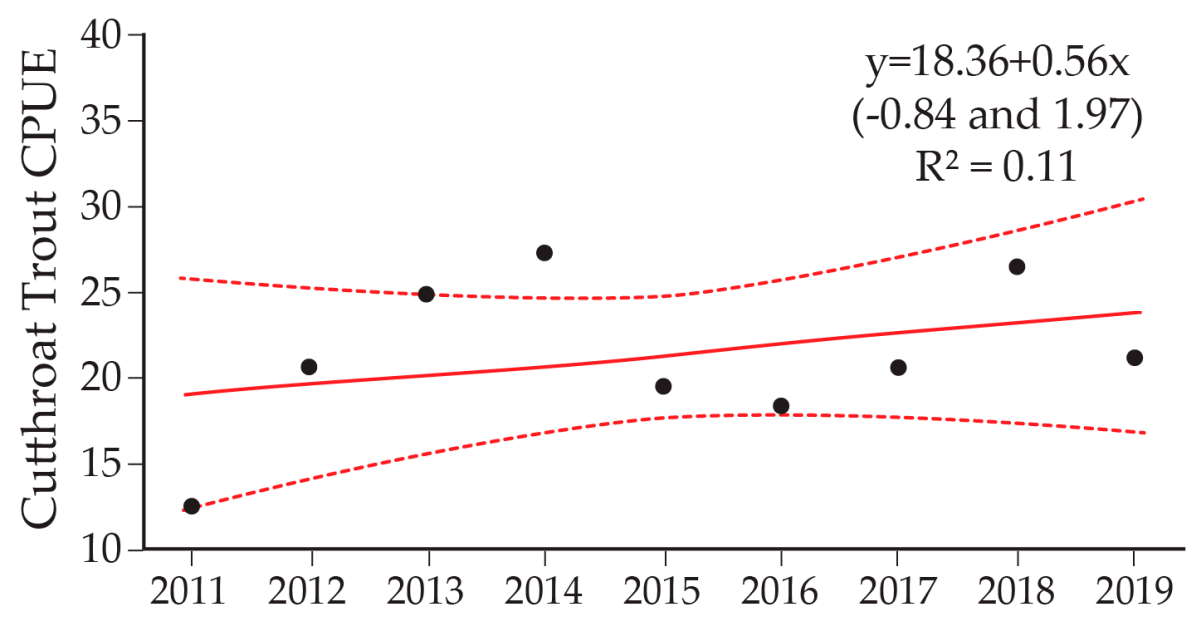

Figure 13. Catch-per-unit-effort (CPUE) of cutthroat trout during annual long-term gillnetting assessment monitoring on Yellowstone Lake, 2011-2019. The red line represents a simple linear regression model with 95\% confidence intervals (dashed lines). Numbers within parentheses are the upper and lower $95 \%$ confidence limits of the slope parameter estimate, indicating no temporal change in the CPUE response variable because the interval includes zero.

Spawning cutthroat trout abundances decreased significantly following the lake trout invasion as judged by visual surveys of 11 spawning streams conducted annually since 1989 (Figure 1) [51,105]. An average of 74 cutthroat trout was observed during each stream survey in 1990, compared to $\leq 1$ cutthroat trout during 2004 to 2010 (Figure 12B). Subsequently, spawning cutthroat trout increased slightly to a mean of 7.5 and 6.2 per survey in 2016 and 2019, respectively. Abundance increased in Little Thumb Creek, a tributary in the West Thumb near Grant (Figure 1), where more than 50 cutthroat trout were seen during a single visit in 2013, and more than 100 were seen during visits in 2014 and 2015. The number of fish observed in Little Thumb Creek after 2016 was about $80 \%$ of the total fish counted each spring at all of the visually-assessed spawning tributaries combined. Although the increased number of fish observed in Little Thumb Creek is encouraging, counts remained far below the primary or secondary desired conditions (means of 60 and 40 spawning cutthroat trout, respectively, observed per visit to all 11 of the visually-assessed spawning tributaries combined).

An estimated 68,000 cutthroat trout were caught by Yellowstone Lake anglers in 2019 at a catch rate of 0.9 fish per hour (Figure 12C). This catch rate was below the primary (2.0) and secondary (1.5) desired conditions (Table 1), which were the catch rates experienced during the 1980s and early 1990s. However, the average size of cutthroat trout caught in $2019(440 \mathrm{~mm})$ was much larger than caught prior to the lake trout invasion $(380 \mathrm{~mm})$. Although fewer fish were caught by anglers, the quality of the fish (from an anglers perspective) was much greater than in the past.

Lake trout predation was associated with a long-term shift in cutthroat trout lengths from dominance by small $(100-280 \mathrm{~mm})$ and midsized $(290-390 \mathrm{~mm})$ individuals to dominance by large individuals $(400+\mathrm{mm})$ in annual gillnetting assessments. The mean CPUE of small and midsized cutthroat trout declined from 18.6 per 100-m net night and 15.1, respectively, in the 1980s to just 6.9 and 3.9, respectively in the 2010s (Table A7, Figure 14A). Concurrently, the mean CPUE of large cutthroat trout nearly doubled, from 7.5 in the 1980s to 14.6 in the 2010s. Lake trout also caused increases in individual weights and condition of cutthroat trout. Although the average weight of small cutthroat trout slightly declined, the average weight of midsized and large cutthroat trout increased from $408.0 \mathrm{~g}$ and $682.8 \mathrm{~g}$, respectively, in the 1980s to $463.4 \mathrm{~g}$ and $1418.6 \mathrm{~g}$, respectively, in the 2010s (Table A7, Figure 14B). Relative weights (condition factors) of individual cutthroat trout also increased during this period. Mean relative weights of small, midsize, and large cutthroat trout were 58.8, 56.5, and 55.8, respectively, in the 1980s and increased to 68.4, 70.4, and 67.7, respectively, in the 2010s (Table A7, Figure 14C). Lower densities of cutthroat trout with higher individual weights and conditions should have higher fecundity [106], which should aid further recovery. 

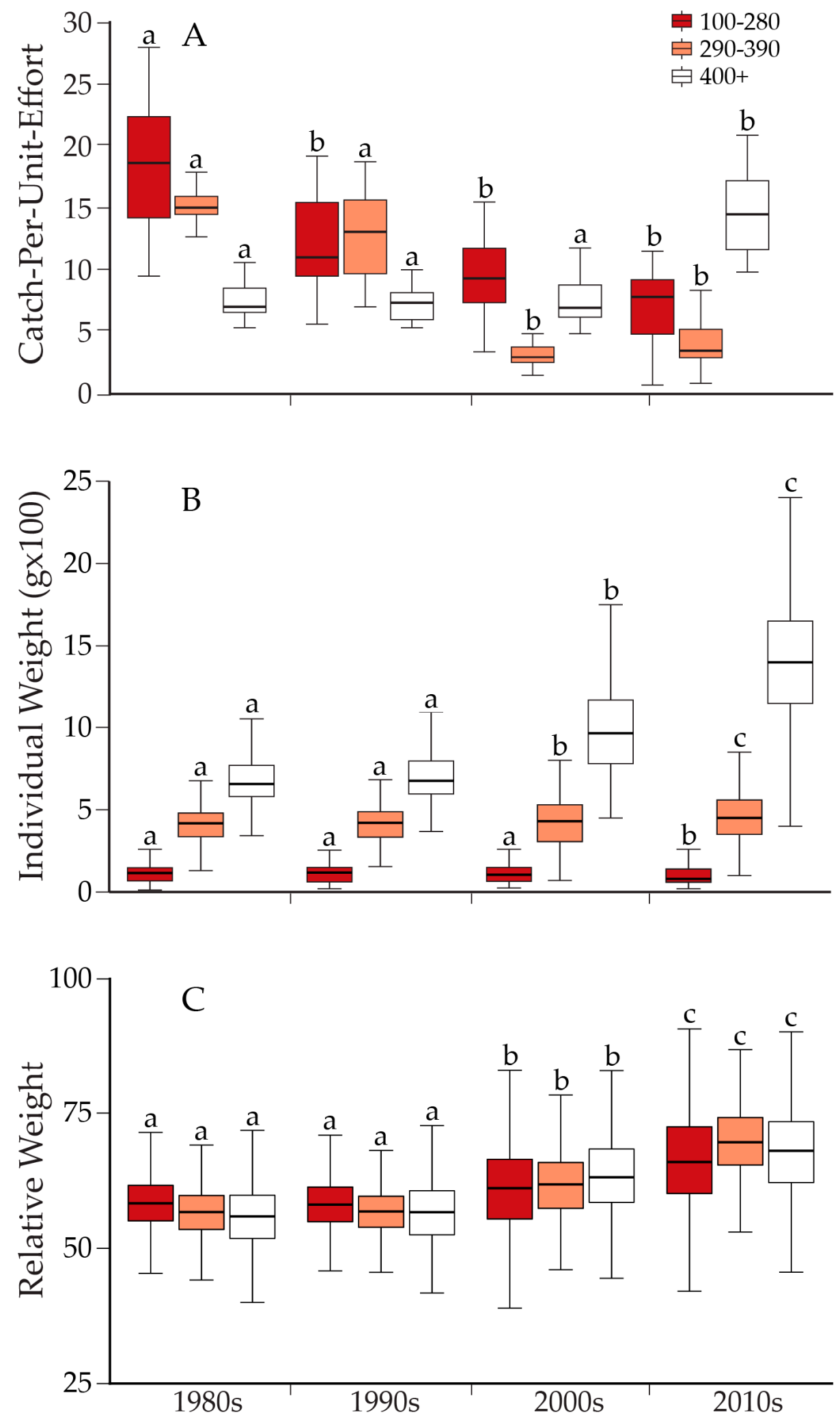

Figure 14. Mean (A) catch-per-unit-effort (100-m net night), (B) individual weight $(\mathrm{g} \times 100)$, and $(C)$ relative weight of each of three length groups $(\mathrm{mm})$ of cutthroat trout from annual gillnetting assessments during each decade (1980-2019) on Yellowstone Lake. Means marked with the same letters $(a-c)$ within each length group indicate no statistical difference among decades $(\alpha=0.05)$. 


\section{Ecological Response to Lake Trout Suppression}

Lake trout induced stress on cutthroat trout caused trophic shifts over four decades across multiple trophic levels both within and outside of Yellowstone Lake [41]. Hypothesized outcomes of lake trout reduction and cutthroat trout recovery were the return of trophic levels to natural, pre-lake trout conditions (Table A3). We therefore monitored components of the aquatic and terrestrial ecosystems to document the cascading changes that occurred after lake trout suppression.

The introduction of lake trout added a fourth trophic level [86] and resulted in cascading interactions within the aquatic food web of Yellowstone Lake, including shifts in cutthroat trout prey consumption and the biomass and individual lengths of zooplankton. When cutthroat trout were abundant in the 1980s, large-bodied cladocerans made up $80 \%$ of their diet [79]. After cutthroat trout declined in the 2000s, cladocerans made up only $11 \%$ of their diet, and cutthroat trout more frequently consumed amphipods, which made up 79\% of their diet by 2011 [107]. After cutthroat trout abundance declined and predation on large zooplankton was reduced, the biomass of small-bodied copepods declined and the biomass of large-bodied zooplankton increased within the pelagic zone [41]. In addition, the average length of large-bodied zooplankton increased. Increased grazing by the dominant large-bodied cladocerans following the decline of cutthroat trout resulted in lower phytoplankton biomass and increased water clarity [41]. Although zooplankton and phytoplankton communities can be early indicators of ecological change (because of rapid turnover rates), we did not observe any shifts of plankton to a pre-lake trout condition resulting from the suppression program.

Lake trout invasion caused substantial indirect effects [108] that extended to native avian and terrestrial animals, such as ospreys, eagles, and bears, because spawning cutthroat trout were an important high-energy food for them. Ospreys are obligate piscivores that cannot switch to alternative food sources in the absence of fish. Osprey nest densities declined concurrently with declines in cutthroat trout prey, from an average of 38 nests during 1987 to 1991 to 11 during 2004 to 2008 [52] and only 2 during 2015 to 2019 [41]. Nesting success during 1987 to 1991 averaged 59\% but declined to zero during 2008 to 2011 when no young ospreys were fledged from Yellowstone Lake nests. An average of $13 \%$ of osprey nests successfully fledged young during 2015 to 2019 . We did not observe an increase in osprey nest density resulting from the suppression program, but expected a lagged response to increased cutthroat trout abundance.

Four to six bald eagle nests were typically present on Yellowstone Lake during the 1960s and 1970s. The nest count increased to an average of 11 during 2004 to 2008 [52] but then declined to 8 nests by 2015 to 2019 [41]. A steady long-term decline in bald eagle nest productivity occurred over two decades concurrently with the lake-wide decline in cutthroat trout. During 1985 to $1989,56 \%$ of bald eagle nests on Yellowstone Lake successfully fledged young; however, nest success declined to zero in 2009 when prey fish abundance was low. Bald eagles are opportunistic feeders and increased consumption of alternative prey, including scavenging carnivore-provided carcasses and winterkill. Bald eagles were also observed preying on common loons and trumpeter swan cygnets, which have declined recently in Yellowstone National Park.

Grizzly and black bears are opportunistic feeders with flexible diets that consumed other foods available in the Yellowstone Lake area when cutthroat trout abundance was low [51,87]. No bear activity was found on surveyed spawning streams in 2008, 2009, or 2011 after cutthroat trout declined [41]. Compared to estimates obtained from 1997 to 2000, the number of grizzly bears visiting spawning streams a decade later (2007-2009) decreased by 63\%, and the number of black bears decreased by 64 to $84 \%$ [109]. Bear activity on spawning tributaries subsequently increased in response to the slight recovery of spawning cutthroat trout [41]. 


\section{Applied Research to Inform Decision Making}

Management actions to restore the Yellowstone Lake ecosystem were supported by science through a strong program of applied research. Primary university partners were Michigan State University, Montana State University, University of Montana, University of Vermont, University of Wyoming, and Utah State University. Agency research partners included Montana Department of Fish, Wildlife and Parks, U.S. Geological Survey, U.S. Fish and Wildlife Service, U.S. Department of Agriculture, and Wyoming Game and Fish Department.

Research identified Lewis Lake or other waters in the upper Snake River system as the source of lake trout introduced to Yellowstone Lake $[110,111]$ and identified the potential impacts the new predatory trophic level could have on the cutthroat trout and the ecology of the lake and tributary spawning streams $[79,86,112]$. As the cutthroat trout population declined, additional causal factors were investigated including Myxobolus cerebralis Hofer, 1903 (the causative agent of whirling disease), which was discovered in cutthroat trout from Yellowstone Lake in 1998 [113,114] and caused localized losses of cutthroat trout in Pelican Creek and the Yellowstone River downstream (Figure 1) [115-118]. Environmental factors influencing variation in cutthroat trout year class strength were also investigated. Persistent drought conditions were considered a strong contributing factor leading to cutthroat trout decline from the 1980s to the 2000s [51,92]. Studies also documented large-scale migrations, spawning locations (natal origins), and lake-wide movements of cutthroat trout [46,119].

After more than a decade of suppression gillnetting did not stop lake trout population growth, SCAA modeling of the lake trout population was conducted in the late 2000s to estimate lake trout demographics and establish gillnetting effort benchmarks that would result in $\lambda<1[80,102]$. An annual long-term monitoring protocol (long-term gillnetting assessment) was developed with sufficient power to detect changes in lake trout abundances over time [120]. Mark-recapture of tagged lake trout estimated population abundances and independently validated modeled lake trout abundance estimates [42]. The population model was updated annually and was critical for evaluating the efficacy of lake trout suppression relative to Native Fish Conservation Plan performance metrics [81,90].

Identification of lake trout spawning areas and movement patterns was critical for increasing the efficiency of the suppression program. Spawning habitat models, based on wave energy theory and geomorphology, suggested conditions for lake trout spawning habitat are patchy and exist in $<4 \%$ of the lake [62]. Acoustically-tagged "Judas" fish were used to document seasonal movement patterns, habitat use (including spawning), and guide gillnetting efforts. For example, telemetry of lake trout conducted over several years (2011-2016) using fixed array receivers revealed extensive movements throughout the lake, important migration corridors, and spawning habitats [98,121]. Active mobile telemetry (boat-mounted receivers) further refined lake trout spawning site locations [60] and provided gillnetting crews with real-time locations and depths of lake trout aggregations, which increased gillnetting catches [122]. Subsequently, putative lake trout spawning sites were searched for presence of gametes, and all verified sites were investigated using remotely operated vehicles or scuba diving to delineate substrate boundaries, estimate substrate sizes and depths, and document substrate types [59]. The early life history of lake trout in Yellowstone Lake was assessed to better understand potential vulnerabilities to alternative (complementary) suppression methods that target embryos or fry [123].

Ongoing research focused on the development of alternative suppression methods that target embryos on spawning sites and complement gillnetting (see below). Because the diets of lake trout and cutthroat trout shifted to dominance by amphipods following the cutthroat trout decline [107], research was conducted to better understand lake ecology related to large-scale carcass deposition (about 300,000 carcasses per year in lake areas deeper than $65 \mathrm{~m}$ ) and treatment of spawning sites with carcasses and organic pellets during autumn (see below). Ongoing efforts are underway to increase efficiency of monitoring cutthroat trout spawning abundances in tributaries using eDNA technology [124], detect congregations of lake trout using airborne lidar [125], and to further document effects of the lake trout and suppression actions on the lake and associated terrestrial ecosystems, including indirect effects on bears, birds, and river otters [41]. 


\section{Need for Complementary Methods that Target Multiple Life Stages}

The integrated pest management (IPM) approach to controlling invasive species uses a variety of suppression methods to target multiple life stages of invaders to maintain abundance levels below those causing harm [126-128]. The IPM approach has been most widely used in terrestrial systems to control agricultural pests $[129,130]$; however, a growing body of scientific evidence suggests that control of multiple life stages is required to suppress invasive fish populations over long time scales [131-133]. The suppression of sea lamprey in the Laurentian Great Lakes is an example of IPM in which chemical treatments, pheromone attractants, migration barriers, and other methods have been successfully used in combination [134-136]. The Yellowstone Lake gillnetting program curtailed lake trout population growth, but required extremely high levels of effort $[41,81]$. Because lake trout population growth rates are most sensitive to changes in age-0 survival $[18,137,138]$, we developed and experimentally assessed methods to reduce it, with the intent of implementing an IPM approach on Yellowstone Lake.

The search for suppression methods that could complement gillnetting began at Montana State University in 2004 by a mechanical and chemical engineering senior design team [139] and continued in 2008 with a comprehensive literature review [140]. Later, the effectiveness of high-pressure water [42], electricity [141], suction-dredging [142], tarping (suffocation), and use of lake trout carcasses [143,144] and organic (plant-based) pellets $[59,145,146]$ were evaluated for increasing lake trout embryo mortality in situ on Yellowstone Lake spawning sites. Additionally, chemical compounds (rotenone, sodium chloride, calcium carbonate, gelatin), sedimentation, fish carcasses, and organic (plant- and fish-based) pellets were evaluated in the laboratory [147]. To date, the most promising method for increasing lake trout embryo mortality was to intentionally degrade interstitial water quality. Treatment of spawning sites with lake trout carcasses or organic (soy and wheat gluten) pellets (Figure A9) induced organic decomposition and decreased dissolved oxygen concentrations at the substrate surface and $20 \mathrm{~cm}$ below the surface $[59,144,145]$. Biological oxygen demand of the decomposing organic materials caused dissolved oxygen to decline to $0 \mathrm{mg} / \mathrm{L}$ immediately after treatments and caused high embryo mortality within $200 \mathrm{~h}$.

Fourteen lake trout spawning sites have been located over the past 25 years by gillnetting, sonar, telemetry, and shoreline visual surveys [59]. These sites vary in size, depth, substrate type, and thermal characteristics (Figure 15), and are generally located near western shorelines in areas of relatively low fetch during the autumn spawning period (when prevailing winds are from the southwest, Figure 1). Because only a few weeks are available to safely work on Yellowstone Lake following the peak of lake trout spawning each autumn, we expanded the embryo suppression research to include a comprehensive treatment of a spawning site with organic pellets by helicopter (with long line and seeder/spreader) to better understand the logistical constraints that may be faced when attempting large-scale, multi-site applications in the future. During an October 2019 experimental treatment, all of the rocky substrate at the Carrington Island spawning site ( 0.5 ha; Figures 1 and A9) was treated with $18,000 \mathrm{~kg}$ of organic pellets in less than one day (Video S3). Fry traps placed at Carrington Island in spring 2020 captured no lake trout fry, indicating all lake trout embryos were likely killed by the treatment and recruitment from the site was completely eliminated. Relative to the expansive lake areas intensively gillnetted over a 22-week season ( $>60 \mathrm{~km}$ of gill nets set daily), lake trout embryo suppression targets relatively small sites during a period of 2-3 weeks in autumn where the majority of a future year class is concentrated. Broad-scale application of pellets in autumn may reduce lake trout recruitment and enhance population suppression as part of an IPM approach targeting multiple lake trout life stages because the area of the 14 verified spawning sites is only 11.4 ha $(0.03 \%$ of lake surface area) [59]. 


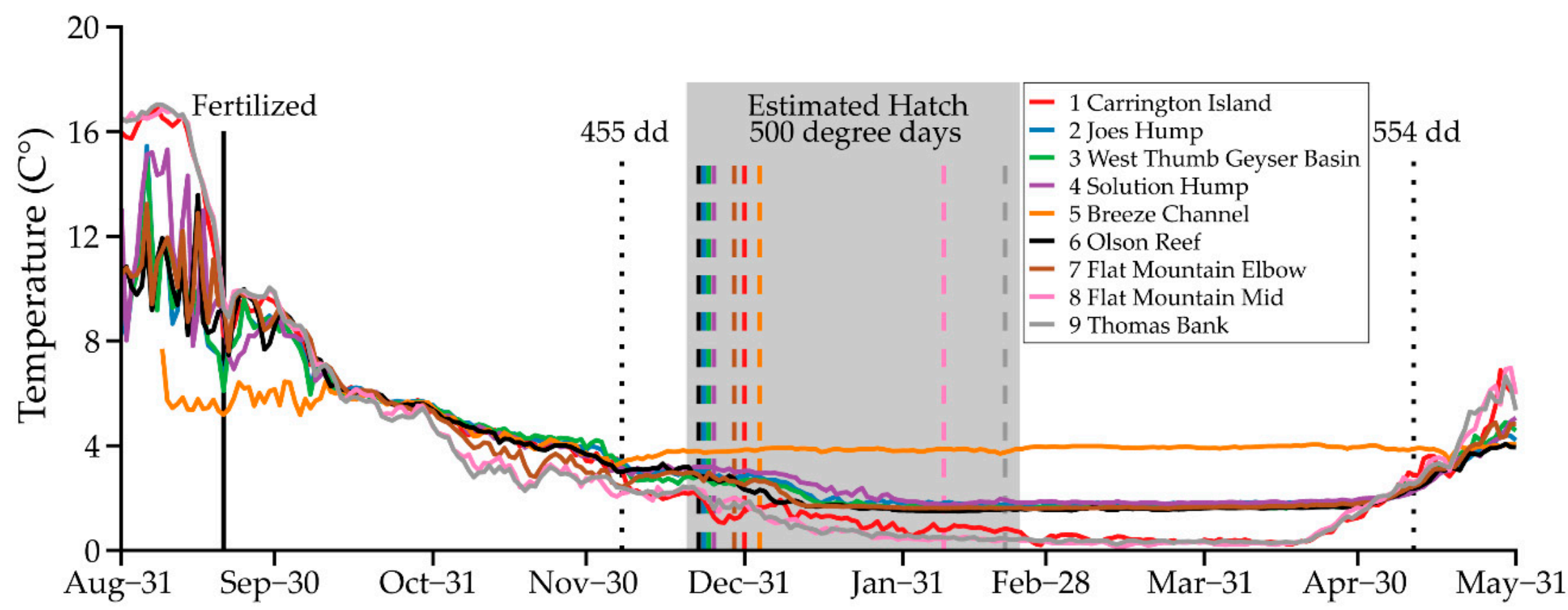

Figure 15. Water temperatures at the substrate of lake trout spawning sites in Yellowstone Lake during embryo fertilization, incubation, and hatching, September 2017-May 2018. Lake trout embryos require 455-554 degree days (dd) to hatch at $8{ }^{\circ} \mathrm{C}$ in the laboratory [147]. Dates of hatching at each site after $500 \mathrm{dd}$ are within shaded gray. Although cooling temperatures slow development [148], embryos fertilized by 20 September may hatch prior to Yellowstone Lake becoming ice covered in late-December, many months earlier than within their native range in the Great Lakes [149]. 


\section{Discovery of Nonnative Cisco in Yellowstone Lake}

A cisco (likely Coregonus artedi Lesueur, 1818), not native to Yellowstone Lake, was caught during lake trout gillnetting operations north of Stevenson Island during August 2019 (Figure 1). The cisco was a live immature female, age-3, caught in $50 \mathrm{~m}$ depth. Otolith microchemistry analysis indicated it was probably hatched in Yellowstone Lake, meaning that parents and siblings are probably present. Someone illegally introduced them because no possible natural pathway exists for this species to reach Yellowstone Lake. The nearest possible source populations are in Tiber and Ft. Peck [150] reservoirs in the Missouri River drainage of Northern Montana, at travel distances of $560 \mathrm{~km}(6+\mathrm{hrs})$ and $720 \mathrm{~km}$ (7+ hrs), respectively. We will implement monitoring for cisco population expansion using multimesh gillnetting of the lake pelagic zone, sampling for larvae, sampling for cisco eDNA, and by examining the stomachs of gillnetted lake trout. Cisco coevolved with lake trout and are their preferred prey in their native range within the Laurentian Great Lakes. If cisco become abundant in Yellowstone Lake, they could compete directly with cutthroat trout for zooplankton and other food resources, while providing additional prey for lake trout. Genetic analyses are being completed to confirm the fish caught in 2019 as C. artedi and possibly determine the source population for the illegal stocking.

\section{Discussion}

Yellowstone National Park is the site of successful restoration programs for iconic wildlife populations of American bison, gray wolves, grizzly bears, and trumpeter swans. Restoring cutthroat trout and the natural ecology of Yellowstone Lake, however, has been the most challenging restoration effort faced in the park's long history. The park was able to implement a suppression program that killed 3.35 million lake trout because scientific evidence strongly supported it, a must-harvest angler regulation was applied, numerous press releases and reports highlighted the urgent need, and a strong constituency for the lake trout fishery (that could have opposed suppression) never formed [151]. Moreover, the mission of the NPS is to preserve unimpaired the natural and cultural resources and values of the national park system for the enjoyment, education, and inspiration of this and future generations [152]. Cutthroat trout supported a fishery at Yellowstone Lake with historical importance and underpinned what had been the most intact naturally-functioning ecosystem in the lower 48 states. Therefore, allowing invasive predatory lake trout to persist and further degrade these nationally significant resources was not acceptable.

\subsection{Suppressing an Invasive Population Below Carrying Capacity}

Yellowstone Lake was perfectly suited for invasion and proliferation of predatory lake trout. The lake offered large expanses of deep, unoccupied habitat, devoid of co-evolved enemies [153], and rich in available resources [154] such as cutthroat trout forage that facilitated their establishment and expansion. Lack of thermal segregation (Figure A1) exacerbated interactions between lake trout and cutthroat trout throughout much of the year (mid-October through mid-June). Most of the lake $(64 \% ; 21,810 \mathrm{ha})$ is $<60 \mathrm{~m}$ deep [155], depths at which lake trout thrive. The lake is mesotrophic and more productive than most lakes within the native range of lake trout. Lake trout in Yellowstone Lake therefore grew rapidly [7], matured early, and had high fecundity [80] (r-selected traits) [156,157]. Suppression of this invasive lake trout population, which never reached carrying capacity $(K)[80,158]$, was therefore problematic. Managers use a total biomass yield threshold of $0.5 \mathrm{~kg} \mathrm{ha}^{-1} \mathrm{yr}^{-1}$ to avoid population collapse of lake trout fisheries in oligotrophic lakes in their native range [77,159]; yield densities of $95 \%$ of 145 populations in North America were $<3.42 \mathrm{~kg} \mathrm{ha}^{-1} \mathrm{yr}^{-1}$ [95]. We did not drive the population into decline until biomass yield (suppression) reached $4.4 \mathrm{~kg} \mathrm{ha}^{-1} \mathrm{yr}^{-1}$ in 2012 (Figure 6B). Therefore, gillnetting effort applied during the first 17 years $(1995-2011 ; 68 \%)$ of the 25 -year suppression program was insufficient to force the lake trout population into decline (i.e., $\lambda<1$; Figure 6B). 
Shifts in habitat use by the expanding lake trout population probably increased their survival and enhanced the complexity of our gillnetting suppression efforts. Although gillnetting effort greatly increased during 1995 to 2011, lake trout abundance increased in advance and the population expanded lake-wide (Figure 7). The lake trout population probably used the most productive habitats early in the invasion [160] because the species is adaptable and able to colonize new environments that satisfy their basic habitat requirements [161]. Discrete 'islands' of rocky substrates provided spawning opportunities to the expanding population as it radiated outward from the West Thumb. Island biogeography theory predicts that habitat use is driven by a balance between colonization and extirpation [162]. Predation is a potent force driving species sorting along environmental gradients in freshwater habitats [163]. High predation risk in one habitat may cause a shift to another habitat where risk is lower. Our 'predatory' gillnetting efforts on spawning sites discovered early in the program (e.g., Carrington Island) to target spawning adults may have forced straying and pioneering of new spawning sites in more remote locations of the lake that were unknown or not targeted. Site fidelity and selection pressure would cause greater use of the most successful spawning habitats by each successive generation. Successful spawning at a site may have been caused by better habitat quality (e.g., favorable thermal characteristics; Figure 15) or simply our lack of awareness of it, which precluded suppression gillnetting there.

Spatially disproportionate suppression effort may have afforded lake trout refuge in remote regions of Yellowstone Lake. Suppression gillnetting crews actively sought lake trout and placed gillnets to maximize catches throughout each season. These efforts expanded unhindered across Yellowstone Lake as the lake trout population expanded (Figure 7) but were limited in the Flat Mountain, South, and Southeast arms, which are within proposed wilderness (Figure 1); 30\% (6650 ha) of the 21,810 ha of Yellowstone Lake most suitable for gillnetting ( $<60 \mathrm{~m}$ deep) is within the proposed wilderness. Moreover, large lake trout move into the arms to prey upon juvenile cutthroat trout that emigrate from the upper Yellowstone River and other tributaries during late summer. Boat speeds within the arms were restricted to $<8 \mathrm{~km} \mathrm{hr}^{-1}$, and only nonmotorized boats (kayaks and canoes) were allowed in the far southern ends of the arms (including the delta of the upper Yellowstone River). Gillnetting in the arms was also deterred by long travel times and low catches, such that in 2013 only $14 \%$ of the total lake-wide gillnetting effort was applied there. The proposed wilderness was functioning as an aquatic (freshwater) protected area [164-166] limiting harvest of lake trout. We therefore completed a wilderness Minimum Requirements Analysis (MRA) in 2014 to suspend boating rules in the arms and allow aggressive targeting and gillnetting of lake trout lake-wide.

\subsection{Why are Lake Trout Resilient to Suppression Gillnetting on Yellowstone Lake?}

High early life history survival may buffer the effects of suppression gillnetting on the lake trout population. Sustainable exploitation of a fishery requires a reproductive surplus that can be removed [167-170]; harvest that exceeds this surplus can cause population collapse [171-173]. Survival of lake trout in their native range is regulated sensu [174] during early life stages [175,176] but survival of pre-recruits in Yellowstone Lake may be $4-6$ times higher [81] thereby requiring a $67 \%$ increase in gillnetting mortality at later stages to reduce population abundance $[80,81]$. The unoccupied habitat of Yellowstone Lake may provide lake trout a juvenile-survival advantage similar to that afforded to spawning common carp, arguably the most harmful invasive fish in the world, in predator-free, winterkill-prone shallow lakes $[177,178]$. Interstitial embryo predators such as sculpin Cottus spp. and crayfish Orconectes spp. $[179,180]$ and fry predators such as rock bass and yellow perch [181] that are common in the native range of lake trout do not exist in Yellowstone Lake, which is naturally species-depauperate because of its isolation and elevation. Larval lake trout can therefore stay on spawning sites later into the summer, feed more, and achieve greater maximum lengths before dispersing [123]. The lack of predation on pre-recruit lake trout in Yellowstone Lake may afford the population an 'ecological release' [81,182], thereby buffering it against our suppression efforts. 
High mortality of suppressed age classes may enhance survival of pre-recruit lake trout and add to population resilience through an an overcompensatory response to gillnetting mortality. Subjecting a life stage of a population to mortality can increase the abundance of other life stages and the total population [174]. Density-dependent processes can thereby confound removal efforts [183], resulting in positive population-level effects [132]. For example, intensive removal of age- 0 , juvenile, and adult smallmouth bass for 7 years from a north-temperate lake in New York, USA, reduced population biomass but increased population abundance, primarily by increasing juvenile abundance [184]. Size-selective mortality (i.e., uneven mortality across life stages) sensu [185] can elicit a similar response. For example, a large decrease in abundance of adult Eurasian perch resulted in a corresponding increase in juveniles [186]. Reduced competition among adult survivors increased somatic and reproductive growth, and juvenile survival was higher after release from cannibalism, collectively resulting in overcompensation. Similarly, the age composition of the Yellowstone Lake population shifted to predominantly younger fish as we increased gillnetting effort and targeted adult lake trout. Age-2 fish composed $26 \%-43 \%$ of total abundance during 1998 to 2004 , but increased to $48 \%-55 \%$ during 2014 to 2018 [81] and 69\% in 2019. Large-mesh gillnetting for 8 years (2012-2019) successfully reduced adult (age 6+) lake trout abundance by $79 \%$ and reduced total population biomass. However, abundance of age-2 fish did not change appreciably (Figure 10A). In Yellowstone Lake, per capita recruitment of lake trout at low levels of spawner abundance (Figure 11), pre-recruit survival [81], and maturation of age- 4 and older fish (Figure A6) are all high. All of these characteristics can result in overcompensation whereby population abundance increases in response to harvest [183,185]. Moreover, variation in adult biomass (gradient from high to low, 2012-2019) may have gradually reduced competition, increased fecundity, or allowed a shift from alternate-year to annual spawning. Cannibalism of embryos and other early life stages may also be reduced, further enhancing pre-recruit survival. Although the actual mechanisms are unknown, such compensatory responses may impede attempts to curtail lake trout population growth in Yellowstone Lake.

\subsection{Transition to Suppression of Multiple Lake Trout Life Stages}

The realization that high survival of pre-recruit lake trout may offset increased mortality of older age classes has heightened interest in an IPM approach targeting multiple life stages with complementary suppression methods on Yellowstone Lake. Specifically, intense treatment of lake trout spawning sites with carcasses or organic pellets may mimic habitat degradation in their native range to increase mortality of embryos or fry, or both, and thereby decrease recruitment, especially as fewer adults spawn at fewer sites. Location and characterization of primary spawning sites and assessment of the quantity and quality of embryo-deposition habitat and hatching success will be critical. Methods that focus on early life-history stages to disrupt and reduce lake trout reproduction and recruitment should prove effective if spawning continues to be concentrated in shallow $(<20 \mathrm{~m})$ lake areas.

Considerable uncertainty and built-in time lags deter significant reductions in suppression gillnetting effort. Currently, an estimated 95,000-100,000 gillnetting effort units will be required annually for 5 years to achieve a $90 \%$ probability of reducing lake trout abundance to 100,000 fish [81]. However, we expect that a combination of gillnetting and embryo suppression will probably be used to maintain the lake trout population below target levels, and population-level effects of embryo suppression cannot be distinguished from the effects of on-going gillnetting that targets lake trout adults. The SCAA model estimates that 55,000 effort units will be required to maintain suppression after the target abundance of 100,000 fish is met, but the estimate includes uncertainty, and any resurgence in lake trout (caused by premature or excessive reduction of suppression gillnetting) would not be detected until they recruit to our monitoring and suppression gillnets at age 2. A management correction would not occur until the following year, giving the lake trout population a full 3 years of recovery. Therefore, a reduction of suppression gillnetting should only be made with extreme caution and vigilant monitoring. 


\section{Conclusions}

Lake trout are being harvested from Yellowstone Lake at a greater rate than ever before anywhere on Earth [187]. This ecosystem restoration program illustrates that predatory fish invasions can be managed and controlled over large areas, even if total eradication may not be feasible. The process, however, requires a long-term commitment, is laced with uncertainty, and requires a great deal of collaboration. Program development, learning, demonstrating need, and building capacity to implement suppression actions at a large scale all require considerable time. Our adaptive management approach allows the program to move forward and implement conservation actions despite uncertainty in outcomes. Continuous learning from assessments and feedback obtained during annual science panel reviews are used to adjust lake trout suppression or other actions to progress towards desired conditions. This approach is used due to the varied environments and stressors (e.g., whirling disease and drought) impacting cutthroat trout in Yellowstone Lake, and the fact that some uncertainty exists in the possible responses by cutthroat trout and lake trout to future management actions. For example, although science-based findings indicate that lake trout population growth in Yellowstone Lake has been curtailed, uncertainty remains in the estimates of the number of years that high levels of suppression will need to be maintained to reduce the population to target levels $(100,000$ fish). Similarly, the rate of cutthroat trout recovery after the population is released from overriding lake trout impacts is also uncertain, as are the responses of avian and terrestrial wildlife. In the future, due to their use of shallow lake areas and dependence upon tributary streams, cutthroat trout may be more greatly harmed by climate-induced change than lake trout, which solely inhabit the comparatively stable, deep lake environment. The presence of cisco as a new, additional invader that functions as prey for lake trout (co-occurring exotic prey and exotic predator) sensu [35] further complicates matters. Lake trout suppression will become even more critical as these new threats emerge. Modeling of the cutthroat trout population is currently being conducted to better understand demographics and potentially refine objectives to include measures of stock biomass because lake trout predation resulted in a shift in cutthroat trout size structure to dominance by large fish (Video S4). Performance metrics will continue to be refined and monitored to track system responses to lake trout suppression, and the results will continue to be used to make adaptations and adjust management actions each year.

\section{Materials and Methods}

\subsection{Lake Trout Suppression Netting}

Up to six boats (Figure A4) were used to capture lake trout with sinking gillnets during late-May to mid-October 1995-2019 [97,188]. Suppression netting consisted of small-mesh (25 to $38 \mathrm{~mm}$ ) and large-mesh (44 to $76 \mathrm{~mm}$ ) bar measure gill nets targeting lake trout at depths typically greater than $20 \mathrm{~m}$ to reduce cutthroat trout bycatch. Nets were set shallower than $20 \mathrm{~m}$ at known spawning locations during peak spawning activity in autumn. Gill net soak time was typically three to four nights. Annual effort (effort unit $=100$-m net per night) was 249 units in 1995 and increased to highs of 97,397 units and 96,971 units in 2018 and 2019, respectively (Figure 6A). Trap nets were also used during 2010 to 2013 to target large lake trout (i.e., $>450 \mathrm{~mm}$ ) [42,188]. Four to 10 trap nets were deployed at fixed locations throughout Yellowstone Lake each year. The netted lake trout were cut to puncture air bladders and then returned to deep ( $>65 \mathrm{~m}$ ) regions of Yellowstone Lake.

\subsection{Cutthroat Trout and Lake Trout Gillnet Assessment}

Within Yellowstone Lake, cutthroat trout population metrics and individual characteristics (e.g., relative abundance, size structure, body condition) were assessed by standardized gillnetting programs. In mid-September during 1980 to 2010, gillnet surveys were conducted at 11 fixed sites throughout the lake (historical gillnetting assessment; Figure 1) [72,106]. At each site, five sinking experimental gill nets were set overnight perpendicular to shore in shallow water. Nets were set $100 \mathrm{~m}$ 
apart with the near-shore end about $1.5 \mathrm{~m}$ deep. Nets were $1.5 \mathrm{~m}$ in height and $38 \mathrm{~m}$ length, consisting of $7.6 \mathrm{~m}$ panels of $19-$ to $51-\mathrm{mm}$ bar measure.

In 2011, a new protocol (long-term gillnetting assessment) was developed and implemented through 2019 to encompass monitoring of both cutthroat trout and lake trout. During the long-term gillnetting assessment program, 24 sites throughout the lake were sampled each year with a split-panel design to maximize spatial coverage and power for detecting temporal change [120]. Thirty-six sites were originally selected randomly with 12 designated to be revisited each year and the remaining 24 split into two panels of 12 sites each that were revisited every other year on an alternating basis. The sampling occurred after establishment of the lake thermocline during early August with a total of six experimental gill nets per site (Figure 1). At each site, a small-mesh and large-mesh sinking gill net were set overnight at each of three depth strata [epilimnion ( 3 to $10 \mathrm{~m}$ ), metalimnion (10 to $30 \mathrm{~m}$ ), and hypolimnion $(>40 \mathrm{~m})$ ]. Small-mesh gill nets were $2 \mathrm{~m}$ in height and $76 \mathrm{~m}$ length, consisting of 13.7-m panels of 19- to 51-mm bar measure. Large-mesh gillnets were $3.3 \mathrm{~m}$ in height and $68.6 \mathrm{~m}$ length, consisting of 13.7-m panels of 57- to $89-\mathrm{mm}$ bar measure. Gill nets were set perpendicular to shore and nets within a stratum were set parallel $100 \mathrm{~m}$ apart. Only the gillnets set in the shallow stratum were used to assess cutthroat trout. Gillnets at all three depth strata were used to assess lake trout.

Both the mid-September historical gillnetting assessment and August long-term gillnetting assessment were conducted for a period of 4 years to ensure that cutthroat trout mean CPUE and size structure were similar and a continuous dataset among the years of both monitoring programs could be compared, 1980-2019 (Figure 12). Discontinuing the historical gillnetting assessment of cutthroat trout in 2010 allowed additional time for NPS crews to focus on lake trout suppression activities during the critical autumn spawning period.

Relative weight for individual cutthroat trout was calculated using the equation $\mathrm{Wr}=(\mathrm{W} / \mathrm{Ws})^{*} 100$, where $\mathrm{W}=$ measured weight and $\mathrm{Ws}=$ standard weight predicted from a cutthroat trout (lentic) standard weight equation $\log 10$ (Weight $)=a+b{ }^{*} \log 10$ (Length), where $a=-5.192$ and $b=3.086$ [189]. One-way analysis of variance (ANOVA) was used to compare mean CPUE, individual weight, and relative weight for each length class among the four decades $(\alpha=0.05)$. If a statistical difference among decade means was detected, a post hoc Tukey's honestly significant difference multiple comparison procedure was used to test for differences between decade means. Data were manipulated using the "dplyr" package [190] in Program R and analyzed using Program R [191].

Relative condition $(\mathrm{Kn})$ for individual lake trout was calculated using the equation $\mathrm{Kn}=\left(\mathrm{W} / \mathrm{W}^{\prime}\right)^{*} 100$, where $\mathrm{W}=$ measured weight and $\mathrm{W}^{\prime}$ = predicted weight of a fish of the same length from a lake trout average weight-length equation $\log 10($ Weight $)=a+b * \log 10$ (Length), where $a=-5.589$ and $\mathrm{b}=3.210$ [95]. One-way analysis of variance (ANOVA) was used to compare mean Kn for each length class among the five time periods $(\alpha=0.05)$. If a statistical difference among means was detected, a post hoc Tukey's honestly significant difference multiple comparison procedure was used to test for differences between means of each time period.

Lake trout length at 50\% maturity (L50) was estimated from lake trout (female $\mathrm{n}=1766$; male $\mathrm{n}=2812$ ) captured in gillnets in Yellowstone Lake during 1996 to 2019. Maturity stages (i.e., immature or mature) were assigned macroscopically, proportion of mature lake trout by $10 \mathrm{~mm}$ length bins was calculated, and sex-specific logistic regression models were fit to the proportional data. Length at 50\% maturity was estimated from the model's inflection point and confidence intervals (95\%) of L50 were estimated with bootstrapping using the bootCase() function from the "car" package [192] in program R [191]. Data were manipulated using the "dplyr" package [190] in Program R and analyzed using Program R.

\subsection{Cutthroat Trout Tributary Spawner Assessment}

Visual surveys for spawning cutthroat trout and bear activity were conducted annually during 1989 to 2019 on 9 to 11 tributaries located along the western side of Yellowstone Lake between Lake and Grant (Figure 1) [51,105]. Spawning reaches were delineated on each tributary, and the standardized 
reaches were walked in an upstream direction once each week from May to July. Observed cutthroat trout were counted, and the activity by black bears and grizzly bears was estimated by noting the presence of scat, parts of consumed trout, fresh tracks, and/or bear sightings. The average number of spawning cutthroat trout observed per visit was obtained by dividing the total observed (in all 9 to 11 tributaries combined, through the entire spawning period) by the number of surveys conducted.

\subsection{Cutthroat Trout and Lake Trout Angler Catch}

Because of its remote location, largely roadless (proposed wilderness) shoreline, and the short period of time (approximately 4 months annually) that local supportive facilities are open (campgrounds, gas stations, marinas), the angler effort on Yellowstone Lake is extremely low as compared to other large lakes in the Western U.S. We estimated angler effort and success via a report card distributed to all anglers when purchasing a special use permit for fishing in the park [72]. Annually, approximately 4000 anglers (10\% of all park anglers) have voluntarily completed and returned cards for analysis. More than 9000 anglers fished Yellowstone Lake in 2019.

\subsection{Lake Trout Population Modeling and Gillnetting Effort Benchmarks}

The Yellowstone Lake lake trout population is assessed annually using an integrated SCAA assessment model that incorporates time-series of data from both suppression netting and long-term gillnetting assessment programs [80,102]. The SCAA model is age structured and encompasses ages ranging from age 2 to age 17, with the last age class an aggregate group including all fish age 17 and older. Age 2 is the age of recruitment in the SCAA model because younger age lake trout are not frequently captured in suppression or assessment gillnets. The SCAA model uses time-series of observations from the suppression gillnet program, the suppression trapnet program that ran from 2010 to 2013, and the long-term gillnetting assessment. The SCAA model generates predictions of abundances at age of the lake trout population based on model-based estimates of recruitment levels, abundances-at-age in the first assessment year, and underlying mortality levels for the different fishery components in operation and assumed natural mortality levels. Conditional on the predicted abundances at age, the SCAA model predicts suppression and assessment netting harvest and age-composition of harvest, which are compared to observed values. Predictions from the SCAA model can then be combined with other population descriptors (e.g., length at age, length-weight relationships, maturation at age, fecundity) to estimate the stock-recruitment relationship for the lake trout population, total and age-specific fishery yield, total and age-specific population biomass. In combination, the analyses and modeling results provided a robust time series prediction of the lake trout population, which in turn, can be used to gauge the success of the suppression program in decreasing lake trout abundance in Yellowstone Lake and strategize future efforts.

Annually, the SCAA model is used to estimate the amount of gillnetting effort required to cause an abundance decline in the lake trout population (i.e., $\lambda<1$ ) and, in recent years (2017-2019), to achieve an abundance goal of 100,000 lake trout. These estimates have been critical for the restoration program as they have dictated the numbers of crews, boats, nets, and other gear (and therefore funding) needed to achieve suppression targets. The amount of housing required for the crews, which is extremely limited in the Yellowstone Lake area, was also driven by the suppression targets established from the assessment modeling. Annually, information gained from monitoring and suppression gillnetting was used to lengthen the time series of the data components that feed into the SCAA model. In turn, the annual gillnetting effort benchmarks evolve as the model updates the most recent estimates of abundances and mortalities (Figure 6A).

\subsection{Monitoring for Ecological Response}

A goal of the Yellowstone Lake ecosystem restoration is to restore the natural ecological role of native cutthroat trout. The lake trout-induced stress on cutthroat trout caused trophic shifts over the past four decades across multiple trophic levels both within and outside of Yellowstone Lake [41]. 
Hypothesized outcomes of lake trout reduction and cutthroat trout recovery is that these altered trophic levels will revert to their natural, pre-lake trout conditions (Table A3). To document the cascading changes that may occur due to lake trout suppression, we monitor several components of the aquatic and terrestrial ecosystems.

Aquatic ecological monitoring occurred during ice-free seasons and included measurements of zooplankton density, biomass, and size from samples collected at four lake regions (Main Basin, West Thumb, South Arm, and Southeast Arm; Figure 1) [41]. Phytoplankton biomass was estimated using chlorophyll a, and light transmission was measured using a Secchi disk in West Thumb. The thermal structures of Yellowstone Lake (e.g., isotherm depths) were measured in the West Thumb using a multiparameter sonde (Hydrolab Surveyor). Temperature was also measured routinely at the lake's surface. Lake surface levels, ice-on and -off dates, and outlet discharge (Yellowstone River at Fishing Bridge) were also obtained annually.

Avian and terrestrial consumers of cutthroat trout were annually monitored to document potential recovery. The number of breeding pairs and nesting success was determined for bald eagle and osprey populations each breeding season by surveying all forested areas up to $1 \mathrm{~km}$ from the Yellowstone Lake shoreline, connected tributaries, and forested islands using a fixed-wing Super Cub airplane [41]. Bear use of spawning cutthroat trout was documented during visual surveys for spawning cutthroat trout (as described above) on 9 to 11 tributaries located along the western side of Yellowstone Lake. Activity by black bears and grizzly bears was estimated by noting the presence of scat, parts of consumed trout, fresh tracks, and/or bear sightings along spawning stream corridors.

\subsection{Permits and Ethical Aspects}

This study was performed under the auspices of Montana State University Institutional Animal Care and Use Protocol 2018-68. Any use of trade, product, or firm names is for descriptive purposes only and does not imply endorsement by the U.S. Government.

Supplementary Materials: The following are available online, Video S1 (Native cutthroat trout and the Yellowstone Lake Ecosystem, http://doi.org/10.5281/zenodo.3820758); Video S2 (Gillnetting invasive lake trout http://doi. org/10.5281/zenodo.3829258); Video S3 (Organic pellet application to Carrington Island spawning site http: //doi.org/10.5281/zenodo.3829479); and Video S4 (Angling for restored native cutthroat trout http://doi.org/10.5281/ zenodo.3829613).

Author Contributions: Conceptualization, T.M.K., M.E.R.; methodology, J.L.A., P.E.B., C.R.D., P.D.D., B.D.E., R.E.G., D.J.M., T.J.S., L.M.T., A.V.Z.; formal analysis, T.M.K., P.E.B., T.O.B., C.S.G., J.M.S., N.A.T.; investigation, J.L.A., P.E.B., C.R.D., P.D.D., B.D.E., R.E.G., D.J.M., T.J.S., L.M.T., A.V.Z.; supervision, P.J.W.; project administration, T.M.K., P.J.W.; funding acquisition, T.M.K., J.D.D., D.P.S.; writing —original draft preparation, T.M.K.; writing-review and editing by all authors. All authors have read and agreed to the published version of the manuscript.

Funding: This research was funded by Yellowstone Forever, grant number G-022; George B. Storer Foundation; Greater Yellowstone Coalition; Idaho Council of Trout Unlimited; Montana Council of Trout Unlimited; Montana Fish, Wildlife and Parks; Montana State University; National Parks Conservation Association; National Park Foundation; University of Wyoming; U.S. Fish and Wildlife Service; U.S. Geological Survey; Whirling Disease Initiative, Montana Water Center; Wyoming Council of Trout Unlimited; Wyoming Game and Fish Department; Wyoming Wildlife and Natural Resource Trust; and the U.S. National Park Service, Yellowstone National Park.

Acknowledgments: Special thanks to the nearly five hundred seasonal NPS biological science technicians, Student Conservation Association (SCA) interns, contract gillnetting captains and crewmembers, and long-term volunteers that contributed to restoration of Yellowstone Lake over the past 25 years, This project greatly benefitted from management by Wayne Brewster, Jennifer Carpenter, David Hallac, Lynn Kaeding, Daniel Mahony, James Selgeby, S. Thomas Olliff, and John Varley, with strong support by park superintendents Michael Finley, Suzanne Lewis, Daniel Wenk, and Cameron Sholly. Partners advancing restoration science include Lindsey Albertson, Julie Alexander, Michelle Briggs, Kerry Gunther, Billie Kerans, Dominique Lujan, Thomas McMahon, Silvia Murcia, Alex Poole, James Ruzycki, Douglas Smith, Kole Stewart, and Jacob Williams. Along with NPS and contract staff the SCA program (www.theSCA.org) has provided immeasurable support for recovering cutthroat trout. The Rocky Mountains Cooperative Ecosystems Studies Unit (www.cfc.umt.edu/cesu) facilitated numerous agreements supporting critical research. We thank all Scientific Review Panel members 1995-2019-recent members include Michael Hansen, Michael Jones, Christopher Luecke, Ellen Marsden, Patrick Martinez, Jason Stockwell, Jack Williams, and Daniel Yule. Christopher Downs provided comments that greatly improved this manuscript. We greatly thank Allison Klein for producing all manuscript figures. 
Conflicts of Interest: The authors declare no conflict of interest. The funders had no role in the design of the study; in the collection, analyses, or interpretation of data; in the writing of the manuscript, or in the decision to publish the results

Dedication: This case study is dedicated to the memory of Jacqueline J. Koel, loving mother of Todd Koel, who sadly lost her decade-long battle with Parkinson's disease during preparation of this manuscript.

\section{Appendix A}

Table A1. Common and scientific names of birds, fishes, and mammals referred to in text for locations within Yellowstone National Park and elsewhere.

\begin{tabular}{|c|c|c|c|}
\hline Location & Taxon & Common Name & Scientific Name \\
\hline \multicolumn{4}{|c|}{ Yellowstone } \\
\hline & \multirow[t]{4}{*}{ Birds } & bald eagle & Haliaeetus leucocephalus (Linnaeus, 1766) \\
\hline & & common loon & Gavia immer (Brunnich, 1764) \\
\hline & & osprey & Pandion haliaetus (Linnaeus, 1758) \\
\hline & & trumpeter swan & Cygnus buccinator Richardson, 1832 \\
\hline & \multirow[t]{6}{*}{ Fishes } & $\operatorname{cisco}^{1}$ & Coregonus artedi Lesueur, 1818 \\
\hline & & lake chub & Couesius plumbeus (Agassiz, 1850) \\
\hline & & lake trout & Salvelinus namaycush (Walbaum, 1792) \\
\hline & & longnose sucker & Catostomus catostomus (Forster, 1773) \\
\hline & & redside shiner & Richardsonius balteatus (Richardson, 1836) \\
\hline & & Yellowstone cutthroat trout $^{2}$ & Oncorhynchus clarkii bouvieri (Jordan and Gilbert, 1883) \\
\hline & \multirow[t]{5}{*}{ Mammals } & American bison & Bison bison (Linnaeus, 1758) \\
\hline & & American black bear & Ursus americanus Pallas, 1780 \\
\hline & & gray wolf & Canis lupus Linnaeus, 1758 \\
\hline & & grizzly bear & Ursus arctos (Linnaeus, 1758) \\
\hline & & North American river otter & Lontra canadensis (Schreber, 1777) \\
\hline \multicolumn{4}{|l|}{ Elsewhere } \\
\hline & \multirow[t]{6}{*}{ Fishes } & common carp & Cyprinus carpio Linnaeus, 1758 \\
\hline & & Eurasian perch & Perca fluviatilis Linnaeus, 1758 \\
\hline & & rock bass & Ambloplites rupestris (Rafinesque, 1817) \\
\hline & & sea lamprey & Petromyzon marinus Linnaeus, 1758 \\
\hline & & smallmouth bass & Micropterus dolomieu Lacepède, 1802 \\
\hline & & yellow perch & Perca flavescens (Mitchill, 1814) \\
\hline
\end{tabular}

${ }^{1}$ Likely C. artedi, confirmation by genetic analysis in process. ${ }^{2}$ Subspecies designation. 
Table A2. Public support played an important role in the Yellowstone Lake ecosystem restoration program. Outreach occurred via multiple sources using a wide range of media types. Information exchange with the public and program involvement by students, volunteers, interns, agency partners, and conservation organization staff were critical for highlighting the consequences of lake trout and helping to secure funding. This timeline identifies key events or changes that occurred, the public outreach that resulted, and links to available literature or other information online.

\begin{tabular}{|c|c|c|c|}
\hline Year & Key Changes or Events & Public Outreach & Available URL \\
\hline \multirow[t]{3}{*}{1994} & Lake trout first discovered by an angler & NPS press releases & $\begin{array}{l}\text { https://www.latimes.com/archives/la-xpm-1994-11-22-mn- } \\
\text { 424-story.html }\end{array}$ \\
\hline & US $\$ 10,000$ reward offered for information leading to arrest & Lake trout wanted poster & http://doi.org/10.5281/zenodo.3873385 \\
\hline & Lake trout must-kill angling regulation implemented & YNP angling regulations & $\begin{array}{l}\text { https://www.nps.gov/yell/planyourvisit/upload/ } \\
\text { 20FishReg_web.pdf }\end{array}$ \\
\hline \multirow[t]{2}{*}{1995} & Scientific panel review guides management response & Report to the NPS Director & $\begin{array}{l}\text { https://www.nps.gov/parkhistory/online_books/yell/trout_ } \\
\text { invasion.pdf }\end{array}$ \\
\hline & Public awareness of lake trout effect on birds and mammals & Numerous articles & https://www.nps.gov/articles/ys-25-1-shorts.htm \\
\hline \multirow[t]{3}{*}{1996} & Lake trout telemetry locates spawning areas & Graduate research programs & https://www.researchgate.net/publication/34007273 \\
\hline & Student Conservation Association, beginning of long-term support & Internships on suppression crews & https://www.thesca.org/ \\
\hline & Yellowstone Science, century of fisheries research and management & Special issue for the public & https://www.nps.gov/yell/learn/upload/YS_4_4_sm.pdf \\
\hline 1997 & Applied research documents lake trout effects on cutthroat trout & Peer-reviewed publication & $\begin{array}{l}\text { https://doi.org/10.1890/1051-0761(2003)013\{[\}0023: } \\
\text { EOILTO\{]\}2.0.CO;2 }\end{array}$ \\
\hline \multirow[t]{2}{*}{1998} & Whirling disease discovered in cutthroat trout & Peer-reviewed publication & https://doi.org/10.1577/H05-031.1 \\
\hline & Yellowstone fishes: ecology, history, and angling in the park & Book released & https://www.nps.gov/yell/learn/bookstore.htm \\
\hline 1999 & Angler creel survey conducted to estimate lake trout catch & Interviews with lake anglers & https://www.nps.gov/yell/learn/fishreports.htm \\
\hline 2000 & Park visitor perceptions of lake trout evaluated & Yellowstone Science article & https://www.nps.gov/yell/learn/upload/YS_9_2_sm.pdf \\
\hline \multirow[t]{2}{*}{2001} & Gillnetting enhanced by specialized boat and dedicated crews & NPS technical report on-line & https://www.researchgate.net/publication/237614952 \\
\hline & Cutthroat trout catch-and-release only angling regulation & YNP angling regulations & $\begin{array}{l}\text { https://www.nps.gov/yell/planyourvisit/upload/ } \\
\text { 20FishReg_web.pdf }\end{array}$ \\
\hline \multirow[t]{2}{*}{2002} & YNP native fish conservation reports for each year & Reports produced for the public & https://www.nps.gov/yell/learn/fishreports.htm \\
\hline & YNP fly fishing volunteer program initiated & Volunteers interact with NPS biologists & https://www.nps.gov/articles/ys-25-1-shorts.htm \\
\hline 2003 & Extent of whirling disease effect on cutthroat trout documented & Graduate research programs & https://doi.org/10.3354/dao071191 \\
\hline 2004 & Montana State University, College of Engineering, Senior design & Investigate suppression alternatives & http://doi.org/10.5281/zenodo.3873394 \\
\hline 2005 & Drought effects on cutthroat trout documented & Peer-reviewed publication & $\begin{array}{l}\text { https://doi.org/10.1577/1548-8446(2005)30\{[\}10: } \\
\text { NLTRIY\{]\}2.0.CO;2 }\end{array}$ \\
\hline
\end{tabular}


Table A2. Cont.

\begin{tabular}{|c|c|c|c|}
\hline Year & Key Changes or Events & Public Outreach & Available URL \\
\hline 2006 & Barbless hook only angling regulation implemented & YNP angling regulations & $\begin{array}{l}\text { https://www.nps.gov/yell/planyourvisit/upload/ } \\
\text { 20FishReg_web.pdf }\end{array}$ \\
\hline 2006 & Yellowstone Science, cutthroat trout conservation & Special issue for the public & https://www.nps.gov/yell/learn/upload/YS_14_2_sm.pdf \\
\hline 2007 & Regional drought highlights potential effects of climate change & YNP angling closures to park waters & https://www.ncdc.noaa.gov/sotc/drought/200708 \\
\hline \multirow[t]{3}{*}{2008} & Scientific panel review following cutthroat trout decline & Report to YNP Superintendent & $\begin{array}{l}\text { https://www.nps.gov/yell/planyourvisit/upload/gresswell_ } \\
\text { final_updated_1_2010.pdf }\end{array}$ \\
\hline & Initiate research regarding alternate suppression techniques & Comprehensive literature review & $\begin{array}{l}\text { http://files.cfc.umt.edu/cesu/NPS/MSU/2008/08Zale_ } \\
\text { YELL_trout\%20embryos_lit\%20review.pdf }\end{array}$ \\
\hline & Weird but true! Researcher proposes jello to kill lake trout & Montana State University news release & https://nypost.com/2008/12/29/weird-but-true-2347/ \\
\hline \multirow[t]{2}{*}{2009} & Contract gillnetting pilot phase begins & YNP native fish program report & https://www.nps.gov/yell/learn/fishreports.htm \\
\hline & Public scoping meetings for plan/ environmental assessment & Meetings and on-line comment period & $\begin{array}{l}\text { https://parkplanning.nps.gov/projectHome.cfm? } \\
\text { projectID=30504 }\end{array}$ \\
\hline \multirow[t]{4}{*}{2010} & Native fish conservation plan/EA completed & Adaptive management plan & $\begin{array}{l}\text { https://parkplanning.nps.gov/projectHome.cfm? } \\
\text { projectID=30504 }\end{array}$ \\
\hline & Lake trout statistical-catch-at-age model created & Graduate research programs & https://doi.org/10.1139/cjfas-2019-0306 \\
\hline & Aquatic trophic cascade documented & Peer-reviewed publication & https://doi.org/10.1577/T09-151.1 \\
\hline & Public meetings at YNP gateway communities & Annually for information exchange & https://www.nps.gov/yell/learn/news/19013.htm \\
\hline \multirow[t]{4}{*}{2011} & Scientific panel reviews implemented annually & Reports to YNP Superintendent & $\begin{array}{l}\text { https://www.nps.gov/yell/planyourvisit/upload/Lake_ } \\
\text { Trout_Suppression_Workshop_LowRes_Accessible.pdf }\end{array}$ \\
\hline & Contract gillnetting fully implemented annually & YNP native fish program report & https://www.nps.gov/yell/learn/fishreports.htm \\
\hline & Lake trout telemetry studies reinitiated & Public interpretive website & $\begin{array}{l}\text { https://www.usgs.gov/centers/norock/science/yellowstone- } \\
\text { lake-acoustic-biotelemetry-project-home-page }\end{array}$ \\
\hline & Yellowstone Lake Workgroup formed & Memorandum of Understanding & http://doi.org/10.5281/zenodo.3873432 \\
\hline \multirow[t]{2}{*}{2012} & Yellowstone Forever US\$1,000,000 grant began annually & Save the Yellowstone cutthroat trout & https://www.yellowstone.org/what-we-do/native-fish/ \\
\hline & Trout Unlimited bloggers tour for conservation writers & Articles published on-line & $\begin{array}{l}\text { http://www.sippingemergers.com/2012/08/setting-stage. } \\
\text { html?m=1 }\end{array}$ \\
\hline 2013 & Native fish conservation program website & Public interpretive website & $\begin{array}{l}\text { https://www.nps.gov/yell/learn/management/native-fish- } \\
\text { conservation-program.htm }\end{array}$ \\
\hline 2013 & Fund-raising by donating a lake trout telemetry tag & Trout Unlimited public website & $\begin{array}{l}\text { https://eastyellowstonetu.org/images/ } \\
\text { savetheyellowstonecutthroat_2.html }\end{array}$ \\
\hline
\end{tabular}


Table A2. Cont.

\begin{tabular}{|c|c|c|c|}
\hline Year & Key Changes or Events & Public Outreach & Available URL \\
\hline & Wyoming Wildlife and Natural Resource Trust grant US $\$ 771,000$ & Wyoming Trout Unlimited & https://wwnrt.wyo.gov/ \\
\hline & Grizzly bear predation links loss of native trout to migratory elk & Peer-reviewed publication & https://doi.org/10.1098/rspb.2013.0870 \\
\hline & University science partner press releases & Articles published on-line & $\begin{array}{l}\text { http://www.montana.edu/news/mountainsandminds/ } \\
\text { article.html?id=11921 }\end{array}$ \\
\hline 2014 & Public outreach for project support enhanced & Lake trout suppression FAQ website & $\begin{array}{l}\text { https://www.usgs.gov/centers/norock/science/faq-invasive- } \\
\text { lake-trout-yellowstone-lake }\end{array}$ \\
\hline 2015 & Trout Unlimited document supporting science & Lake trout suppression FAQ report & $\begin{array}{l}\text { http://wyomingtu.org/wp-content/uploads/2014/03/ } \\
\text { Science-Supporting-Management-of-Yellowstone-Lake- } \\
\text { Fisheries.pdf }\end{array}$ \\
\hline \multirow[t]{3}{*}{2016} & NPS centennial celebration & Heightened public awareness & https://yellowstone.co/pdfs/centennial2016.pdf \\
\hline & Outdoor Writers Association of America Conference & Tour and articles about the program & $\begin{array}{l}\text { https://owaa.org/2014/02/owaa-announces-location-2016- } \\
\text { annual-conference/ }\end{array}$ \\
\hline & Lake trout carcasses used to kill embryos on spawning sites & Graduate research programs & https://doi.org/10.1002/nafm.10259 \\
\hline \multirow[t]{2}{*}{2017} & Yellowstone Science, native fish conservation issue & Special issue for the public & $\begin{array}{l}\text { https://www.nps.gov/articles/series.htm?id=87AF9117- } \\
\text { 08B4-46BB-97B9C28B37A85BB2 }\end{array}$ \\
\hline & Sound of science in Yellowstone audio series & Podcast available online & $\begin{array}{l}\text { https://www.nps.gov/yell/learn/photosmultimedia/ } \\
\text { onefishtwofish.htm }\end{array}$ \\
\hline \multirow[t]{4}{*}{2018} & Journey through Yellowstone's aquatic ecosystems & Interpretive video available online & $\begin{array}{l}\text { https: } \\
\text { //www.nps.gov/yell/learn/nature/fishaquaticspecies.htm }\end{array}$ \\
\hline & Realization that lake trout may have invaded naturally & Several articles by the media & $\begin{array}{l}\text { https://www.jhnewsandguide.com/news/environmental/ } \\
\text { could-lake-trout-swim-to-y-stone/article_0625cb12-8782- } \\
\text { 59bd-a942-93653e5328e5.html }\end{array}$ \\
\hline & Effects of actions to suppress lake trout on lake ecology & Graduate research programs & http://www.mtcfru.org/ \\
\hline & Organic pellets used to kill embryos on spawning sites & Peer-reviewed publication & https://doi.org/10.1002/tafs.10208 \\
\hline \multirow[t]{2}{*}{2019} & Fly Fishing Film Tour features cutthroat trout return & Spring public film series & $\begin{array}{l}\text { https://www.tu.org/blog/fly-fishing-film-tour-features-the- } \\
\text { return/ }\end{array}$ \\
\hline & Partnership support of the restoration program continues & Trout Unlimited on-line articles & $\begin{array}{l}\text { https://www.tu.org/blog/lake-trout-on-the-decline-in- } \\
\text { yellowstone-lake/ }\end{array}$ \\
\hline \multirow[t]{2}{*}{2019} & Magazine articles highlighting suppression efforts & National Geographic and others & $\begin{array}{l}\text { https://www.nationalgeographic.com/animals/2019/06/ } \\
\text { how-to-eradicate-yellowstone-lake-trout/ }\end{array}$ \\
\hline & Public radio programming & Montana Public Radio & $\begin{array}{l}\text { https://www.mtpr.org/post/non-native-lake-trout- } \\
\text { numbers-declining-yellowstone-officials-say }\end{array}$ \\
\hline
\end{tabular}


Table A2. Cont.

\begin{tabular}{llll}
\hline Year & \multicolumn{1}{c}{ Key Changes or Events } & \multicolumn{1}{c}{ Public Outreach } & \multicolumn{1}{c}{ Available URL } \\
\hline & Regional and national print media & Cody Enterprise and others & $\begin{array}{l}\text { https://www.codyenterprise.com/news/local/article_ } \\
\text { bd6ba2a0-93b9-11ea-b91b-2f3aadaca730.html }\end{array}$ \\
\hline Lake trout-induced indirect ecological effects documented & Heightened international awareness & https://advances.sciencemag.org/content/5/3/eaav1139 \\
\hline 2020 & Full length documentary film on the lake restoration effort & Video segments with this article & https://zenodo.org/record/3829613\#.XtVlU2hKiUk \\
\hline Program updates made available to the public & NPS press releases continue & https://www.nps.gov/yell/learn/news/19053.htm \\
\hline Lake trout suppression on-line information updated & Public interpretive website & https://www.nps.gov/yell/learn/nature/lake-trout.htm \\
\hline Yellowstone Forever fund-raising partnership continues & A race against time donor website & https://www.yellowstone.org/trout/ \\
\hline Scientific panel review results highlighted & Numerous articles on-line & $\begin{array}{l}\text { https://www.tu.org/blog/science-panel-excited-about- } \\
\text { numbers-on-yellowstone-lake/ }\end{array}$ \\
\hline Two Ocean Pass: Alternative hypothesis for lake trout invasion & Peer-reviewed publication & https://doi.org/10.3390/w12061629 \\
\hline Environmental assessment to expand spawning site treatments & Public scoping on-line anticipated & \\
\hline Global Covid-19 pandemic & Restoration program continues &
\end{tabular}


Table A3. Conceptual ecosystem model for the Yellowstone Lake ecosystem restoration. Cells with " $X$ " are hypothesized linkages between agents of change, stressors on native fish, and ecosystem responses. Italic text with asterisks $\left(^{*}\right)$ and darkly shaded cells indicate elements addressed by the restoration program.

\begin{tabular}{|c|c|c|c|c|c|c|c|c|c|c|c|}
\hline AGENTS OF CHANGE & 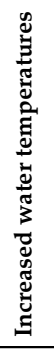 & 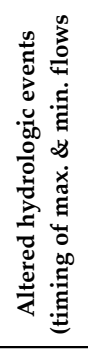 & 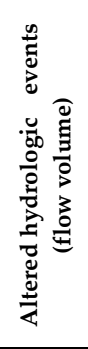 & 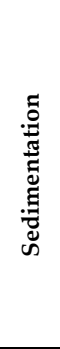 & 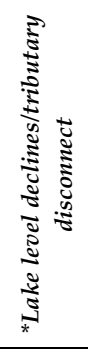 & 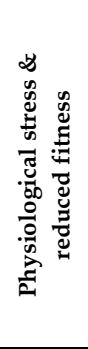 & 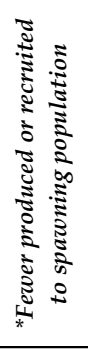 & 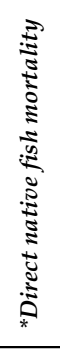 & 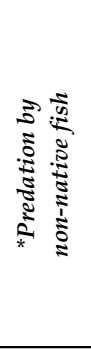 & 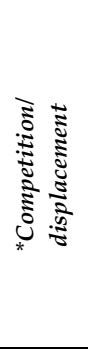 & 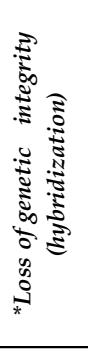 \\
\hline Increasing temperature (air) & $x$ & $x$ & $x$ & & $x$ & $x$ & $x$ & & & & \\
\hline *Changing precipitation patterns (snowpack, runoff) & $x$ & $x$ & $x$ & & $x$ & $x$ & $x$ & & & & \\
\hline Wildland Fire Frequency Increased & $x$ & $x$ & $x$ & $x$ & & & $x$ & & & & \\
\hline \multicolumn{12}{|l|}{ Biological Introductions } \\
\hline${ }^{*}$ Historical fish stocking by management & & & & & & & $x$ & $x$ & $x$ & $x$ & $x$ \\
\hline *Stocking of fish illegally (lake trout) & & & & & & & $x$ & $x$ & $x$ & $x$ & \\
\hline Aquatic nuisance species (New Zealand mudsnails) & & & & & & & $x$ & & & $x$ & \\
\hline \multicolumn{12}{|l|}{ Angling } \\
\hline Intentional illegal harvest & & & & & & & $\mathrm{x}$ & $x$ & & & \\
\hline Mis-identification resulting in harvest & & & & & & & $x$ & $x$ & & & \\
\hline Catch \& release mortality & & & & & & & $x$ & $x$ & & & \\
\hline \multicolumn{12}{|l|}{ Park Infrastructure/Operations } \\
\hline Fire suppression & & & & & & $x$ & & & & & \\
\hline Backcountry trails \& campsites & & & & $x$ & & $x$ & & & & & \\
\hline Land management (stock use, herbicide treatments) & & & & $x$ & & $x$ & & & & & \\
\hline Road improvements & & & & $x$ & & $x$ & & & & & \\
\hline Water treatment facilities & & $x$ & $x$ & & & $x$ & & & & & \\
\hline \multicolumn{12}{|l|}{ Local Physical/Chemical Forces } \\
\hline Natural geothermal inputs & $x$ & & & & & $x$ & & & & & \\
\hline
\end{tabular}


Table A3. Cont.

\begin{tabular}{|c|c|c|c|c|c|c|c|c|c|c|c|}
\hline ECOSYSTEM RESPONSE & 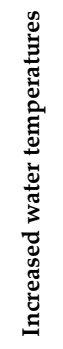 & 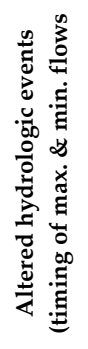 & 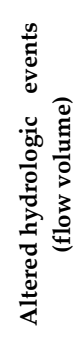 & 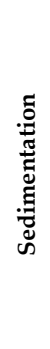 & 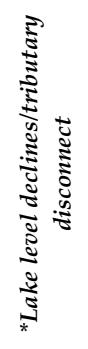 & 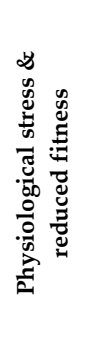 & 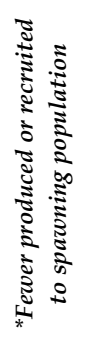 & 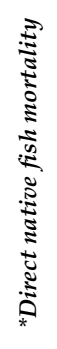 & 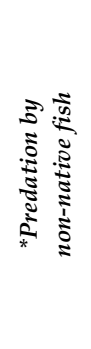 & 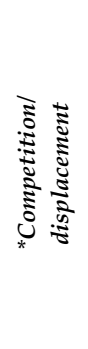 & 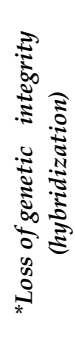 \\
\hline${ }^{*}$ Nutrient flux/transport altered & & & & & $x$ & $x$ & & $x$ & $X$ & $X$ & \\
\hline \multicolumn{12}{|l|}{ Productivity/Biomass Change } \\
\hline${ }^{*}$ Primary production (algae) availability reduced & & & & & $x$ & $x$ & & $x$ & $x$ & $X$ & \\
\hline *Secondary production (inverts/zooplankton) availability altered/reduced & $x$ & $x$ & & $x$ & $x$ & $x$ & & $x$ & $x$ & $x$ & \\
\hline *Secondary production (fish) availability altered/reduced & $x$ & $\mathrm{x}$ & & $x$ & $x$ & $x$ & & $x$ & $x$ & $\mathrm{x}$ & \\
\hline \multicolumn{12}{|l|}{ Fish Functional Role as Secondary Consumers } \\
\hline $\begin{array}{l}\text { *Shift from invertivore (invert consumer) to piscivore (fish } \\
\text { consumer/predator) }\end{array}$ & & & & & & & & $x$ & $X$ & $x$ & \\
\hline \multicolumn{12}{|l|}{ Fish Life History Strategy } \\
\hline *Shift in spawning timing & $x$ & $x$ & & & & & & & & & $x$ \\
\hline${ }^{*}$ Disrupt migration and/or shift in spawning location & & & $x$ & $x$ & $x$ & & $x$ & & & & $x$ \\
\hline *Habitat volume (niche) available reduced & $\mathrm{x}$ & & $x$ & $x$ & $x$ & & & & & $x$ & \\
\hline \multicolumn{12}{|l|}{ Avian/Terrestrial Tertiary Consumers } \\
\hline${ }^{*}$ Displacement of grizzly bears from spawning streams & & & & & $x$ & & & $x$ & $x$ & $x$ & \\
\hline${ }^{*}$ Decline in native trout use by ospreys and eagles & & & & & $\bar{x}$ & & & $x$ & $x$ & $x$ & \\
\hline *Increased physiological stress on river otters & & & & & $x$ & & & $x$ & $x$ & $x$ & \\
\hline
\end{tabular}


Table A4. Mean catch-per-unit-effort (CPUE, 100-m net night) of cutthroat trout and lake trout during annual long-term gillnetting assessments on Yellowstone Lake, 2011-2019, with lower (Lwr) and upper (Upr) 95\% confidence limits (CL).

\begin{tabular}{ccccccc}
\hline \multicolumn{3}{c}{ Cutthroat Trout } & \multicolumn{3}{c}{ Lake Trout } \\
\hline Year & YCT CPUE & Lwr 95\% CL & Upr 95\% CL & LKT CPUE & Lwr 95\% CL & Upr 95\% CL \\
\hline 2011 & 12.46 & 8.10 & 16.82 & 4.44 & 2.91 & 5.97 \\
2012 & 20.53 & 16.38 & 24.68 & 3.28 & 2.20 & 4.36 \\
2013 & 24.82 & 19.03 & 30.61 & 2.80 & 2.00 & 3.60 \\
2014 & 27.30 & 22.19 & 32.41 & 4.86 & 3.39 & 6.33 \\
2015 & 19.42 & 14.66 & 24.18 & 3.89 & 3.00 & 4.78 \\
2016 & 18.28 & 14.18 & 22.38 & 2.79 & 1.94 & 3.64 \\
2017 & 20.38 & 15.99 & 24.77 & 2.80 & 2.08 & 3.52 \\
2018 & 26.44 & 20.50 & 32.38 & 1.96 & 1.44 & 2.48 \\
2019 & 20.96 & 16.82 & 25.10 & 2.00 & 1.11 & 2.89 \\
\hline
\end{tabular}

Table A5. Mean annual total abundance and biomass, and abundances of age-2, age-3 to age-5, and age-6+ lake trout at the start of the year from 2012 through 2019 with lower (Lwr) and upper (Upr) 95\% confidence limits (CL) estimated using a statistical catch-at-age (SCAA) model [81].

\begin{tabular}{|c|c|c|c|c|}
\hline Year & Lake Trout & Mean & Lwr 95\% CL & Upr $95 \%$ CL \\
\hline 2012 & Abundance Total & 925,208 & 771,271 & $1,125,280$ \\
\hline 2013 & & 798,996 & 652,429 & 965,909 \\
\hline 2014 & & 774,569 & 633,884 & 943,216 \\
\hline 2015 & & 872,537 & 700,626 & $1,071,490$ \\
\hline 2016 & & 877,724 & 706,840 & $1,089,630$ \\
\hline 2017 & & 764,868 & 594,113 & 936,550 \\
\hline 2018 & & 572,550 & 449,699 & 741,077 \\
\hline 2019 & & 673,983 & 493,012 & 976,925 \\
\hline 2012 & Abundance Age-2 & 450,672 & 364,999 & 560,782 \\
\hline 2013 & & 318,640 & 249,647 & 397,507 \\
\hline 2014 & & 404,864 & 315,551 & 496,958 \\
\hline 2015 & & 480,961 & 372,384 & 597,922 \\
\hline 2016 & & 457,865 & 353,324 & 571,199 \\
\hline 2017 & & 379,099 & 289,469 & 476,558 \\
\hline 2018 & & 274,512 & 207,561 & 373,254 \\
\hline 2019 & & 463,958 & 313,814 & 688,536 \\
\hline 2012 & Abundance Age- 3 to 5 & 416,814 & 336,620 & 510,974 \\
\hline 2013 & & 433,844 & 353,892 & 538,683 \\
\hline 2014 & & 333,291 & 268,885 & 417,800 \\
\hline 2015 & & 355,516 & 280,185 & 448,171 \\
\hline 2016 & & 386,503 & 301,593 & 490,933 \\
\hline 2017 & & 363,205 & 271,289 & 454,582 \\
\hline 2018 & & 281,511 & 213,664 & 363,813 \\
\hline 2019 & & 197,681 & 146,741 & 282,689 \\
\hline 2012 & Abundance Age-6+ & 57,722 & 41,025 & 72,130 \\
\hline 2013 & & 46,512 & 31,696 & 60,086 \\
\hline 2014 & & 36,414 & 24,458 & 48,976 \\
\hline 2015 & & 36,060 & 25,506 & 50,249 \\
\hline 2016 & & 33,356 & 23,762 & 48,202 \\
\hline 2017 & & 22,563 & 14,961 & 32,736 \\
\hline 2018 & & 16,527 & 11,088 & 25,040 \\
\hline 2019 & & 12,345 & 7991 & 20,163 \\
\hline 2012 & Biomass Total & 432,017 & 343,977 & 521,873 \\
\hline 2013 & & 398,020 & 314,683 & 488,371 \\
\hline 2014 & & 382,138 & 298,369 & 469,323 \\
\hline 2015 & & 342,273 & 269,421 & 428,070 \\
\hline 2016 & & 321,580 & 257,333 & 414,412 \\
\hline 2017 & & 290,201 & 223,262 & 369,658 \\
\hline 2018 & & 229,509 & 179,299 & 304,616 \\
\hline 2019 & & 196,675 & 147,708 & 282,073 \\
\hline
\end{tabular}


Table A6. Mean relative condition (Kn) with lower (Lwr) and upper (Upr) 95\% confidence limits (CL) for three length classes $(\mathrm{mm})$ of lake trout captured in Yellowstone Lake during periods of lake trout population growth (1995-1999, 2000-2004, and 2005-2009) and periods of population decline (2010-2014 and 2015-2019).

\begin{tabular}{ccccc}
\hline Length Class (mm) & Time Period & Mean Kn & Lwr 95\% CL & Upr 95\% CL \\
\hline $200-280$ & $1995-1999$ & 120.31 & 117.00 & 123.61 \\
& $2000-2004$ & 120.03 & 110.22 & 129.83 \\
& $2005-2009$ & 121.36 & 119.22 & 123.50 \\
$2010-2014$ & 115.74 & 114.32 & 117.16 \\
& $2015-2019$ & 116.26 & 114.96 & 117.56 \\
\hline $290-390$ & $1995-1999$ & 112.06 & 111.52 & 112.60 \\
& $2000-2004$ & 112.86 & 111.83 & 113.89 \\
& $2005-2009$ & 116.59 & 114.10 & 119.08 \\
& $2010-2014$ & 111.88 & 111.02 & 112.75 \\
& $2015-2019$ & 113.93 & 112.90 & 114.95 \\
\hline \multirow{2}{*}{$400+$} & $1995-1999$ & 102.78 & 102.23 & 103.33 \\
& $2000-2004$ & 102.04 & 100.23 & 103.84 \\
& $2005-2009$ & 106.21 & 105.11 & 107.32 \\
& $2010-2014$ & 107.38 & 106.45 & 108.31 \\
& $2015-2019$ & 111.78 & 110.20 & 113.35 \\
\hline
\end{tabular}

Table A7. Mean catch-per-unit-effort (100-m net night), individual weight (g), and relative weight with lower (Lwr) and upper (Upr) 95\% confidence limits (CL) of each of three length groups (mm) of cutthroat trout from annual gillnetting assessments during each decade (1980-2019) on Yellowstone Lake.

\begin{tabular}{|c|c|c|c|c|c|}
\hline Cutthroat Trout & Length Class (mm) & Decade & Mean & Lwr 95\% CL & Upr $95 \%$ CL \\
\hline \multirow[t]{12}{*}{ Catch-Per-Unit-Effort } & \multirow[t]{4}{*}{$100-280$} & 1980s & 18.63 & 14.27 & 22.99 \\
\hline & & $1990 \mathrm{~s}$ & 11.95 & 8.25 & 15.64 \\
\hline & & $2000 s$ & 9.43 & 6.77 & 12.09 \\
\hline & & $2010 s$ & 6.88 & 4.34 & 9.42 \\
\hline & \multirow[t]{4}{*}{$290-390$} & $1980 \mathrm{~s}$ & 15.09 & 13.94 & 16.24 \\
\hline & & 1990s & 12.76 & 9.81 & 15.71 \\
\hline & & $2000 \mathrm{~s}$ & 3.09 & 2.25 & 3.93 \\
\hline & & $2010 s$ & 3.89 & 2.22 & 5.57 \\
\hline & \multirow[t]{4}{*}{$400+$} & $1980 \mathrm{~s}$ & 7.52 & 6.30 & 8.75 \\
\hline & & 1990s & 7.38 & 6.13 & 8.63 \\
\hline & & $2000 s$ & 7.45 & 5.97 & 8.93 \\
\hline & & $2010 s$ & 14.61 & 12.05 & 17.17 \\
\hline \multirow[t]{12}{*}{ Mean Individual Weight (g) } & \multirow[t]{4}{*}{$100-280$} & 1980s & 114.28 & 112.76 & 115.80 \\
\hline & & 1990s & 113.61 & 111.46 & 115.75 \\
\hline & & $2000 s$ & 111.20 & 108.60 & 113.80 \\
\hline & & $2010 \mathrm{~s}$ & 103.90 & 100.63 & 107.18 \\
\hline & \multirow[t]{4}{*}{$290-390$} & $1980 \mathrm{~s}$ & 408.05 & 405.07 & 411.03 \\
\hline & & 1990s & 411.01 & 407.02 & 414.99 \\
\hline & & $2000 s$ & 425.95 & 414.21 & 437.70 \\
\hline & & $2010 s$ & 463.37 & 453.82 & 472.92 \\
\hline & \multirow[t]{4}{*}{$400+$} & $1980 \mathrm{~s}$ & 682.80 & 674.98 & 690.63 \\
\hline & & 1990s & 710.92 & 701.58 & 720.26 \\
\hline & & $2000 s$ & 1004.89 & 987.98 & 1021.81 \\
\hline & & $2010 s$ & 1418.60 & 1405.55 & 1431.64 \\
\hline \multirow[t]{12}{*}{ Relative Weight } & \multirow[t]{4}{*}{$130-280$} & $1980 \mathrm{~s}$ & 58.84 & 58.46 & 59.22 \\
\hline & & 1990s & 58.71 & 58.37 & 59.05 \\
\hline & & $2000 \mathrm{~s}$ & 62.37 & 61.47 & 63.28 \\
\hline & & $2010 \mathrm{~s}$ & 68.38 & 67.48 & 69.28 \\
\hline & \multirow[t]{4}{*}{$290-390$} & $1980 \mathrm{~s}$ & 56.53 & 56.35 & 56.71 \\
\hline & & 1990s & 56.71 & 56.51 & 56.91 \\
\hline & & $2000 \mathrm{~s}$ & 61.56 & 60.77 & 62.36 \\
\hline & & $2010 \mathrm{~s}$ & 70.35 & 69.70 & 71.00 \\
\hline & \multirow[t]{4}{*}{$400+$} & $1980 \mathrm{~s}$ & 55.78 & 55.43 & 56.13 \\
\hline & & 1990s & 56.36 & 55.97 & 56.74 \\
\hline & & $2000 \mathrm{~s}$ & 63.50 & 63.00 & 64.00 \\
\hline & & $2010 \mathrm{~s}$ & 67.74 & 67.44 & 68.04 \\
\hline
\end{tabular}




\section{Appendix B}

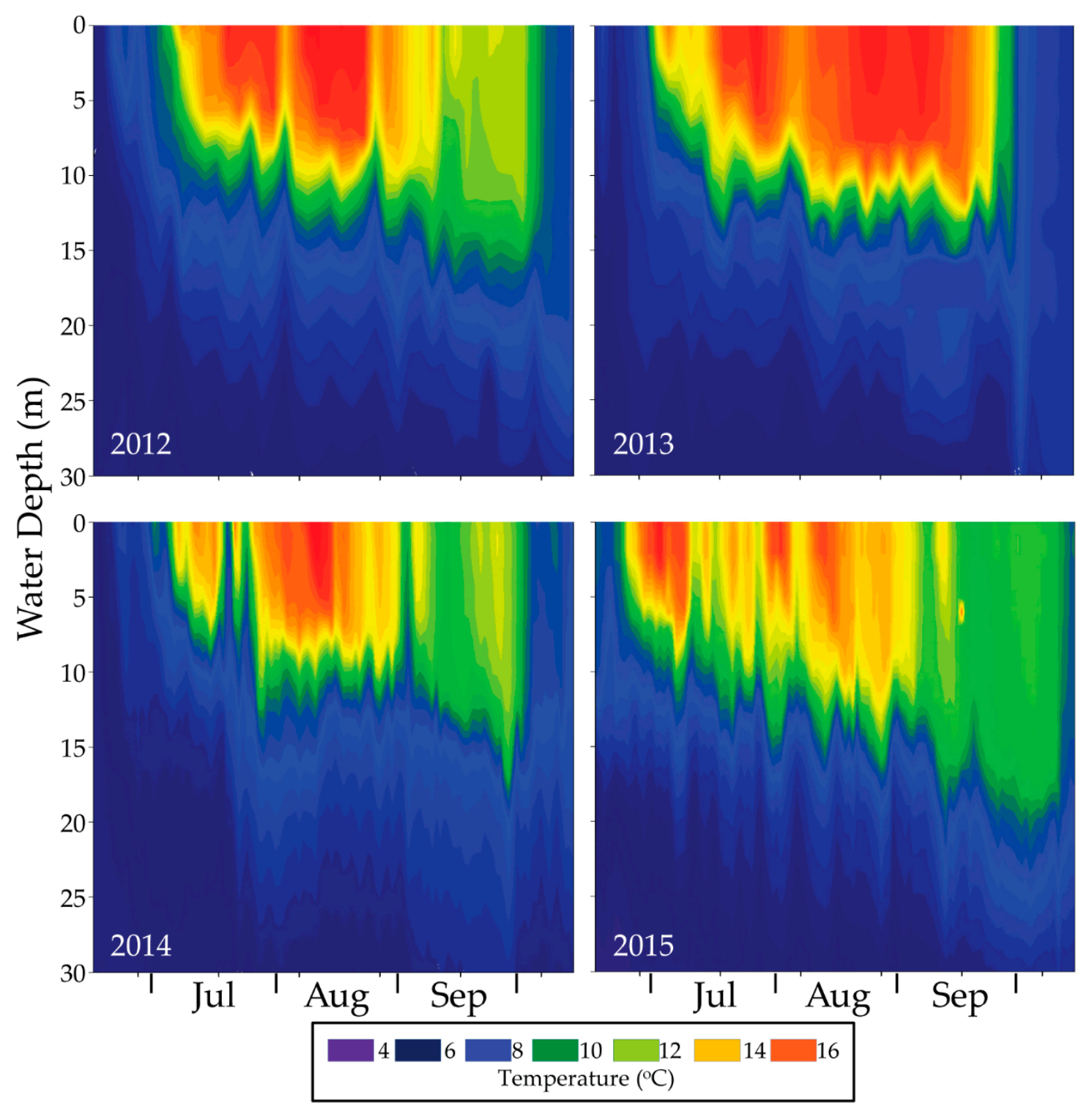

Figure A1. Depths of isotherms $\left({ }^{\circ} \mathrm{C}\right)$ measured using a multiparameter sonde (Hydrolab Surveyor) in the West Thumb of Yellowstone Lake during a portion of the ice-free period, 2012-2015. The thermal structure of Yellowstone Lake is typically unstable with a weak and variable thermocline in July, August, and September. During nine months of each year, there is no thermal cause for segregation of invasive lake trout and native cutthroat trout. Only the upper $30 \mathrm{~m}$ are shown for better resolution of surface water temperatures. 

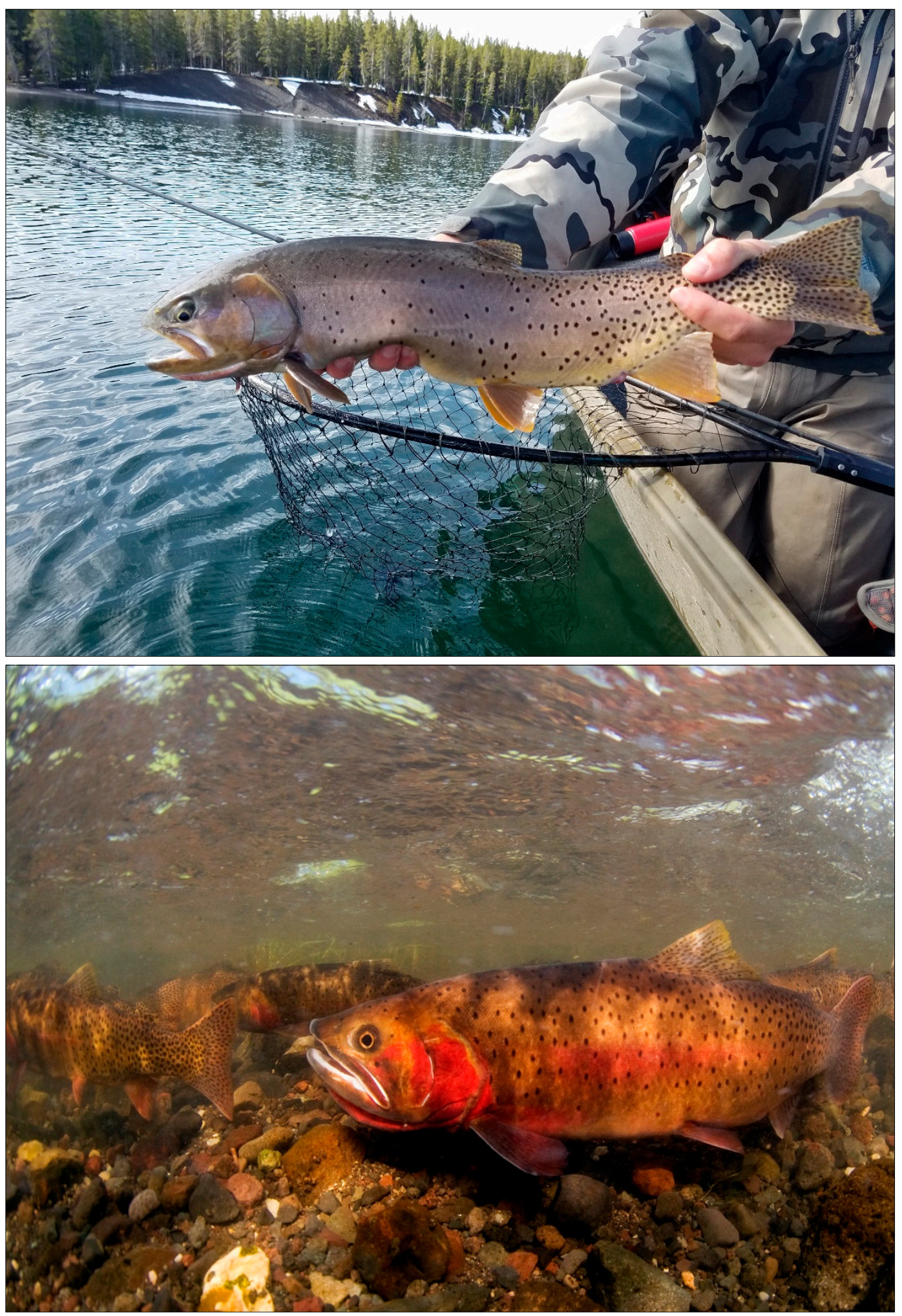

Figure A2. Native cutthroat trout accessed the upper Yellowstone River and Yellowstone Lake from the upper Snake River via natural connections across the Continental Divide following glacial recession about 14,000 years ago. Cutthroat trout then evolved as the sole salmonid and dominant fish within the lake and its connected river network. 

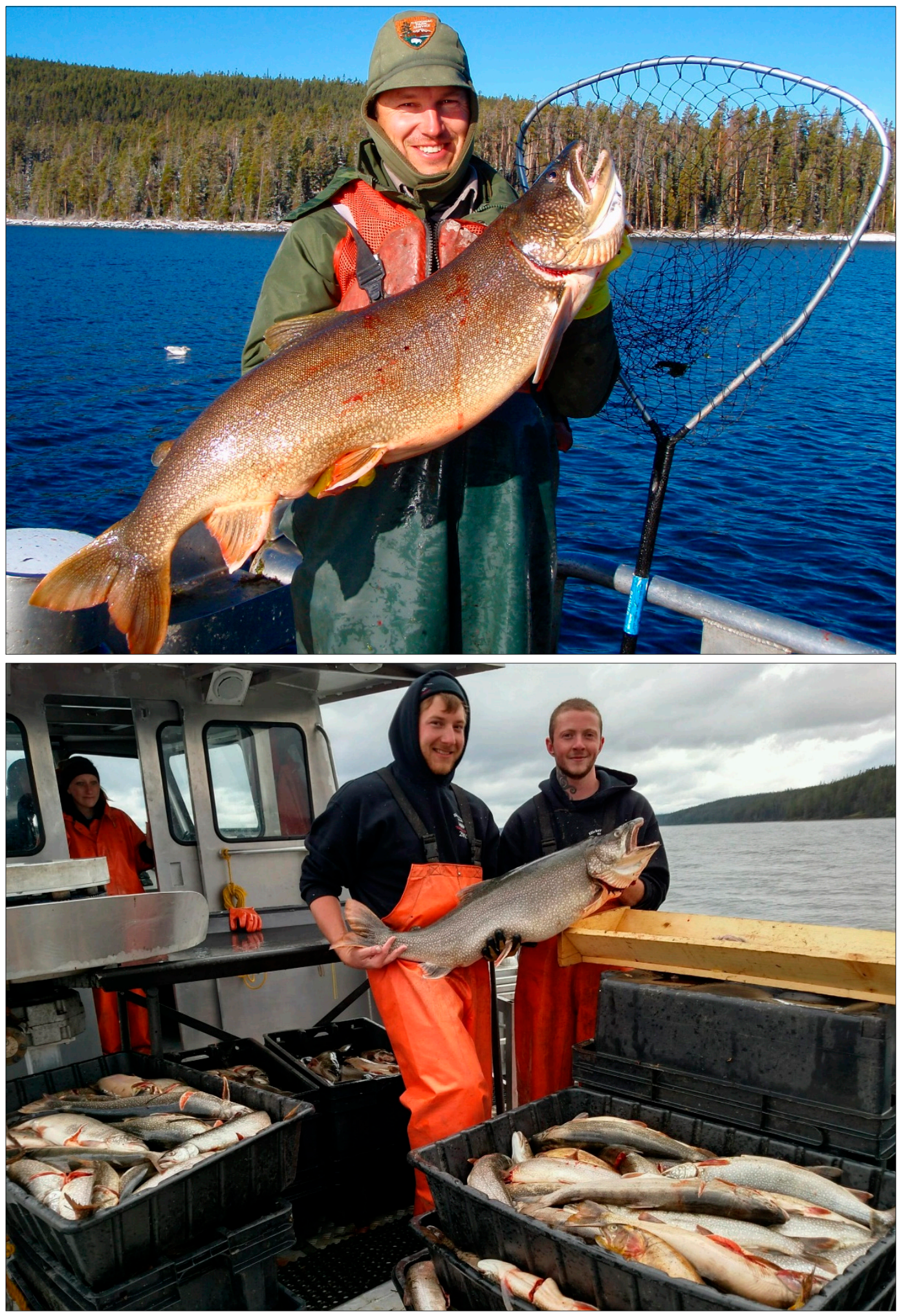

Figure A3. Invasive lake trout are a large-bodied, long-lived, and cold-adapted predatory species that became inadvertently introduced to Yellowstone Lake and were first discovered in 1994. They then became established as a new apex predatory trophic level within the lake. Because they are deep-water dwelling and do not use tributary streams, they are inaccessible to piscivorous avian and terrestrial wildlife and do not serve as an ecological substitute for native cutthroat trout. 


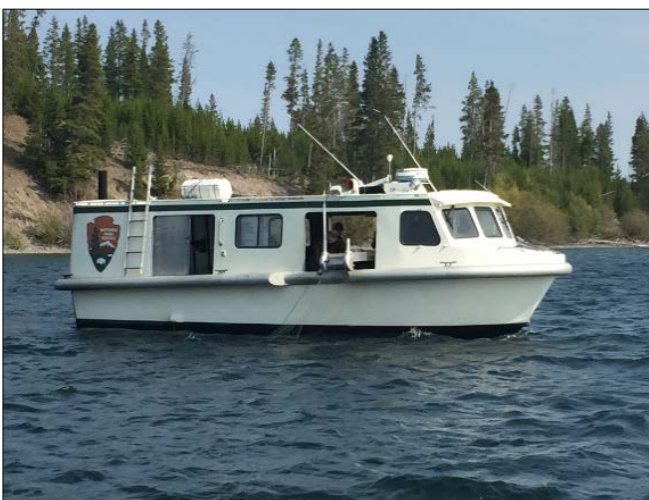

(A)

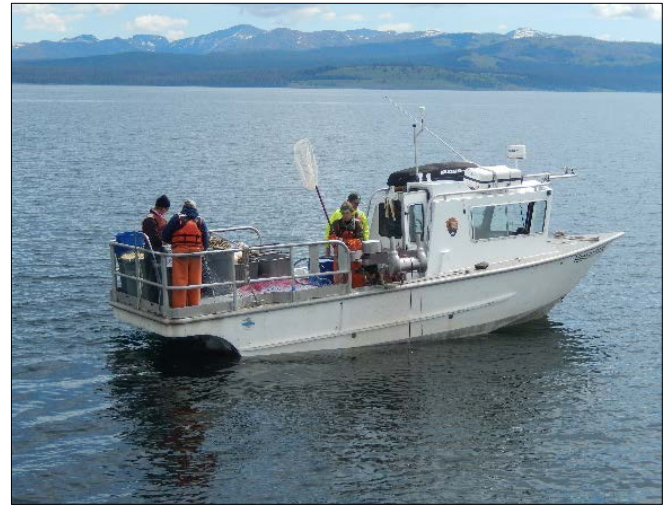

(B)

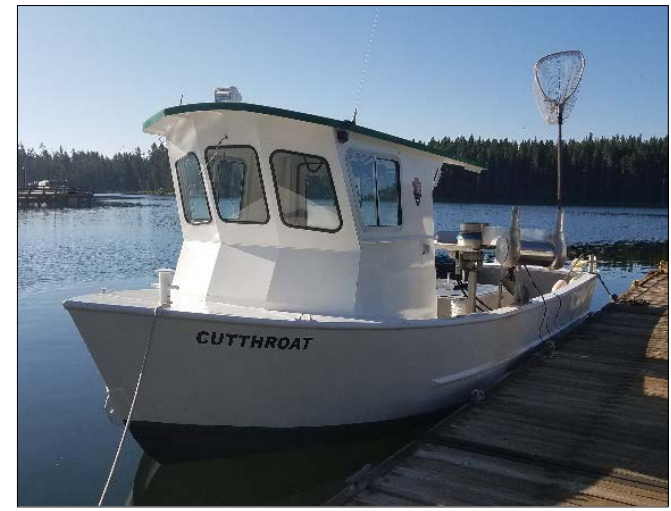

(C)

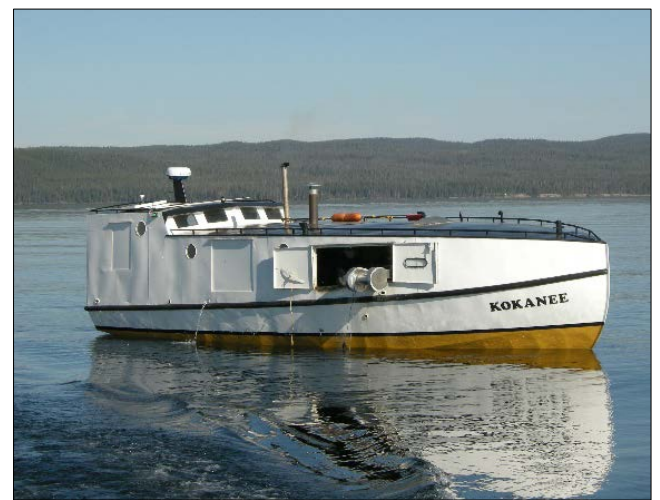

(D)

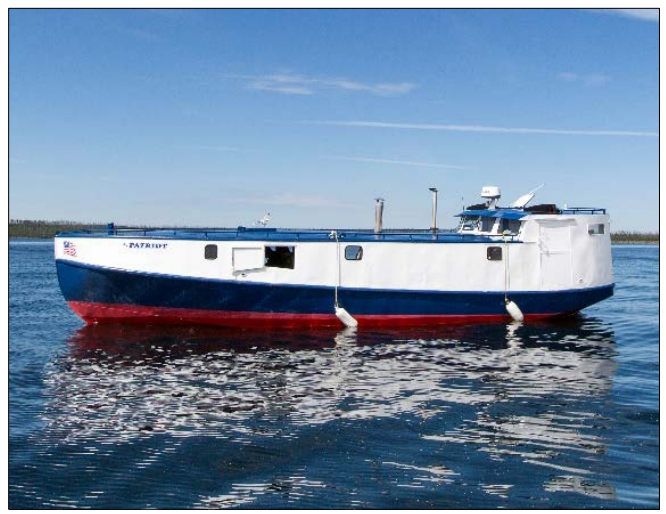

(E)

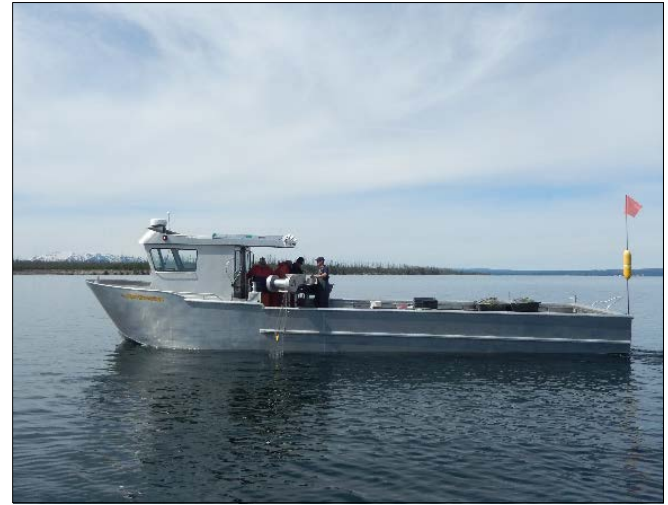

(F)

Figure A4. Lake trout gillnetting boats on Yellowstone Lake included (A-C) National Park Service Freedom, Hammerhead, and Cutthroat, and (D-F) Hickey Brothers Research, LLC. Kokanee, Patriot, and Northwester. 

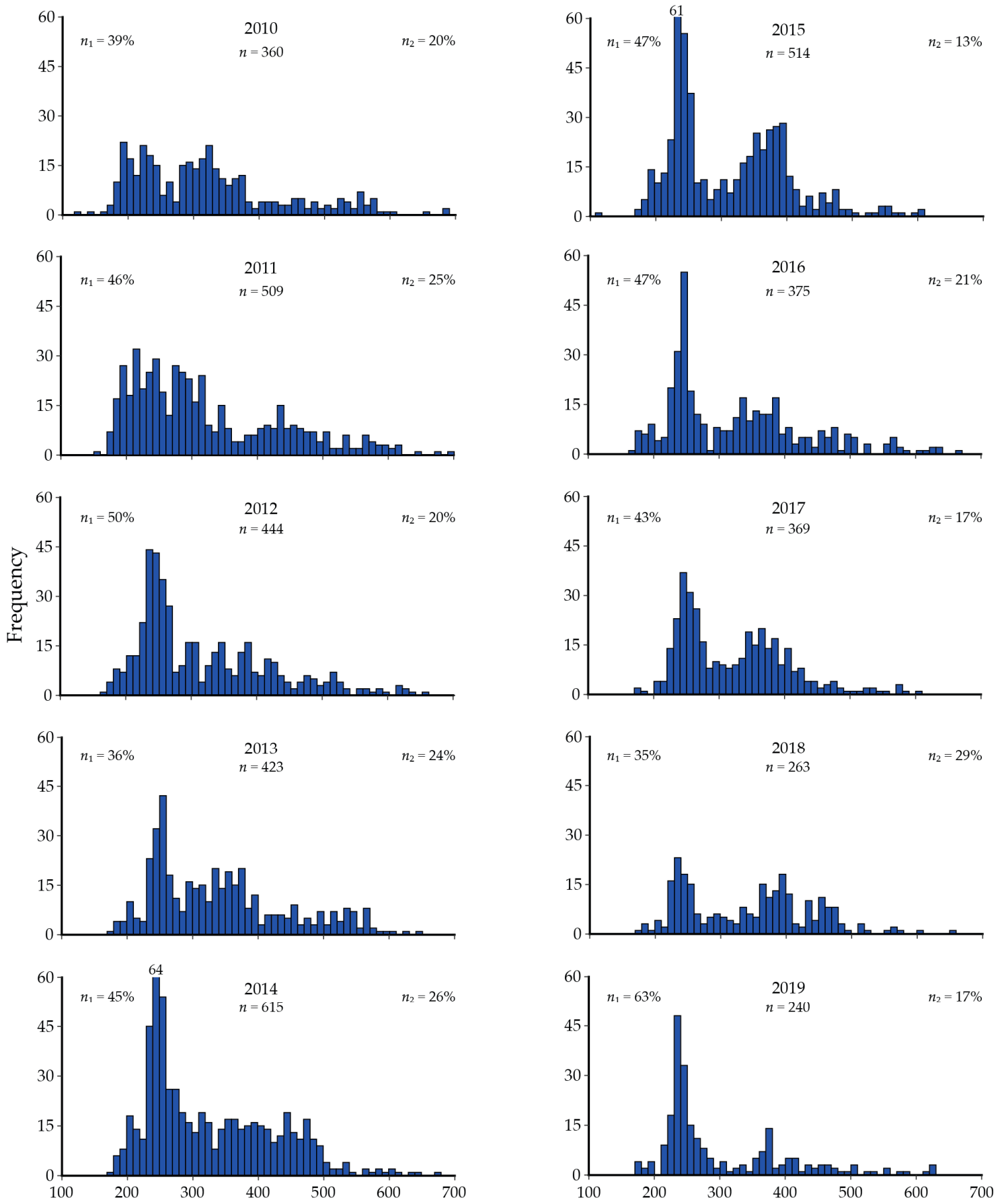

Length (mm)

Figure A5. Length-frequency distributions of lake trout sampled during annual long-term gillnetting assessments on Yellowstone Lake with total number sampled $(n)$, percentage $\leq 280 \mathrm{~mm}\left(n_{1}\right)$, and percentage $\geq 400 \mathrm{~mm}\left(n_{2}\right)$ each year, 2010-2019. 


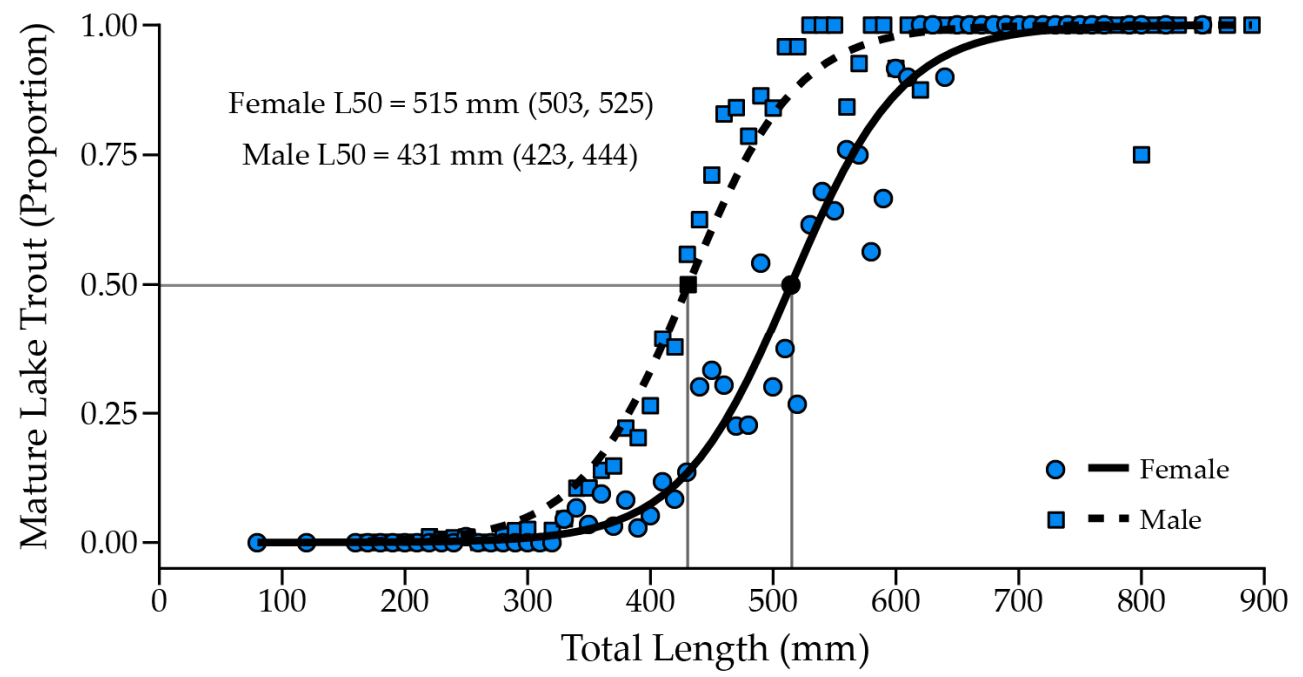

Figure A6. Proportions of mature female $(n=1766)$ and male $(n=2812)$ lake trout captured in Yellowstone Lake from 1996-2019 in 10-mm length bins with estimated length at which 50\% of fish were mature (L50; black symbols at inflection points) and 95\% confidence limits (in parentheses).

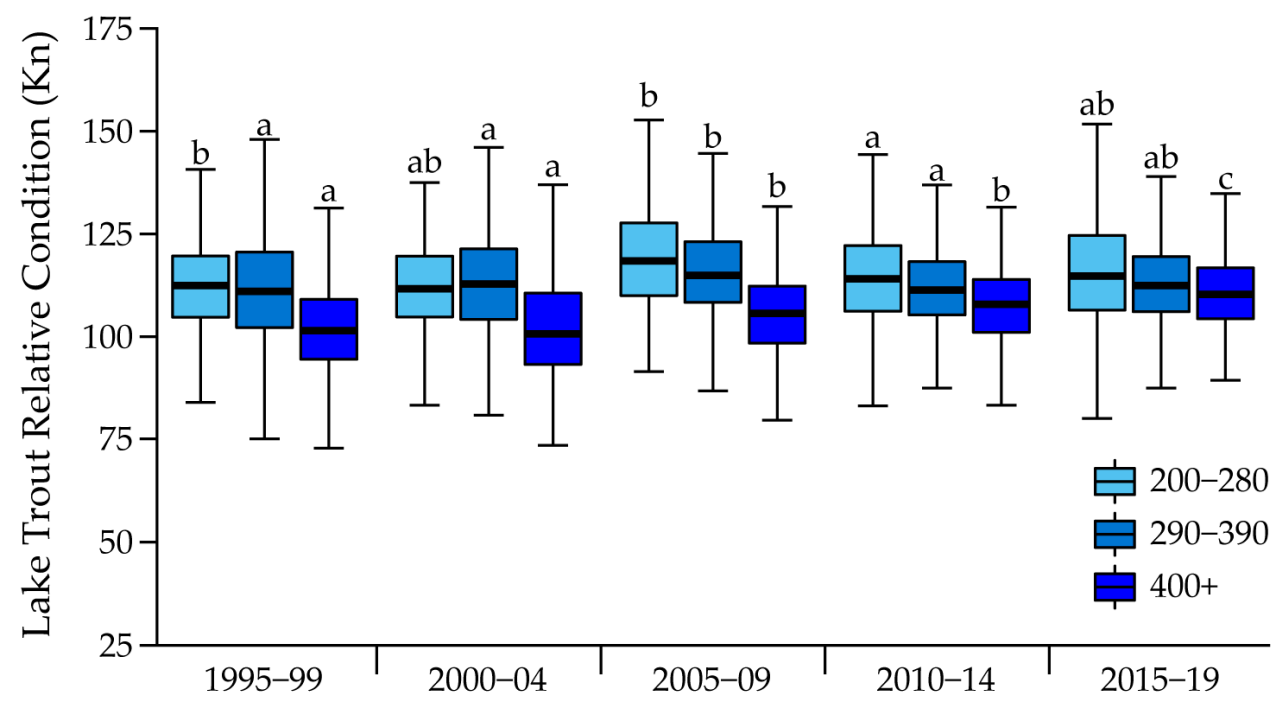

Figure A7. Relative condition $(\mathrm{Kn})$ for three length classes $(\mathrm{mm})$ of lake trout captured in Yellowstone Lake during periods of lake trout population growth (1995-1999, 2000-2004, and 2005-2009) and periods of population decline (2010-2014 and 2015-2019). Same letters (a-c) indicate no statistical difference in mean $\mathrm{Kn}$ between the five time periods for each length class. Over the past 25 years, the relative condition of large lake trout $(400+\mathrm{mm})$ has increased. Relative condition of smaller size classes did not appreciatively change. 

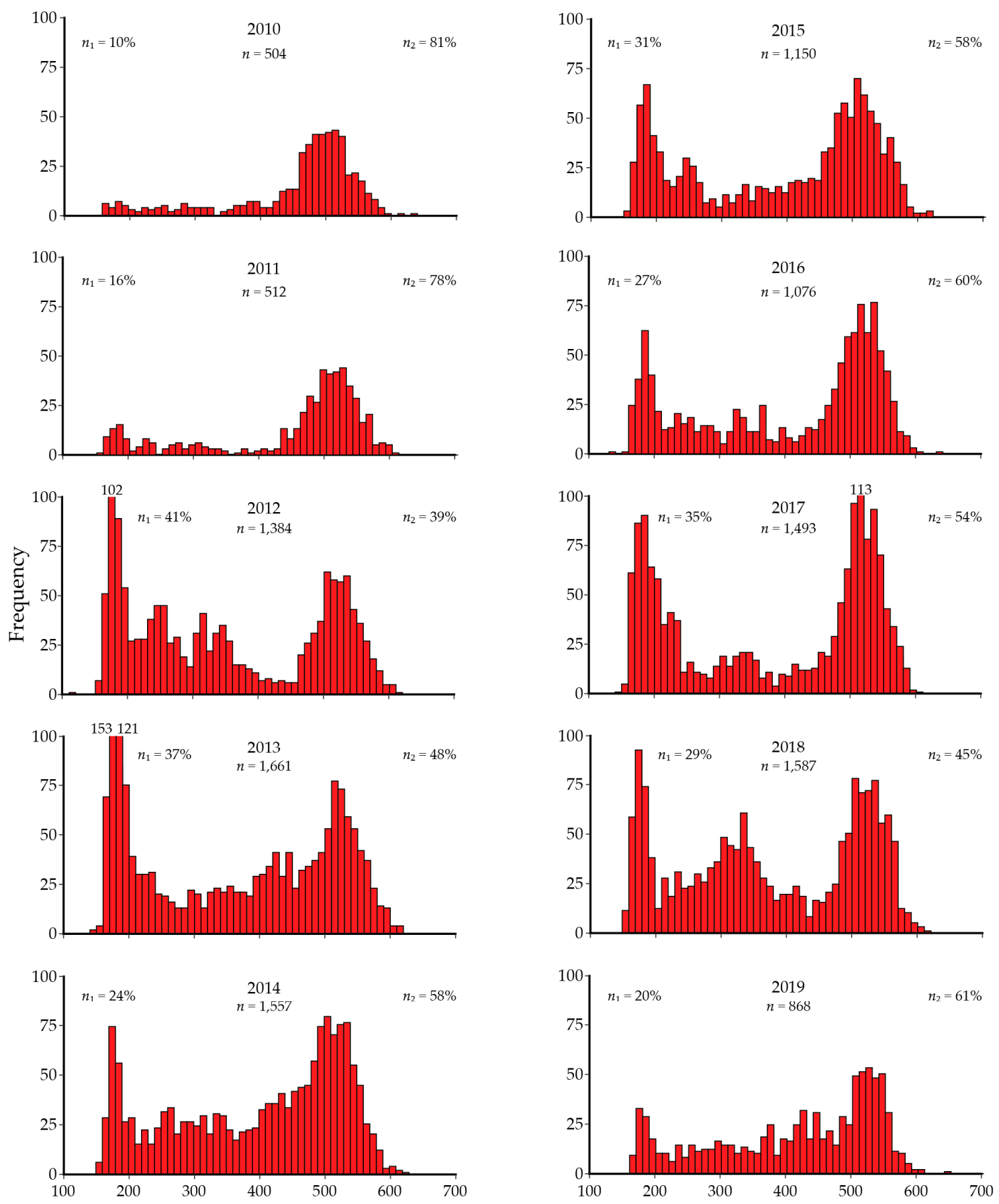

Length (mm)

Figure A8. Length-frequency distributions of cutthroat trout sampled during annual long-term gillnetting assessments on Yellowstone Lake with total number sampled $(n)$, percentage $\leq 280 \mathrm{~mm}\left(n_{1}\right)$, and percentage $\geq 400 \mathrm{~mm}\left(n_{2}\right)$ each year, 2010-2019. 


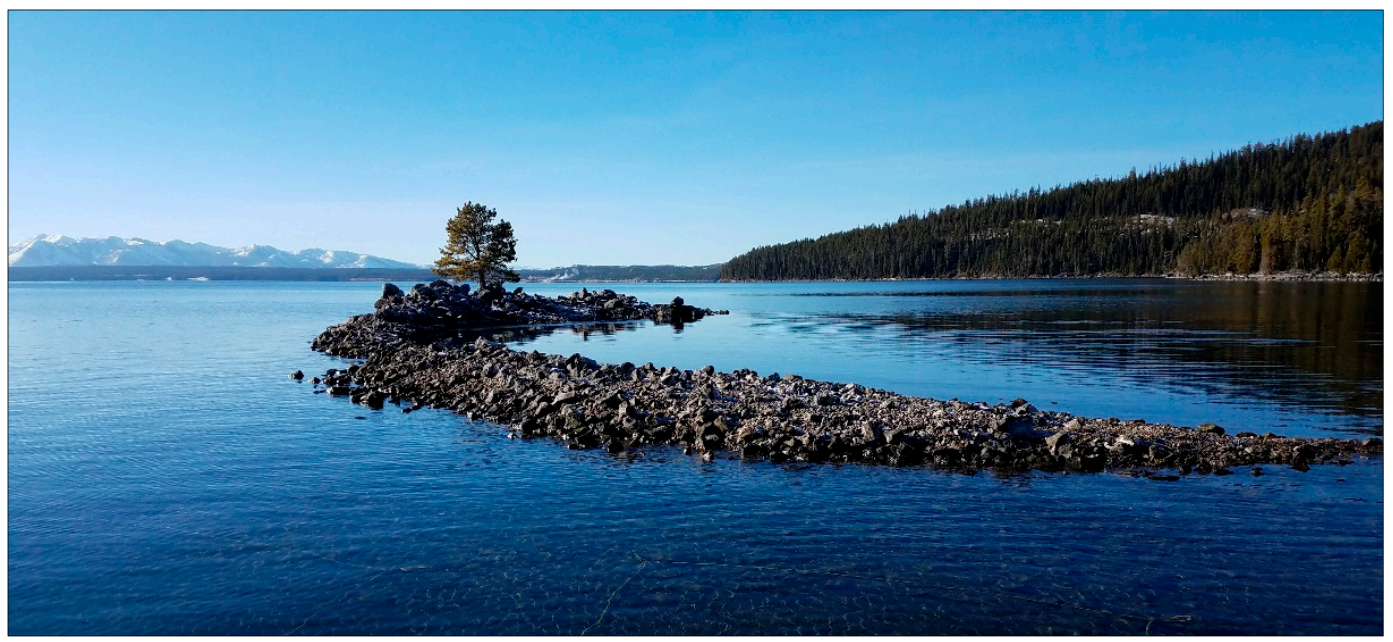

(A)

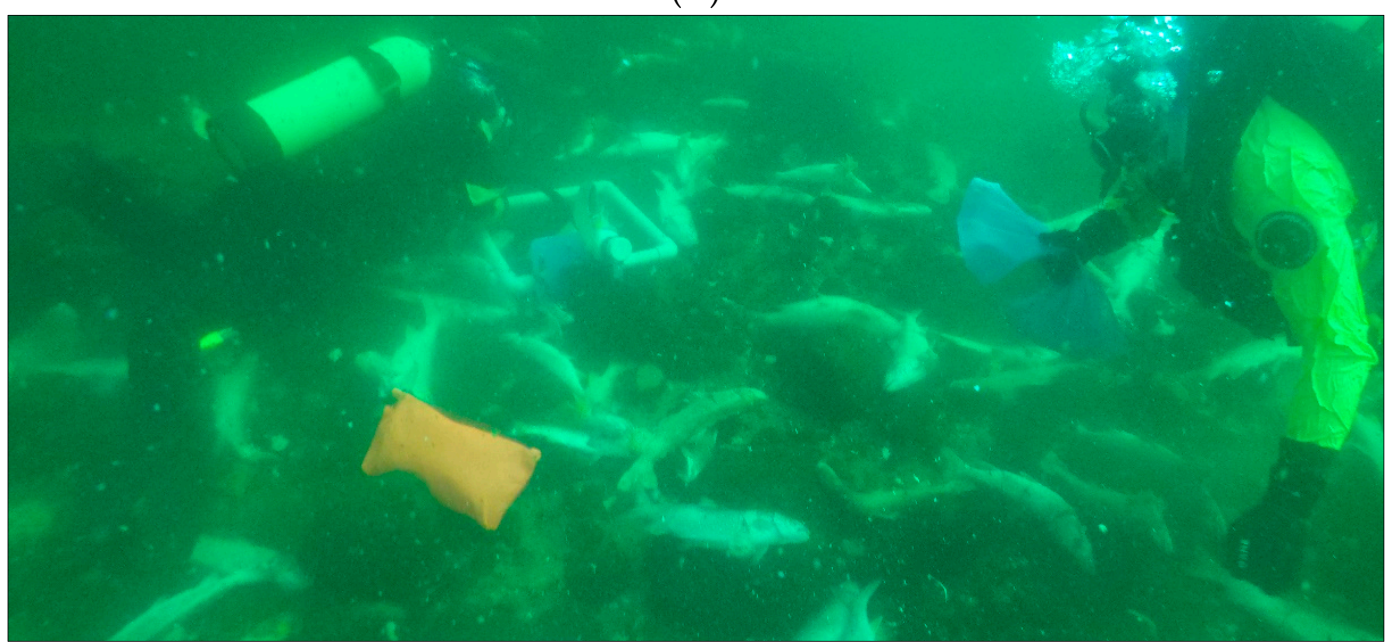

(B)

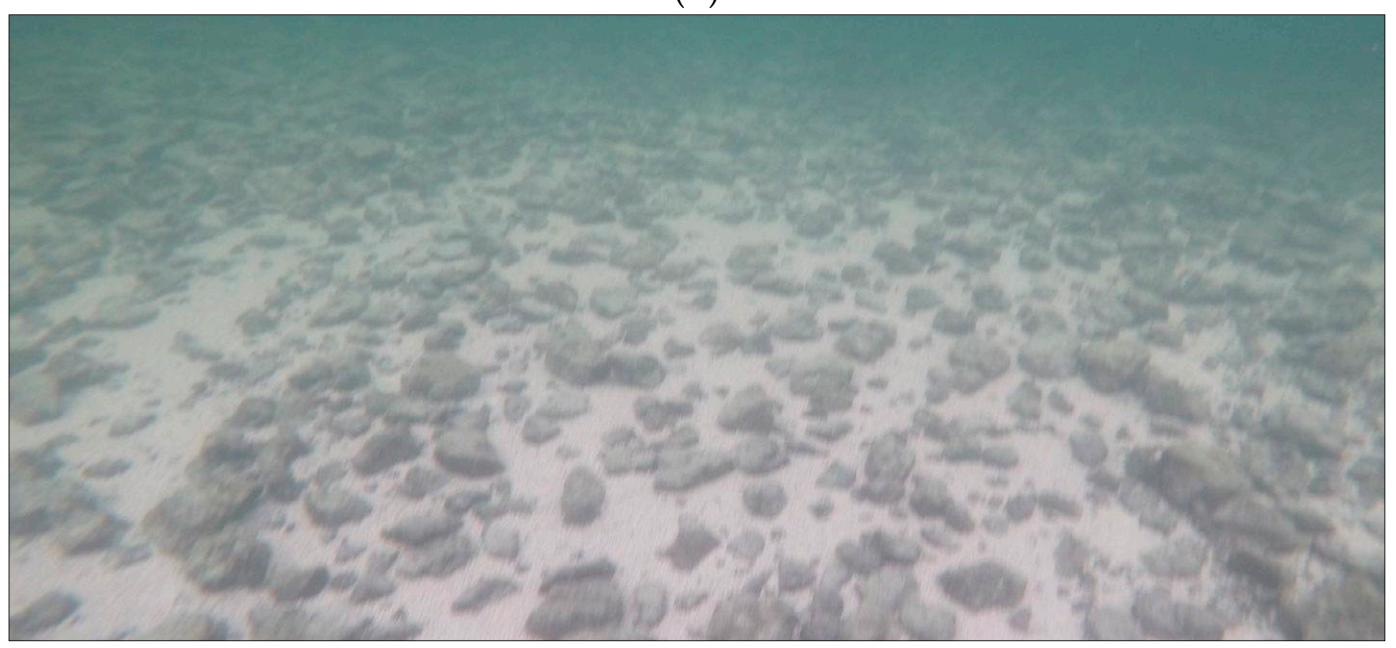

(C)

Figure A9. (A) The angular-rock substrate surrounding Carrington Island in the West Thumb is prime lake trout spawning habitat in Yellowstone Lake. (B) Scuba divers inspect the spatial coverage of lake trout carcasses, and (C) organic (soy and wheat gluten) pellets spread by helicopter to induce decomposition, reduce dissolved oxygen concentrations, and increase mortality of lake trout embryos. 


\section{References}

1. Gozlan, R.E.; Britton, J.R.; Cowx, I.; Copp, G.H. Current knowledge on non-native freshwater fish introductions. J. Fish Biol. 2010, 76, 751-786. [CrossRef]

2. Rahel, F.J.; Smith, M.A. Pathways of unauthorized fish introductions and types of management responses. Hydrobiologia 2018, 817, 41-56. [CrossRef]

3. Clarkson, R.W.; Marsh, P.C.; Stefferud, S.E.; Stefferud, J.A. Conflicts between native fish and nonnative sport fish management in the southwestern United States. Fisheries 2005, 30, 20-27. [CrossRef]

4. McMahon, T.E.; Bennett, D.H. Walleye and northern pike: Boost or bane to northwest fisheries? Fisheries 1996, 21, 6-13. [CrossRef]

5. Moyle, P.B.; Light, T. Biological invasions of fresh water: Empirical rules and assembly theory. Biol. Conserv. 1996, 78, 149-161. [CrossRef]

6. Vander Zanden, J.M.; Chandra, S.; Allen, B.C.; Reuter, J.E.; Goldman, C.R. Historical food web structure and restoration of native aquatic communities in the Lake Tahoe (California-Nevada) basin. Ecosystems 2003, 6, 274-288. [CrossRef]

7. Martinez, P.J.; Bigelow, P.E.; Deleray, M.A.; Fredenberg, W.A.; Hansen, B.S.; Horner, N.J.; Lehr, S.K.; Schneidervin, R.W.; Tolentino, S.A.; Viola, A.E. Western lake trout woes. Fisheries 2009, 34, 424-442. [CrossRef]

8. Olden, J.D.; Poff, N.L. Long-term trends of native and non-native fish faunas in the American Southwest. Anim. Biodivers. Conserv. 2005, 28, 75-89. Available online: https://www.raco.cat/index.php/ABC/article/ view/56742 (accessed on 10 June 2020).

9. Sanderson, B.L.; Barnas, K.A.; Rub, A.M.W. Nonindigenous species of the Pacific Northwest: An overlooked risk to endangered salmon? Bioscience 2009, 59, 245-256. [CrossRef]

10. Coggins, L.G.; Yard, M.D.; Pine, W.E. Nonnative fish control in the Colorado River in Grand Canyon, Arizona: An effective program or serendipitous timing? Trans. Am. Fish. Soc. 2011, 140, 456-470. [CrossRef]

11. Carpenter, S.R.; Kitchell, J.F.; Hodgson, J.R. Cascading trophic interactions and lake productivity. Bioscience 1985, 35, 634-639. [CrossRef]

12. Nico, L.G.; Fuller, P.L. Spatial and temporal patterns of nonindigenous fish introductions in the United States. Fisheries 1999, 24, 16-27. [CrossRef]

13. Rahel, F.J. Homogenization of fish faunas across the United States. Science 2000, 288, 854-856. [CrossRef]

14. Schade, C.B.; Bonar, S.A. Distribution and abundance of nonnative fishes in streams of the western United States. N. Am. J. Fish. Manag. 2005, 25, 1386-1394. [CrossRef]

15. Britton, J.R.; Gozlan, R.E.; Copp, G.H. Managing non-native fish in the environment. Fish Fish. 2011, 12, 256-274. [CrossRef]

16. Rytwinski, T.; Taylor, J.J.; Donaldson, L.A.; Britton, J.R.; Browne, D.R.; Gresswell, R.E.; Lintermans, M.; Prior, K.A.; Pellatt, M.G.; Vis, C.; et al. The effectiveness of non-native fish removal techniques in freshwater ecosystems: A systematic review. Environ. Rev. 2018, 27, 71-94. [CrossRef]

17. Mueller, G.A. Predatory fish removal and native fish recovery in the Colorado River mainstem. Fisheries 2005, 30, 10-19. [CrossRef]

18. Fredenberg, C.R.; Muhlfeld, C.C.; Guy, C.S.; D'Angelo, V.S.; Downs, C.C.; Syslo, J.M. Suppression of invasive lake trout in an isolated backcountry lake in Glacier National Park. Fish. Manag. Ecol. 2017, 24, $33-48$. [CrossRef]

19. Dux, A.M.; Hansen, M.J.; Corsi, M.P.; Wahl, N.C.; Fredericks, J.P.; Corsi, C.E.; Schill, D.J.; Horner, N.J. Effectiveness of lake trout (Salvelinus namaycush) suppression in Lake Pend Oreille, Idaho: 2006-2016. Hydrobiologia 2019, 840, 319-333. [CrossRef]

20. Dux, A.M.; Guy, C.S.; Fredenberg, W.A. Spatiotemporal distribution and population characteristics of a nonnative lake trout population, with implications for suppression. N. Am. J. Fish. Manag. 2011, 31, 187-196. [CrossRef]

21. Klein, Z.B.; Quist, M.C.; Rhea, D.T.; Senecal, A.C. Population characteristics and the suppression of nonnative burbot. N. Am. J. Fish. Manag. 2016, 36, 1006-1017. [CrossRef]

22. Kaus, D.J. Feasibility of Walleye Population Suppression in Buffalo Bill Reservoir, Wyoming. Master's Thesis, Montana State University, Bozeman, MT, USA, 2019. 
23. Quist, M.C.; Hubert, W.A. Bioinvasive species and the preservation of cutthroat trout in the western United States: Ecological, social, and economic issues. Environ. Sci. Policy 2004, 7, 303-313. [CrossRef]

24. Shollenberger, H.; Dressler, E.; Mallinson, D.J. Invasive snakehead and introduced sport fish illustrate an environmental health paradox of invasive species and angler demand. Case Stud. Environ. 2019, 3, 1-10. [CrossRef]

25. Syslo, J.M.; Guy, C.S.; Cox, B.S. Comparison of harvest scenarios for the cost-effective suppression of lake trout in Swan Lake, Montana. N. Am. J. Fish. Manag. 2013, 33, 1079-1090. [CrossRef]

26. Hansen, M.J.; Guy, C.S.; Budy, P.; McMahon, T.E. Trout as native and nonnative species: A management paradox. In Trouts and Char of the World; Kershner, J.L., Williams, J.E., Gresswell, R.E., Lobón-Cerviá, J., Eds.; American Fisheries Society: Bethesda, MD, USA, 2019; pp. 645-684.

27. Walters, C.J.; Holling, C.S. Large-scale management experiments and learning by doing. Ecology 1990, 71, 2060-2068. [CrossRef]

28. McCarthy, M.A.; Possingham, H.P. Active adaptive management for conservation. Conserv. Biol. 2007, 21, 956-963. [CrossRef] [PubMed]

29. Holling, C.S. Adaptive Environmental Assessment and Management; Wiley: London, UK, 1978.

30. Walters, C.J. Is adaptive management helping to solve fisheries problems? AMBIO J. Hum. Environ. 2007, 36, 304-307. [CrossRef]

31. Walters, C.J. Adaptive Management of Renewable Resources; Macmillan: New York, NY, USA, 1986.

32. Runge, M.C. An introduction to adaptive management for threatened and endangered species. J. Fish Wildl. Manag. 2011, 2, 220-233. [CrossRef]

33. Estes, J.A.; Terborgh, J.; Brashares, J.S.; Power, M.E.; Berger, J.; Bond, W.J.; Carpenter, S.R.; Essington, T.E.; Holt, R.D.; Jackson, J.B.C.; et al. Trophic downgrading of planet Earth. Science 2011, 333, 301. [CrossRef]

34. Thom, R.; St Clair, T.; Burns, R.; Anderson, M. Adaptive management of large aquatic ecosystem recovery programs in the United States. J. Environ. Manag. 2016, 183, 424-430. [CrossRef]

35. Zavaleta, E.S.; Hobbs, R.J.; Mooney, H.A. Viewing invasive species removal in a whole-ecosystem context. Trends Ecol. Evol. 2001, 16, 454-459. [CrossRef]

36. Prior, K.M.; Adams, D.C.; Klepzig, K.D.; Hulcr, J. When does invasive species removal lead to ecological recovery? Implications for management success. Biol. Invasions 2018, 20, 267-283. [CrossRef]

37. Parker, I.M.; Simberloff, D.; Lonsdale, W.M.; Goodell, K.; Wonham, M.; Kareiva, P.M.; Williamson, M.H.; Von Holle, B.; Moyle, P.B.; Byers, J.E.; et al. Impact: Toward a framework for understanding the ecological effects of invaders. Biol. Invasions 1999, 1, 3-19. [CrossRef]

38. Kaplinski, M.A. Geomorphology and Geology of Yellowstone Lake, Yellowstone National Park, Wyoming. Master's Thesis, Northern Arizona University, Flagstaff, AZ, USA, 1991.

39. Remsen, C.C.; Maki, J.S.; Klump, J.V.; Aguilar, C.; Anderson, P.D.; Buchholz, L.; Cuhel, R.L.; Lovalvo, D.; Paddock, R.W.; Waples, J.; et al. Sublacustrine geothermal activity in Yellowstone Lake: Studies past and present. In Yellowstone Lake: Hotbed of Chaos or Reservoir of Resilience, Proceedings of the 6th Biennial Scientific Conference on the Greater Yellowstone Ecosystem; Anderson, R.J., Harmon, D., Eds.; Yellowstone Center for Resources and The George Wright Society: Yellowstone National Park, WY, USA, 2002.

40. Gresswell, R.E.; Varley, J.D. Effects of a century of human influence on the cutthroat trout of Yellowstone Lake. Am. Fish. Soc. Symp. 1988, 4, 45-52.

41. Koel, T.M.; Tronstad, L.M.; Arnold, J.L.; Gunther, K.A.; Smith, D.W.; Syslo, J.M.; White, P.J. Predatory fish invasion induces within and across ecosystem effects in Yellowstone National Park. Sci. Adv. 2019, 5, eaav1139. [CrossRef]

42. Koel, T.M.; Arnold, J.L.; Bigelow, P.E.; Detjens, C.R.; Doepke, P.D.; Ertel, B.D.; Ruhl, M.E. Native Fish Conservation Program, Yellowstone Fisheries and Aquatic Sciences 2012-2014; YCR-2015-01; National Park Service, Yellowstone Center for Resources: Yellowstone National Park, WY, USA, 2015. Available online: https: //www.nps.gov/yell/learn/nature/upload/2012-2014_yellowstone_fisheries.pdf (accessed on 10 June 2020).

43. Jordan, D.S. A reconnaissance of streams and lakes of Yellowstone National Park, Wyoming in the interest of the U.S. Fish Commission. Bull. U.S. Fish Comm. 1891, 9, 41-63.

44. Behnke, R.J. Trout and Salmon of North America; Free Press: New York, NY, USA, 2002.

45. Licciardi, J.M.; Pierce, K.L. History and dynamics of the Greater Yellowstone Glacial System during the last two glaciations. Quat. Sci. Rev. 2018, 200,1-33. [CrossRef] 
46. Ertel, B.D.; McMahon, T.E.; Koel, T.M.; Gresswell, R.E.; Burckhardt, J.C. Life history migrations of adult Yellowstone cutthroat trout in the upper Yellowstone River. N. Am. J. Fish. Manag. 2017, 37, 743-755. [CrossRef]

47. Gresswell, R.E.; Liss, W.J.; Larson, G.L. Life-history organization of Yellowstone cutthroat trout (Oncorhynchus clarkii bouvieri) in Yellowstone Lake. Can. J. Fish. Aquat. Sci. 1994, 51, 298-309. [CrossRef]

48. Kaeding, L.R.; Boltz, G.D. Spatial and temporal relations between fluvial and allacustrine Yellowstone cutthroat trout, Oncorhynchus clarkii bouvieri, spawning in the Yellowstone River, outlet stream of Yellowstone Lake. Environ. Biol. Fishes 2001, 61, 395-406. [CrossRef]

49. Tronstad, L.M.; Hall, R.O., Jr.; Koel, T.M. Introduced lake trout alter nitrogen cycling beyond Yellowstone Lake. Ecosphere 2015, 6, 224. [CrossRef]

50. Felicetti, L.A.; Schwartz, C.C.; Rye, R.O.; Gunther, K.A.; Crock, J.G.; Haroldson, M.A.; Waits, L.; Robbins, C.T. Use of naturally occurring mercury to determine the importance of cutthroat trout to Yellowstone grizzly bears. Can. J. Zool. 2004, 82, 493-501. [CrossRef]

51. Koel, T.M.; Bigelow, P.E.; Doepke, P.D.; Ertel, B.D.; Mahony, D.L. Nonnative lake trout result in Yellowstone cutthroat trout decline and impacts to bears and anglers. Fisheries 2005, 30, 10-19. [CrossRef]

52. Baril, L.M.; Smith, D.W.; Drummer, T.; Koel, T.M. Implications of cutthroat trout declines for breeding ospreys and bald eagles at Yellowstone Lake. J. Raptor Res. 2013, 47, 234-245. [CrossRef]

53. Bergum, D.J.; Gunther, K.A.; Baril, L.M. Birds and mammals that consume Yellowstone cutthroat trout in Yellowstone Lake and its tributaries. Yellowstone Sci. 2017, 25, 86-89. Available online: https://www. researchgate.net/publication/318281009 (accessed on 10 June 2020).

54. Benson, N.G. Limnology of Yellowstone Lake in Relation to the Cutthroat Trout; Research Report 56; U.S. Department of the Interior, Fish and Wildlife Service, Bureau of Sport Fisheries and Wildlife: Washington, DC, USA, 1961. Available online: http://doi.org/10.5281/zenodo.3890470 (accessed on 10 June 2020).

55. Crait, J.R.; Ben-David, M. River otters in Yellowstone Lake depend on a declining cutthroat trout population. J. Mammal. 2006, 87, 485-494. [CrossRef]

56. Swenson, J.E. Prey and foraging behavior of ospreys on Yellowstone Lake, Wyoming. J. Wildl. Manag. 1978, 42, 87-90. [CrossRef]

57. Diem, K.L.; Pugesek, B.H. American white pelicans at the Molly Islands, in Yellowstone National Park: Twenty-two years of boom-and-bust breeding, 1966-1987. Colonial Waterbirds 1994, 17, 130-145. [CrossRef]

58. Walker, L.E.; Smith, D.W.; Albrechtsen, M.B.; Cassidy, B.J.; Shields, E.M.; Duffy, K. Yellowstone Bird Project: Annual Report 2018; YCR-2019-01; National Park Service, Yellowstone Center for Resources: Yellowstone National Park, WY, USA, 2019. Available online: https://www.nps.gov/yell/learn/nature/upload/2018-BirdReport_web.pdf (accessed on 10 June 2020).

59. Koel, T.M.; Thomas, N.A.; Guy, C.S.; Doepke, P.D.; MacDonald, D.J.; Poole, A.S.; Sealey, W.M.; Zale, A.V. Organic pellet decomposition induces mortality of lake trout embryos in Yellowstone Lake. Trans. Am. Fish. Soc. 2020, 149, 57-70. [CrossRef]

60. Williams, J.R. Quantifying the Spatial Structure of Invasive Lake Trout in Yellowstone Lake to Improve Suppression Efficacy. Master's Thesis, Montana State University, Bozeman, MT, USA, 2019.

61. Flavelle, L.S.; Ridgway, M.S.; Middel, T.A.; McKinley, R.S. Integration of acoustic telemetry and GIS to identify potential spawning areas for lake trout (Salvelinus namaycush). Hydrobiologia 2002, 483, 137-146. [CrossRef]

62. Bigelow, P.E. Predicting Areas of Lake Trout Spawning Habitat within Yellowstone Lake, Wyoming. Ph.D. Thesis, University of Wyoming, Laramie, WY, USA, 2009.

63. Gresswell, R.E.; Liss, W.J. Values associated with management of Yellowstone cutthroat trout in Yellowstone National Park. Conserv. Biol. 1995, 9, 159-165. [CrossRef]

64. Byorth, J. Trout shangri-La: Remaking the fishing in Yellowstone National Park, Montana. Mag. West. Hist. 2002, 52, 38-47.

65. Varley, J.D.; Schullery, P.D. Yellowstone Fishes: Ecology, History, and Angling in the Park; Stackpole Books: Mechanicsburg, PA, USA, 1998.

66. Biesinger, K.E. Studies on the Relationship of the Redside Shiner (Richardsonius balteatus) and the Longnose Sucker (Catostomus catostomus) to the Cutthroat Trout (Salmo clarki) Population in Yellowstone Lake. Master's Thesis, Utah State University, Logan, UT, USA, 1961. 
67. Davenport, M. Piscivorous Avifauna on Yellowstone Lake, Yellowstone National Park; U.S. Department of the Interior, National Park Service: Yellowstone National Park, WY, USA, 1974. [CrossRef]

68. Brown, C.J.D.; Graham, R.J. Observations on the longnose sucker in Yellowstone Lake. Trans. Am. Fish. Soc. 1954, 83, 38-46. [CrossRef]

69. Furey, K.M.; Glassic, H.C.; Guy, C.S.; Koel, T.M.; Arnold, J.L.; Doepke, P.D.; Bigelow, P.E. Diets of longnose sucker in Yellowstone Lake, Yellowstone National Park, U.S.A. J. Freshw. Ecol. 2020. (under review).

70. Madsen, D.H. Protection of native fishes in the national parks. Trans. Am. Fish. Soc. 1937, 66, $395-397$. [CrossRef]

71. Leopold, A.S.; Cain, S.A.; Cottam, C.M.; Gabrielson, I.N.; Kimba, T.L. Wildlife Management in the National Parks; Report to the Secretary of the Interior; Advisory Board on Wildlife Management: Washington, DC, USA, 1963; Available online: http://npshistory.com/publications/leopold_report.pdf (accessed on 10 June 2020).

72. Jones, R.D.; Gresswell, R.E.; Jennings, D.E.; Rubrecht, S.M.; Varley, J.D. Fishery and Aquatic Management Program in Yellowstone National Park; Tech. Rep. 1979; U.S. Fish and Wildlife Service: Yellowstone National Park, WY, USA, 1980. [CrossRef]

73. Kaeding, L.R.; Boltz, G.D.; Carty, D.G. Lake trout discovered in Yellowstone Lake threaten native cutthroat trout. Fisheries 1996, 21, 16-20. [CrossRef]

74. Koel, T.M.; Detjens, C.R.; Zale, A.V. Two Ocean Pass: An alternative hypothesis for invasion of Yellowstone Lake by lake trout, and implications for future invasions. Water 2020, 12, 1629. [CrossRef]

75. Scott, W.B.; Crossman, E.J. Freshwater Fishes of Canada; Bulletin 184; Fisheries Research Board of Canada: Ottawa, ON, Canada, 1973.

76. Ryder, R.A.; Kerr, S.R.; Taylor, W.W.; Larkin, P.A. Community consequences of fish stock diversity. Can. J. Fish. Aquat. Sci. 1981, 38, 1856-1866. [CrossRef]

77. Healey, M.C. The dynamics of exploited lake trout populations and implications for management. J. Wildl. Manag. 1978, 42, 307-328. [CrossRef]

78. Muir, A.M.; Blackie, C.T.; Marsden, J.E.; Krueger, C.C. Lake charr Salvelinus namaycush spawning behaviour: New field observations and a review of current knowledge. Rev. Fish Biol. Fish. 2012, 22, 575-593. [CrossRef]

79. Ruzycki, J.R.; Beauchamp, D.A.; Yule, D.L. Effects of introduced lake trout on native cutthroat trout in Yellowstone Lake. Ecol. Appl. 2003, 13, 23-37. [CrossRef]

80. Syslo, J.M.; Guy, C.S.; Bigelow, P.E.; Doepke, P.D.; Ertel, B.D.; Koel, T.M. Response of non-native lake trout (Salvelinus namaycush) to 15 years of harvest in Yellowstone Lake, Yellowstone National Park. Can. J. Fish. Aquat. Sci. 2011, 68, 2132-2145. [CrossRef]

81. Syslo, J.M.; Brenden, T.O.; Guy, C.S.; Koel, T.M.; Bigelow, P.E.; Doepke, P.D.; Arnold, J.L.; Ertel, B.D. Could ecological release buffer suppression efforts for non-native lake trout (Salvelinus namaycush) in Yellowstone Lake, Yellowstone National Park? Can. J. Fish. Aquat. Sci. 2020, 77, 1010-1025. [CrossRef]

82. Varley, J.D.; Schullery, P. The Yellowstone Lake Crisis: Confronting a Lake Trout Invasion; A Report to the Director of the National Park Service; Yellowstone Center for Resources, National Park Service: Yellowstone National Park, WY, USA, 1995. Available online: https://www.nps.gov/parkhistory/online_books/yell/trout_invasion.pdf (accessed on 10 June 2020).

83. McIntyre, J.D. Review and assessment of possibilities for protecting the cutthroat trout of Yellowstone Lake from introduced lake trout. In The Yellowstone Lake Crisis: Confronting a Lake Trout Invasion. A Report to the Director of the National Park Service; Varley, J.D., Schullery, P., Eds.; Yellowstone Center for Resources, National Park Service: Yellowstone National Park, WY, USA, 1995; pp. 28-33.

84. Ruzycki, J.R. Impact of Lake Trout Introductions on Cutthroat Trout of Selected Western Lakes of the Continental United States. Ph.D. Thesis, Utah State University, Logan, UT, USA, 2004.

85. Koel, T.M.; Arnold, J.L.; Bigelow, P.E.; Doepke, P.D.; Ertel, B.D.; Ruhl, M.E. Yellowstone Fisheries and Aquatic Sciences: Annual Report, 2008; YCR-2010-03; National Park Service, Yellowstone Center for Resources: Yellowstone National Park, WY, USA, 2010. Available online: https:/www.nps.gov/yell/planyourvisit/ upload/2008_fisheries_ar_final.pdf (accessed on 10 June 2020).

86. Tronstad, L.M.; Hall, R.O.; Koel, T.M.; Gerow, K.G. Introduced lake trout produced a four-level trophic cascade in Yellowstone Lake. Trans. Am. Fish. Soc. 2010, 139, 1536-1550. [CrossRef]

87. Middleton, A.D.; Morrison, T.A.; Fortin, J.K.; Robbins, C.T.; Proffitt, K.M.; White, P.J.; McWhirter, D.E.; Koel, T.M.; Brimeyer, D.G.; Fairbanks, W.S.; et al. Grizzly bear predation links the loss of native trout to the demography of migratory elk in Yellowstone. Proc. R. Soc. B Biol. Sci. 2013, 280, 20130870. [CrossRef] 
88. Gresswell, R.E. Scientific Review Panel Evaluation of the National Park Service Lake Trout Suppression Program in Yellowstone Lake, 25-29 August; Final Report, YCR-2009-05; USGS Northern Rocky Mountain Science Center: Bozeman, MT, USA, 2009. Available online: https://www.nps.gov/yell/planyourvisit/upload/gresswell_final_ updated_1_2010.pdf (accessed on 10 June 2020).

89. Hansen, M.J.; Horner, N.J.; Liter, M.; Peterson, M.P.; Maiolie, M.A. Dynamics of an increasing lake trout population in Lake Pend Oreille, Idaho. N. Am. J. Fish. Manag. 2008, 28, 1160-1171. [CrossRef]

90. Koel, T.M.; Arnold, J.L.; Bigelow, P.E.; Ruhl, M.E. Native Fish Conservation Plan: Environmental Assessment; U.S. Department of the Interior, National Park Service: Yellowstone National Park, WY, USA, 2010. Available online: https://parkplanning.nps.gov/projectHome.cfm?projectID=30504 (accessed on 10 June 2020).

91. U.S. Department of the Interior. NPS Management Policies 2006; National Park Service, U.S. Government Printing Office: Washington, DC, USA, 2006; ISBN 0-16-076874-8.

92. Kaeding, L.R. New climate regime started and further shaped the historic Yellowstone Lake cutthroat trout population decline commonly attributed entirely to nonnative lake trout predation. Aquat. Ecol. 2020, 54, 641-652. [CrossRef]

93. Detjens, C.R.; Voigt, W.; Voigt, J.; Koel, T.M. Fly fishing volunteers support native fish conservation in Yellowstone. Yellowstone Sci. 2017, 25, 82-84.

94. Trout Unlimited. Science Supporting Management of Yellowstone Lake Fisheries: Responses to Frequently Asked Questions; Wyoming Water Project, Trout Unlimited: Lander, WY, USA, 2014; Available online: http://wyomingtu.org/wp-content/uploads/2014/03/Science-Supporting-Managementof-Yellowstone-Lake-Fisheries.pdf (accessed on 10 June 2020).

95. Hansen, M.J.; Guy, C.S.; Bronte, C.R.; Nate, N.A. Life history and population dynamics. In Lake Charr Salvelinus Namaycush: Biology, Ecology, Distribution, and Management; Muir, A.M., Krueger, C.C., Hansen, M.J., Riley, S.C., Noakes, D.L.G., Eds.; Fish \& Fisheries Series; Springer: New York, NY, USA. (in press)

96. Morgan, L.A.; Shanks, W.C.; Lovalvo, D.A.; Johnson, S.Y.; Stephenson, W.J.; Pierce, K.L.; Harlan, S.S.; Finn, C.A.; Lee, G.; Webring, M.; et al. Exploration and discovery in Yellowstone Lake: Results from high-resolution sonar imaging, seismic reflection profiling, and submersible studies. J. Volcanol. Geotherm. Res. 2003, 122, 221-242. [CrossRef]

97. Bigelow, P.E.; Doepke, P.D.; Ertel, B.E.; Guy, C.S.; Syslo, J.M.; Koel, T.M. Suppressing non-native lake trout in Yellowstone Lake. Yellowstone Sci. 2017, 25, 53-59. Available online: https:/www.nps.gov/articles/ suppressing-non-native-lake-trout-to-restore-native-cutthroat-trout-in-yellowstone-lake.htm (accessed on 10 June 2020).

98. Gutowsky, L.F.G.; Romine, J.G.; Heredia, N.A.; Bigelow, P.E.; Parsley, M.J.; Sandstrom, P.T.; Suski, C.D.; Danylchuk, A.J.; Cooke, S.J.; Gresswell, R.E. Revealing migration and reproductive habitat of invasive fish under an active population suppression program. Conserv. Sci. Pract. 2020, 2, e119. [CrossRef]

99. Allen, M.S.; Hightower, J.E. Fish population dynamics: Mortality, growth, and recruitment. In Inland Fisheries Management in North America, 3rd ed.; Hubert, W.A., Quist, M.C., Eds.; American Fisheries Society: Bethesda, MD, USA, 2010; pp. 43-79.

100. Quist, M.C.; Pegg, M.A.; DeVries, D.R. Age and growth. In Fisheries Techniques, 3rd ed.; Alexander, A.V., Parrish, D.L., Sutton, T.M., Eds.; American Fisheries Society: Bethesda, MD, USA, 2012; pp. 677-731.

101. Guy, C.S.; Brown, M.L. Analysis and Interpretation of Freshwater Fisheries Data; American Fisheries Society: Bethesda, MD, USA, 2007.

102. Syslo, J.M. Demography of Lake Trout in Relation to Population Suppression in Yellowstone Lake, Yellowstone National Park. Master's Thesis, Montana State University, Bozeman, MT, USA, 2010.

103. Morris, W.F.; Doak, D.F. Quantitative Conservation Biology: Theory and Practice of Population Viability Analysis; Sinauer Associates: Sunderland, MA, USA, 2002.

104. Cambray, J.A. Impact on indigenous species biodiversity caused by the globalisation of alien recreational freshwater fisheries. Hydrobiologia 2003, 500, 217-230. [CrossRef]

105. Reinhart, D.P. Grizzly Bear Habitat Use on Cutthroat Trout Spawning Streams in Tributaries of Yellowstone Lake. Master's Thesis, Montana State University, Bozeman, MT, USA, 1990.

106. Kaeding, L.R.; Koel, T.M. Age, growth, maturity, and fecundity of Yellowstone Lake cutthroat trout. Northwest Sci. 2011, 85, 431-444. [CrossRef] 
107. Syslo, J.M.; Guy, C.S.; Koel, T.M. Feeding ecology of native and nonnative salmonids during the expansion of a nonnative apex predator in Yellowstone Lake, Yellowstone National Park. Trans. Am. Fish. Soc. 2016, 145, 476-492. [CrossRef]

108. Ripple, W.J.; Estes, J.A.; Schmitz, O.J.; Constant, V.; Kaylor, M.J.; Lenz, A.; Motley, J.L.; Self, K.E.; Taylor, D.S.; Wolf, C. What is a trophic cascade? Trends Ecol. Evol. 2016, 31, 842-849. [CrossRef]

109. Teisberg, J.E.; Haroldson, M.A.; Schwartz, C.C.; Gunther, K.A.; Fortin, J.K.; Robbins, C.T. Contrasting past and current numbers of bears visiting Yellowstone cutthroat trout streams. J. Wildl. Manag. 2014, 78, 369-378. [CrossRef]

110. Stott, W. Molecular Genetic Characterization and Comparison of Lake Trout from Yellowstone and Lewis Lakes, Wyoming; Research Completion Report for Project \#1443-IA-15709-9013; National Park Service, Yellowstone National Park: Mammoth, WY, USA, 2004; Available online: https:/www.researchgate.net/publication/ 331744804 (accessed on 10 June 2020).

111. Munro, A.R.; McMahon, T.E.; Ruzycki, J.R. Natural chemical markers identify source and date of introduction of an exotic species: Lake trout (Salvelinus namaycush) in Yellowstone Lake. Can. J. Fish. Aquat. Sci. 2005, 62, 79-87. [CrossRef]

112. Stapp, P.; Hayward, G.D. Estimates of predator consumption of Yellowstone cutthroat trout (Oncorhynchus clarkii bouvieri) in Yellowstone Lake. J. Freshw. Ecol. 2002, 17, 319-329. [CrossRef]

113. Koel, T.M.; Kerans, B.L.; Barras, S.C.; Hanson, K.C.; Wood, J.S. Avian piscivores as vectors for Myxobolus cerebralis in the Greater Yellowstone Ecosystem. Trans. Am. Fish. Soc. 2010, 139, 976-988. [CrossRef]

114. Koel, T.M.; Mahony, D.L.; Kinnan, K.L.; Rasmussen, C.; Hudson, C.J.; Murcia, S.; Kerans, B.L. Myxobolus cerebralis in native cutthroat trout of the Yellowstone Lake ecosystem. J. Aquat. Anim. Health 2006, 18, 157-175. [CrossRef]

115. Murcia, S.; Kerans, B.L.; Koel, T.M.; MacConnell, E. Myxobolus cerebralis (Hofer) infection risk in native cutthroat trout Oncorhynchus clarkii (Richardson) and its relationships to tributary environments in the Yellowstone Lake basin. J. Fish Dis. 2014, 38, 637-652. [CrossRef]

116. Murcia, S.; Kerans, B.L.; MacConnell, E.; Koel, T.M. Myxobolus cerebralis infection patterns in Yellowstone cutthroat trout after natural exposure. Dis. Aquat. Org. 2006, 71, 191-199. [CrossRef] [PubMed]

117. Murcia, S.; Kerans, B.L.; MacConnell, E.; Koel, T.M. Correlation of environmental attributes with histopathology of native Yellowstone cutthroat trout naturally infected with Myxobolus cerebralis. Dis. Aquat. Org. 2011, 93, 225-234. [CrossRef]

118. Alexander, J.D.; Kerans, B.L.; Koel, T.M.; Rasmussen, C. Context-specific parasitism in Tubifex tubifex in geothermally influenced stream reaches in Yellowstone National Park. J. N. Am. Benthol. Soc. 2011, 30, 853-867. [CrossRef]

119. Stewart, K.P. Use of Otolith Microchemistry to Identify Yellowstone Cutthroat Trout and Lake Trout Natal Origins and Movement Patterns in Yellowstone Lake, Wyoming. Master's Thesis, Montana State University, Bozeman, MT, USA, 2016.

120. Syslo, J.M.; Guy, C.S.; Arnold, J.L.; Koel, T.M.; Ertel, B.D. Standard Operating Procedures for Distribution Netting in Yellowstone Lake; 2010-2012 Final Report; USGS, Montana Cooperative Fishery Research Unit: Yellowstone National Park, WY, USA, 2014; Available online: https://www.researchgate.net/publication/339697733 (accessed on 10 June 2020).

121. Gresswell, R.E.; Heredia, N.A.; Romine, J.G.; Gutowsky, L.F.G.; Sandstrom, P.T.; Parsley, M.J.; Bigelow, P.E.; Suski, C.D.; Ertel, B.D. Identifying movement patterns and spawning areas of lake trout in Yellowstone Lake. Yellowstone Sci. 2017, 25, 66-69. Available online: https://www.nps.gov/articles/identifying-movementpatterns-and-spawning-areas-of-lake-trout-in-yellowstone-lake.htm (accessed on 10 June 2020).

122. Williams, J.R.; Guy, C.S.; Koel, T.M.; Bigelow, P.E. Targeting aggregations of telemetered lake trout to increase gillnetting suppression efficacy. N. Am. J. Fish. Manag. 2020, 40, 225-231. [CrossRef]

123. Simard, L.G.; Marsden, J.E.; Gresswell, R.E.; Euclide, M. Rapid early development and feeding benefits an invasive population of lake trout. Can. J. Fish. Aquat. Sci. 2019, 77, 496-504. [CrossRef]

124. Detjens, C.R.; Carim, K.J. Environmental DNA: A new approach to monitoring fish in Yellowstone National Park. Yellowstone Sci. 2017, 25, 26-27.

125. Roddewig, M.R.; Churnside, J.H.; Hauer, F.R.; Williams, J.; Bigelow, P.E.; Koel, T.M.; Shaw, J.A. Airborne lidar detection and mapping of invasive lake trout in Yellowstone Lake. Appl. Opt. 2018, 57, 4111-4116. [CrossRef] 
126. Food and Agriculture Organization of the United Nations. Report on the First Session of FAO Panel of Experts on Integrated Pest Control; FAO: Rome, Italy, 1968.

127. Dent, D. Integrated Pest Management; Chapman and Hall: New York, NY, USA, 1995.

128. Ehler, L.E. Integrated pest management (IPM): Definition, historical development and implementation, and the other IPM. Pest Manag. Sci. 2006, 62, 787-789. [CrossRef]

129. Flint, M.L.; Van den Bosch, R. Introduction to Integrated Pest Management; Plenum Press: New York, NY, USA, 1981. [CrossRef]

130. Peshin, R.; Bandral, R.S.; Zhang, W.; Wilson, L.; Dhawan, A.K. Integrated pest management: A global overview of history, programs, and adoption. In Integrated Pest Management: Innovation-Development Process, Peshin, R., Dhawan, A.K., Eds.; Springer: Dordrecht, The Netherlands, 2009; pp. 1-49.

131. Lechelt, J.D.; Bajer, P.G. Modeling the potential for managing invasive common carp in temperate lakes by targeting their winter aggregations. Biol. Invasions 2016, 18, 831-839. [CrossRef]

132. Weber, M.J.; Hennen, M.J.; Brown, M.L.; Lucchesi, D.O.; St. Sauver, T.R. Compensatory response of invasive common carp Cyprinus carpio to harvest. Fish. Res. 2016, 179, 168-178. [CrossRef]

133. Pearson, J.; Dunham, J.; Ryan Bellmore, J.; Lyons, D. Modeling control of common carp (Cyprinus carpio) in a shallow lake-wetland system. Wetlands Ecol. Manag. 2019, 27, 663-682. [CrossRef]

134. Sawyer, A.J. Prospects for integrated pest management of the sea lamprey (Petromyzon marinus). Can. J. Fish. Aquat. Sci. 1980, 37, 2081-2092. [CrossRef]

135. Christie, G.C.; Goddard, C.I. Sea lamprey international symposium (SLIS II): Advances in the integrated management of sea lamprey in the Great Lakes. J. Great Lakes Res. 2003, 29, 1-14. [CrossRef]

136. Johnson, N.S.; Yun, S.-S.; Thompson, H.T.; Brant, C.O.; Li, W. A synthesized pheromone induces upstream movement in female sea lamprey and summons them into traps. Proc. Natl. Acad. Sci. USA 2009, 106, 1021-1026. [CrossRef]

137. Ferreri, P.C.; Taylor, W.W.; Hayes, D.B. Evaluation of age-0 survival and its effect on lake trout rehabilitation in the Michigan waters of Lake Superior. J. Great Lakes Res. 1995, 21, 218-224. [CrossRef]

138. Cox, B.S.; Guy, C.S.; Fredenberg, W.A.; Rosenthal, L.R. Baseline demographics of a non-native lake trout population and inferences for suppression from sensitivity-elasticity analyses. Fish. Manag. Ecol. 2013, 20, 390-400. [CrossRef]

139. Bernhart, B.; Blackwood, C.; Gale, R.; Held, E. Yellowstone National Park Lake Trout Crisis: Report Prepared to Fulfill the Requirements of ME 404/ChE 411, Senior Design; College of Engineering, Montana State University: Bozeman, MT, USA, 2004. [CrossRef]

140. Gross, J.A.; Farokhkish, B.; Gresswell, R.E.; Webb, M.A.H.; Guy, C.S.; Zale, A.V. Techniques for Suppressing Invasive Fishes in Lacustrine Systems: A Literature Review; Final Report for Project RM-CESU H1200040001; National Park Service, Rocky Mountains Cooperative Ecosystem Studies Unit: Yellowstone National Park, WY, USA, 2010; Available online: http://files.cfc.umt.edu/cesu/NPS/MSU/2008/08Zale_YELL_trout\% 20embryos_lit\%20review.pdf (accessed on 10 June 2020).

141. Brown, P.J.; Guy, C.S.; Meeuwig, M.H. A comparison of two mobile electrode arrays for increasing mortality of lake trout embryos. N. Am. J. Fish. Manag. 2017, 37, 363-369. [CrossRef]

142. Doepke, P.D.; Koel, T.M.; Guy, C.S.; Poole, A.S.; Thomas, N.A.; Zale, A.V. Lake trout suppression alternatives to gillnetting. Yellowstone Sci. 2017, 25, 70-73. Available online: https://www.nps.gov/yell/learn/ys-25-1-laketrout-suppression-alternatives-to-gillnetting.htm (accessed on 10 June 2020).

143. Thomas, N.A. Evaluation of Suppression Methods Targeting Non-Native Lake Trout Embryos in Yellowstone Lake, Yellowstone National Park, Wyoming, USA. Master's Thesis, Montana State University, Bozeman, MT, USA, 2017.

144. Thomas, N.A.; Guy, C.S.; Koel, T.M.; Zale, A.V. In-situ evaluation of benthic suffocation methods for suppression of invasive lake trout embryos in Yellowstone Lake. N. Am. J. Fish. Manag. 2019, 39, 104-111. [CrossRef]

145. Poole, A.S.; Koel, T.M.; Thomas, N.A.; Zale, A.V. Suppression of invasive lake trout embryos by fish carcasses and sedimentation in Yellowstone Lake, Yellowstone National Park. N. Am. J. Fish. Manag. (under review).

146. Koel, T.M.; Arnold, J.L.; Bigelow, P.E.; Detjens, C.R.; Doepke, P.D.; Ertel, B.D.; MacDonald, D.J. Native Fish Conservation Program, Yellowstone National Park: Report 2015-2018; YCR-2019-04; National Park Service, Yellowstone Center for Resources: Yellowstone National Park, WY, USA, 2019. Available online: https: //home.nps.gov/yell/learn/upload/2015-2018-Fish-Report-_Web.pdf (accessed on 10 June 2020). 
147. Poole, A.S. Evaluation of Embryo Suppression Methods for Nonnative Lake Trout in Yellowstone Lake, Yellowstone National Park, Wyoming, USA. Master's Thesis, Montana State University, Bozeman, MT, USA, 2019.

148. Dwyer, W.P. Effect of lowering water temperature on hatching time and survival of lake trout eggs. Prog. Fish-Cult. 1987, 49, 175-176. [CrossRef]

149. Bronte, C.R.; Selgeby, J.H.; Saylor, J.H.; Miller, G.S.; Foster, N.R. Hatching, dispersal, and bathymetric distribution of age-0 wild lake trout at the Gull Island shoal complex, Lake Superior. J. Great Lakes Res. 1995, 21, 233-245. [CrossRef]

150. Mullins, M.S. Biology and Predator Use of Cisco (Coregonus artedi) in Fort Peck Reservior, Montana. Master's Thesis, Montana State University, Bozeman, MT, USA, 1991.

151. Cherry, T.L.; Shogren, J.F. Invasive species management for the Yellowstone Lake ecosystem: What do visitors think? Yellowstone Sci. 2001, 9, 10-15. Available online: https://www.nps.gov/yell/learn/upload/YS_ 9_2_sm.pdf (accessed on 10 June 2020).

152. National Park Service. Organic Act 16 USC 1-4. ch. 408, 39 Stat. 53511. 25 August 1916. Available online: https://www.nps.gov/parkhistory/online_books/fhpl/nps_organic_act.pdf (accessed on 10 June 2020).

153. Sax, D.F.; Stachowicz, J.J.; Brown, J.H.; Bruno, J.F.; Dawson, M.N.; Gaines, S.D.; Grosberg, R.K.; Hastings, A.; Holt, R.D.; Mayfield, M.M.; et al. Ecological and evolutionary insights from species invasions. Trends Ecol. Evol. 2007, 22, 465-471. [CrossRef] [PubMed]

154. Brown, J.H.; Sax, D.F. An essay on some topics concerning invasive species. Austral Ecol. 2004, $29,530-536$. [CrossRef]

155. Morgan, L.A.; Shanks, P.; Lovalvo, D.; Pierce, K.; Lee, G.; Webring, M.; Stephenson, W.; Johnson, S.; Finn, C.; Schulze, B.; et al. The floor of Yellowstone Lake is anything but quiet! New discoveries in lake mapping. Yellowstone Sci. 2003, 11, 15-30. Available online: https://www.nps.gov/yell/learn/upload/YS_11_2_sm.pdf (accessed on 10 June 2020).

156. Pianka, E.R. On r- and K-Selection. Am. Nat. 1970, 104, 592-597. [CrossRef]

157. Reznick, D.; Bryant, M.J.; Bashey, F. r- and K-selection revisited: The role of population regulation in life-history evolution. Ecology 2002, 83, 1509-1520. [CrossRef]

158. Sibly, R.M.; Barker, D.; Denham, M.C.; Hone, J.; Pagel, M. On the regulation of populations of mammals, birds, fish, and insects. Science 2005, 309, 607. [CrossRef]

159. Martin, N.; Olver, C.H. The lake charr, Salvelinus namaycush. In Charrs: Salmonid Fishes of the Genus Salvelinus; Balon, E., Ed.; Kluwer Boston, Inc.: Hingham, MA, USA, 1980; pp. 205-277.

160. Westley, P.A.H.; Fleming, I.A. Landscape factors that shape a slow and persistent aquatic invasion: Brown trout in Newfoundland 1883-2010. Divers. Distrib. 2011, 17, 566-579. [CrossRef]

161. Gunn, J.M. Spawning behavior of lake trout: Effects on colonization ability. J. Great Lakes Res. 1995, 21, 323-329. [CrossRef]

162. MacArthur, R.H.; Wilson, E.O. The Theory of Island Biogeography; Princeton University Press: Princeton, NY, USA, 1967.

163. Eklöv, P.; Svanbäck, R. Predation risk influences adaptive morphological variation in fish populations. Am. Nat. 2006, 167, 440-452. [CrossRef]

164. Suski, C.D.; Cooke, S.J. Conservation of aquatic resources through the use of freshwater protected areas: Opportunities and challenges. Biodivers. Conserv. 2007, 16, 2015-2029. [CrossRef]

165. Hedges, K.J.; Koops, M.A.; Mandrak, N.E.; Johannsson, O.E. Use of aquatic protected areas in the management of large lakes. Aquat. Ecosyst. Health Manag. 2010, 13, 135-142. [CrossRef]

166. Parker, S.R.; Mandrak, N.E.; Truscott, J.D.; Lawrence, P.L.; Kraus, D.; Bryan, G.; Molnar, M. Status and extent of aquatic protected areas in the Great Lakes. George Wright Forum 2017, 34, 381-393.

167. Ricker, W.E. Stock and recruitment. J. Fish. Res. Board Can. 1954, 11, 559-623. [CrossRef]

168. Hilborn, R.; Walters, C.J.; Ludwig, D. Sustainable exploitation of renewable resources. Ann. Rev. Ecol. Syst. 1995, 26, 45-67. [CrossRef]

169. Rose, K.A.; Cowan Jr, J.H.; Winemiller, K.O.; Myers, R.A.; Hilborn, R. Compensatory density dependence in fish populations: Importance, controversy, understanding and prognosis. Fish Fish. 2001, 2, $293-327$. [CrossRef]

170. Abrams, P.A. When does greater mortality increase population size? The long history and diverse mechanisms underlying the hydra effect. Ecol. Lett. 2009, 12, 462-474. [CrossRef] 
171. Hansen, M.J. Lake trout in the Great Lakes: Basinwide stock collapse and binational restoration. In Great Lakes Fisheries Policy and Management; Taylor, W.W., Ferreri, C.P., Eds.; Michigan State University Press: East Lansing, MI, USA, 1999; pp. 417-454.

172. Post, J.R. Resilient recreational fisheries or prone to collapse? A decade of research on the science and management of recreational fisheries. Fish. Manag. Ecol. 2013, 20, 99-110. [CrossRef]

173. Embke, H.S.; Rypel, A.L.; Carpenter, S.R.; Sass, G.G.; Ogle, D.; Cichosz, T.; Hennessy, J.; Essington, T.E.; Vander Zanden, M.J. Production dynamics reveal hidden overharvest of inland recreational fisheries. Proc. Natl. Acad. Sci. USA 2019, 116, 24676. [CrossRef] [PubMed]

174. Schröder, A.; van Leeuwen, A.; Cameron, T.C. When less is more: Positive population-level effects of mortality. Trends Ecol. Evol. 2014, 29, 614-624. [CrossRef]

175. Ellrott, B.J.; Marsden, J.E. Lake trout reproduction in Lake Champlain. Trans. Am. Fish. Soc. 2004, 133, 252-264. [CrossRef]

176. Jonas, J.L.; Claramunt, R.M.; Fitzsimons, J.D.; Marsden, J.E.; Ellrott, B.J. Estimates of egg deposition and effects of lake trout (Salvelinus namaycush) egg predators in three regions of the Great Lakes. Can. J. Fish. Aquat. Sci. 2005, 62, 2254-2264. [CrossRef]

177. Bajer, P.G.; Chizinski, C.J.; Silbernagel, J.J.; Sorensen, P.W. Variation in native micro-predator abundance explains recruitment of a mobile invasive fish, the common carp, in a naturally unstable environment. Biol. Invasions 2012, 14, 1919-1929. [CrossRef]

178. Bajer, P.G.; Sorensen, P.W. Recruitment and abundance of an invasive fish, the common carp, is driven by its propensity to invade and reproduce in basins that experience winter-time hypoxia in interconnected lakes. Biol. Invasions 2010, 12, 1101-1112. [CrossRef]

179. Claramunt, R.M.; Jonas, J.L.; Fitzsimons, J.D.; Marsden, J.E. Influences of spawning habitat characteristics and interstitial predators on lake trout egg deposition and mortality. Trans. Am. Fish. Soc. 2005, 134, 1048-1057. [CrossRef]

180. Fitzsimons, J.D.; Perkins, D.L.; Krueger, C.C. Sculpins and crayfish in lake trout spawning areas in Lake Ontario: Estimates of abundance and egg predation on lake trout eggs. J. Great Lakes Res. 2002, 28, 421-436. [CrossRef]

181. Riley, J.W.; Marsden, J.E. Predation on emergent lake trout fry in Lake Champlain. J. Great Lakes Res. 2009, 35, 175-181. [CrossRef]

182. Bolnick, D.I.; Ingram, T.; Stutz, W.E.; Snowberg, L.K.; Lau, O.L.; Paull, J.S. Ecological release from interspecific competition leads to decoupled changes in population and individual niche width. Proc. R. Soc. B Biol. Sci. 2010, 277, 1789-1797. [CrossRef]

183. Zipkin, E.F.; Kraft, C.E.; Cooch, E.G.; Sullivan, P.J. When can efforts to control nuisance and invasive species backfire? Ecol. Appl. 2009, 19, 1585-1595. [CrossRef] [PubMed]

184. Zipkin, E.F.; Sullivan, P.J.; Cooch, E.G.; Kraft, C.E.; Shuter, B.J.; Weidel, B.C. Overcompensatory response of a smallmouth bass (Micropterus dolomieu) population to harvest: Release from competition? Can. J. Fish. Aquat. Sci. 2008, 65, 2279-2292. [CrossRef]

185. Karatayev, V.A.; Kraft, C.E.; Zipkin, E.F. Racing through life: Maturation rate plasticity regulates overcompensation and increases persistence. Ecosphere 2015, 6, art203. [CrossRef]

186. Ohlberger, J.; Langangen, Ø.; Edeline, E.; Claessen, D.; Winfield, I.J.; Stenseth, N.C.; Vøllestad, L.A. Stage-specific biomass overcompensation by juveniles in response to increased adult mortality in a wild fish population. Ecology 2011, 92, 2175-2182. [CrossRef] [PubMed]

187. Hansen, M.J. Personnal Communication; U.S. Geological Survey, Great Lakes Science Center, Hammond Bay Biological Station: Millersburg, MI, USA, 2020.

188. Syslo, J.M. Dynamics of Yellowstone Cutthroat Trout and Lake Trout in the Yellowstone Lake Ecosystem: A Case Study for the Ecology and Management of Non-Native Fishes. Ph.D. Thesis, Montana State University, Bozeman, MT, USA, 2015.

189. Neumann, R.M.; Guy, C.S.; Willis, D.W. Length, weight, and associated structural indices. In Fisheries Techniques, 3rd ed.; Zale, A.V., Parrish, D.L., Sutton, T.M., Eds.; American Fisheries Society: Bethesda, MD, USA, 2012; pp. 637-676.

190. Wickham, H.; François, R.; Lionel, H.; Müller, K. dplyr: A Grammar of Data Manipulation, R Package Version 0.8.4; R Foundation for Statistical Computing: Vienna, Austria, 2020. 
191. R Core Team. R: A Language and Environment for Statistical Computing; R Foundation for Statistical Computing: Vienna, Austria, 2019.

192. Fox, J.; Weisberg, S. An R Companion to Applied Regression, 3rd ed.; Sage Publications, Inc.: Thousand Oaks, CA, USA, 2019. 